\title{
SUSTENTABILIDADE AMBIENTAL
}

\section{Organização:}

Afonso Rodrigues de Aquino Francisco Carlos Paletta

Thereza Cristina F. Camello

Tainá Pellegrino Martins Josimar Ribeiro de Almeida

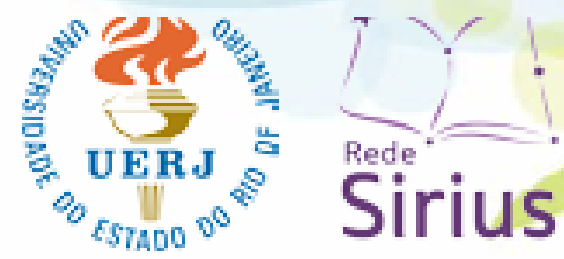



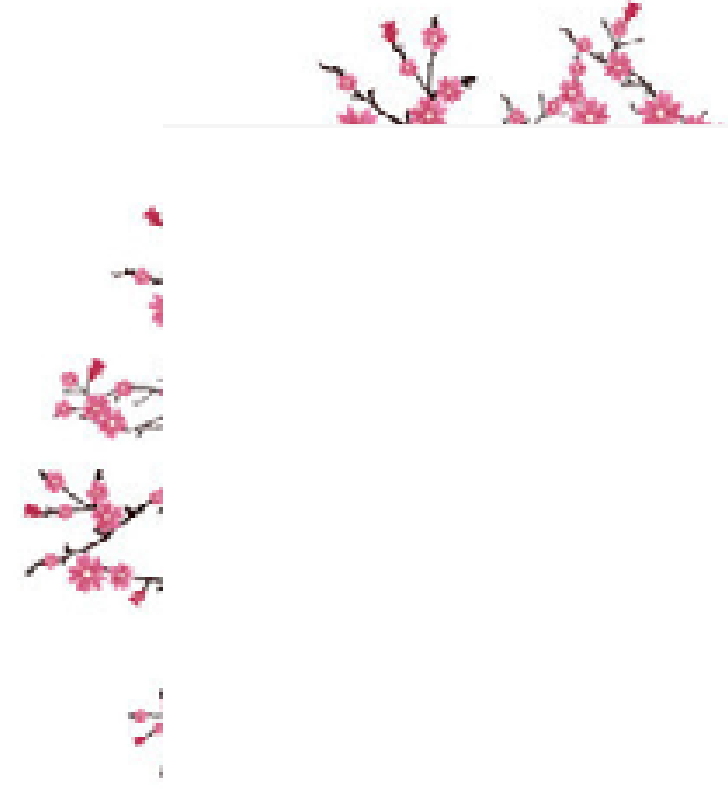

\author{
BIBLIOTECA DO OUERJ \\ Conselho Editorial \\ Fernando Rodrigues Altino (UERJ) \\ Júlio Nichioka (UERJ) \\ Oscar Rocha Barbosa (UERJ) \\ Rachid Saab (UERJ) \\ Thereza Camello (UERJ)
}

Conselho Executivo

Carlos Eduardo Silva (ESS)

Jackeline Bahe (ETFCS)

Pierre Morlin (PETROBRAS)

Manoel Rodrigues (UERJ)

Nilo Koschek (INPA)

Ricardo Fontenele (AMX)

Pauli Garcia Almada (UFF)

Ricardo Fermam (INMETRO)

Roberto Carvalho (UNESP)

Roberto de Xerez (UFRuRJ)

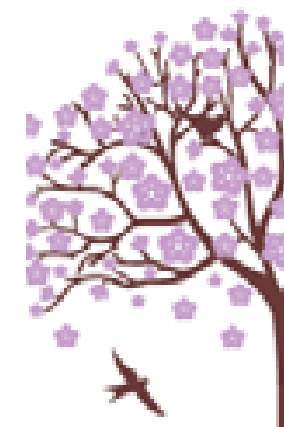




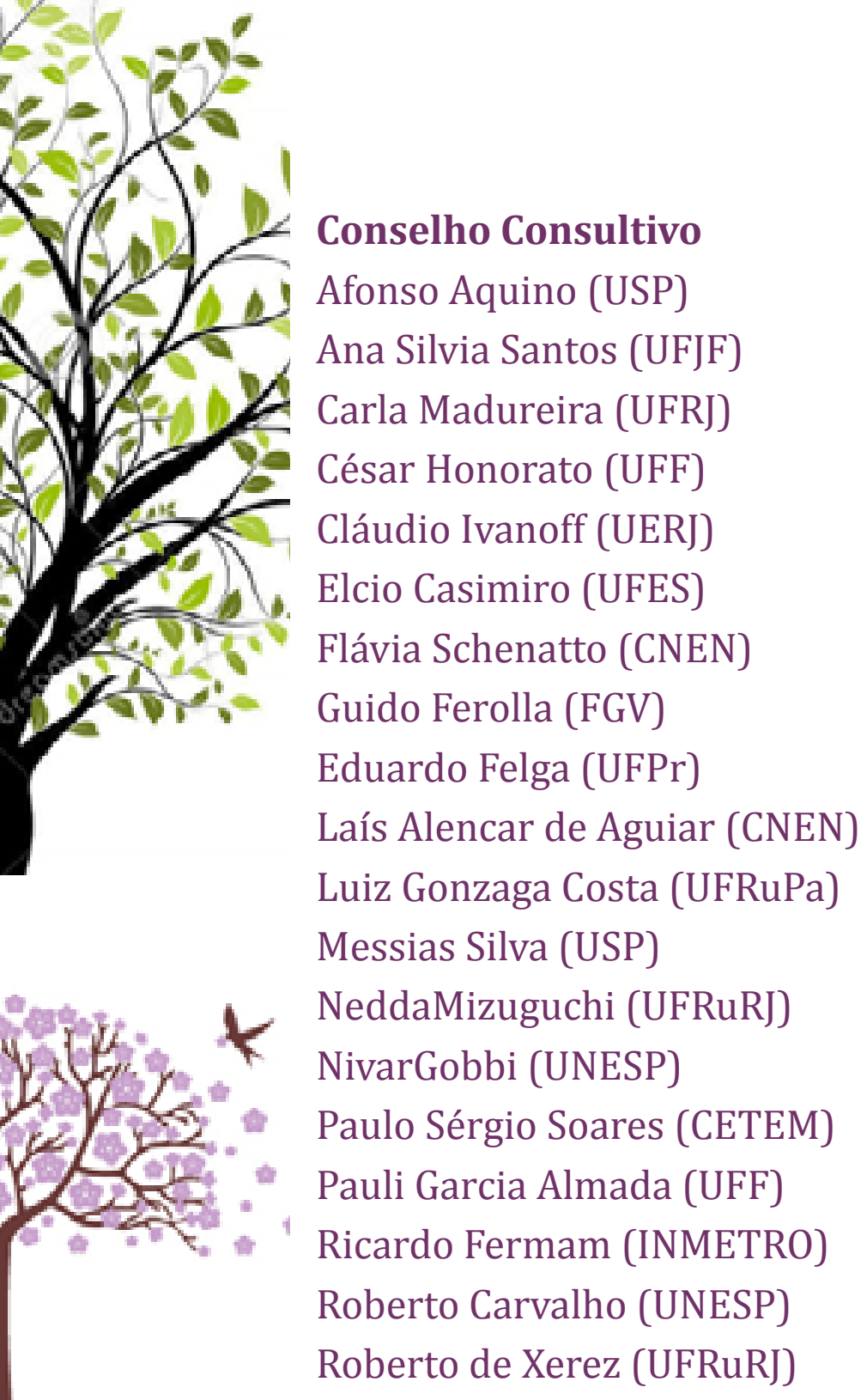




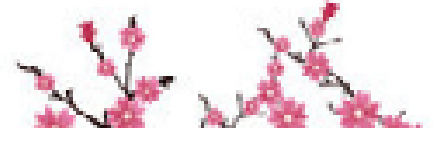

A BIBLIOTECA OUERJ é composta por diversos volumes

* em diferentes áreas temáticas. Representa o trabalho de Pesquisa, Magistério, Consultoria, Extensão e Auditoria de inúmeros profissionais de diversas instituições nacionais e extra-nacionais. O objetivo da biblioteca é ser útil como instrumentação e base epistemológica dos Graduandos, Pós-graduandos e profissionais das áreas pertinentes aos temas publicados. Por ser um material didá$\Rightarrow$ tico público poderá ter uso público especialmente para treinamento, formação acadêmica e extensionista de alunos e profissionais.

Evidentemente que cada caso da BIBLIOTECA OUERJ deve ser encarado dentro de um contexto a que foi inicialmente proposto. Especialmente deve-se levar em conta as limitações vigentes do estado d'arte, das circunstancias e da finalidade inicial a que foi proposta. As derivações e extrapolações podem ser adotadas desde que não se deixe de vislumbrar sempre, estes limites de escopo inicial que norteou estes trabalhos.

NósdoOUERJ,agradecemosespecialmenteaosautores, atodos os profissionais que compõem os Conselhos Editoriais, Executivos e Consultivo do OUERJ. Agradecimento especial a REDE SIRIUS e a Pro ReitoriadeExtensãoeCulturadaUERJquepossibilitaestapublicação.

\section{Diretoria do OUERJ}

\section{,}
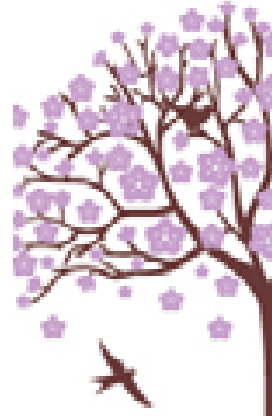


\section{SUMÁRIO}

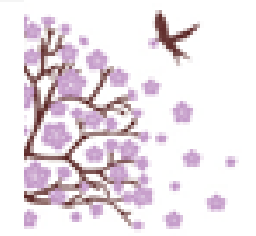

PREFÁCIO

INTRODUÇÃO

12

1. ENERGIA E SUSTENTABILIDADE 14

1.1 PRIMEIRA REVOLUÇÃO INDUSTRIAL 14

1.2 SEGUNDA REVOLUÇÃO INDUSTRIAL 15

1.3 TERCEIRA REVOLUÇÃO INDUSTRIAL 16

1.4 SUSTENTABILIDADE E DESENVOLVIMENTO 17

1.5 SUSTENTABILIDADE E GERAÇÃO DE ENERGIA 19

1.6 DESENVOLVIMENTO DA ENERGIA NO DECORRER DA EVOLUÇÃO HUMANA

1.7 A CHINA JÁ CONTRIBUÍA DIVERSIFICANDO A ESTRUTURA ENERGÉTICA ANTES DA ERA DO CAPITALISMO OCIDENTAL

2. FONTES DE ENERGIA ALTERNATIVA 26

2.1 ENERGIA HIDRELÉTRICA 26

2.2 BIOMASSA 28

2.3 ENERGIA SOLAR

2.4 ENERGIA EÓLICA

29

2.5 ENERGIA GEOTÉRMICA

31

2.6 ENERGIA DOS OCEANOS

2.7 GÁS NATURAL

2.8 ENERGIA NUCLEAR

2.9 SUSTENTABILIDADE E DESENVOLVIMENTO ENERGÉTICOS

3. DIMENSÕES DE DESENVOLVIMENTO SUSTENTÁVEL

3.1 DIMENSÃO AMBIENTAL

31

3.2 DIMENSÃO SOCIAL

32

34

35

39

44

46

47

3.3 DIMENSÃO ECONÔMICA

48 
3.4 DIMENSÃO INSTITUCIONAL

4. AQUECIMENTO GLOBAL E SUSTENTABILIDADE AMBIENTAL

4.1 PROTOCOLO DE KYOTO

* 4.2 CONFERÊNCIA DE BALI

4.3 REDUÇÃO DE EMISSÕES DE GASES DE EFEITO ESTUFA

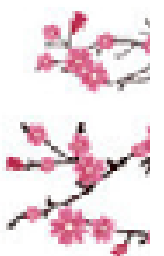

4.4 CRÉDITOS DE CARBONO

4.5 ÁGUA - ABASTECIMENTO E ESCASSEZ

5. EFLUENTES GASOSOS

5.1 MONÓXIDO DE CARBONO

5.2 DIÓXIDO DE ENXOFRE

5.3 DIÓXIDO DE NITROGÊNIO

$\Rightarrow$

8

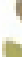

5.4 HIDROCARBONETOS E OUTROS COMP. ORGÂNICOS VOLÁTEIS

5.5 OZÔNIO (O3) E OUTROS OXIDANTES FOTOQUÍMICOS

5.6 MATERIAL PARTICULADO

6. EFLUENTES LÍQUIDOS

6.1 EFLUENTE LÍQUIDO INDUSTRIAL

6.2 EFLUENTE LÍQUIDO DOMÉSTICO

6.3 REUTILIZAÇÃO DE EFLUENTES LÍQUIDOS

7. RESÍDUOS SÓLIDOS

7.1 SUSTENTABILIDADE E RESÍDUOS SÓLIDOS

7.2 AÇÕES SUSTENTÁVEIS

7.3 RESÍDUOS INDUSTRIAIS

7.4 RECICLAGEM DE ELETRO-ELETRÔNICO

7.5 RESÍDUOS HOSPITALARES OU DE SERVIÇO DE SAÚDE

7.6 RECICLAGEM DE LÂMPADAS FLUORESCENTES

7.7 REJEITOS RADIOATIVOS

7.8 ATERRO SANITÁRIO

7.9 BIORREMEDIAÇÃO

7.10 COMPOSTAGEM

8. AGRICULTURA E SUSTENTABILIDADE

8.1 AGROINDÚSTRIA 
8.2 AGROINDÚSTRIA SUSTENTÁVEL

94

8.3 SISTEMA DE PLANTIO DIRETO E AGRICULTURA ORGÂNICA

9. SUSTENTABILIDADE EMPRESARIAL

9.1 SUSTENTABILIDADE EMPRESARIAL OU INDUSTRIAL

9.2 INICIATIVAS DE SUSTENTABILIDADE EMPRESARIAL NO BRASIL

9.3 ECONOMIA SUSTENTÁVEL

9.4 INDICADORES DE SUSTENTABILIDADE

9.5 SISTEMA DE INDICADORES DE SUSTENTABILIDADE

9.6 INDICADOR DE CONTROLE DE SUSTENTABILIDADE

9.7 BARÔMETRO DA SUSTENTABILIDADE

9.8 APLICAÇÕES SUSTENTÁVEIS

10. SUSTENTABILIDADE E EDUCAÇÃO AMBIENTAL

10.2 A PSICOLOGIA COMO UM SUPORTE

PARA A EDUCAÇÃO AMBIENTAL

140

10.3 PESQUISA DA ASSOCIAÇÃO AMERICANA DE PSICOLOGIA (APA) 141
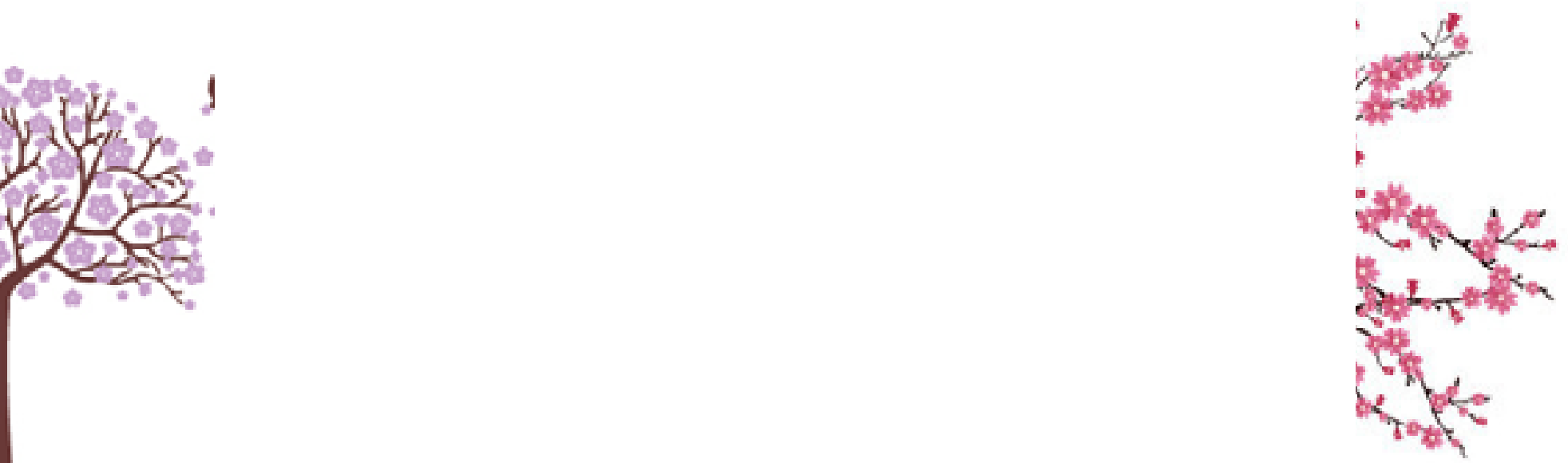


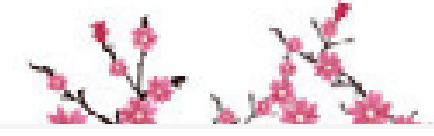

\section{PREFÁCIO}

0 termo desenvolvimento sustentável foi apresentado no relatório Nosso Futuro Comum de 1987, tendo como diretriz a ideia de um desenvolvimento que atenda as necessidades das gerações presentes, sem comprometer a habilidade das gerações futuras de suprir as suas próprias necessidades. O desenvolvimento sustentável é conhecido na interação entre três pilares: o pilar social, o pilar econômico e o pilar ambiental. A economia verde deve ser uma ferramenta para o desenvolvimento sustentável e da erradicação da pobreza. O desafio apresentado diante de nós é o de pensar um novo modelo de desenvolvimento que seja ambientalmente responsável, socialmente justo e economicamente viável. A energia e os problemas que envolvem o seu consumo se tornaram significativos no âmbito global, não sendo mais possível se manter alheio aos efeitos da exploração predatória e descontrolada. A proposta deste trabalho é discutir e propiciar novos debates que levem ao consumo sustentável e ao desenvolvimento econômico da sociedade. Nosso objetivo é contribuir com contínuo aprimoramento de profissionais que atuam na área de energia, meio ambiente e sustentabilidade, tornando-os cada vez

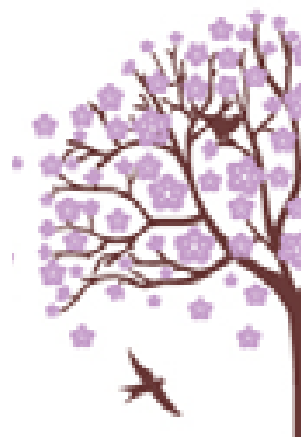


mais engajados e qualificados nas suas ações comprometidos com desenvolvimento econômico sustentável do planeta. Este livro foi idealizado e realizado dentro da disciplina de pós-graduação Análise de Sistemas de Gestão Ambiental - TNM 5790 - do Programa de Pós-Graduação do Instituto de Pesquisas Energéticas e Nucleares da Universidade de São Paulo. Mérito dos alunos, o livro foi organizado pelos docentes Afonso Aquino e Josimar Almeida com o auxílio do Prof. Franciso Paletta que, por não ser titular da disciplina, atuou como um ombudsman.

\section{Os Organizadores}

Afonso Rodrigues de Aquino

Francisco Carlos Paletta Josimar Ribeiro de Almeida Thereza Cristina F. Camello Tainá Pellegrino Martins
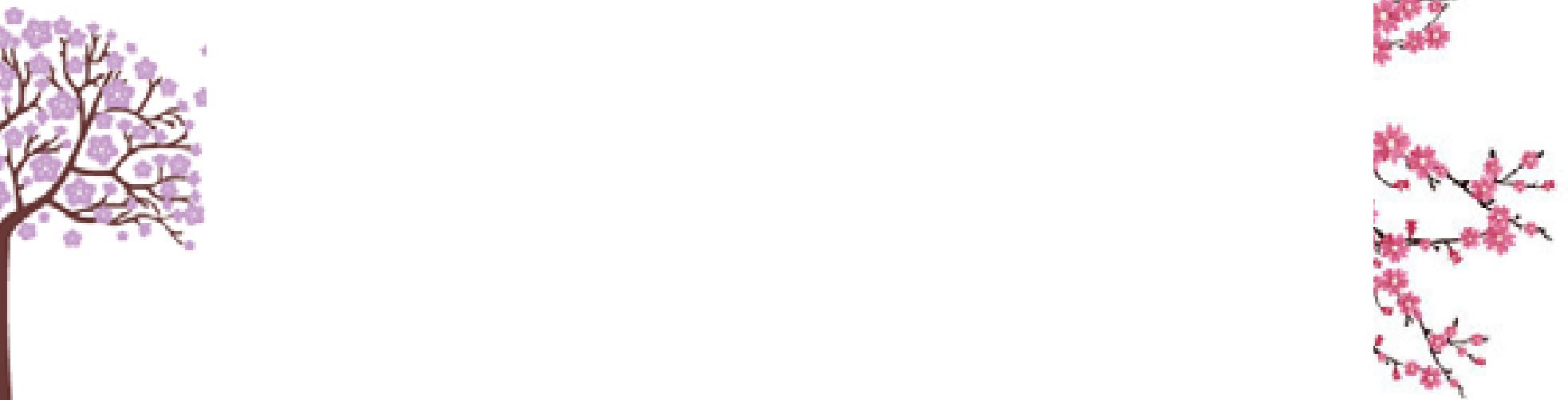


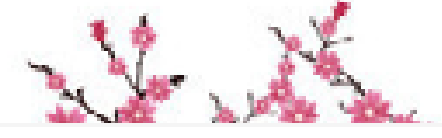

Observando o passado vimos que o trinômio: Energia, Desenvolvimento e Degradação, sempre se fizeram presentes durante milhares de anos em todas as grandes civilizações. A lógica da época era muito simples, e assemelha-se em muitos aspectos com a que utilizamos até hoje. 0 desenvolvimen$\geqslant$ to era pautado na busca incessante de uma fonte energética que gerasse o custo benefício mais atraente, e isso era tudo, não haviam outras preocupações. A maior parte dessa energia era oriunda de fontes não-renováveis como o carvão vegetal, largamente utilizado nos primórdios de nossa civilização. O desenvolvimento sustentável, a prevenção e controle integrados da poluição, são palavras-chave para uma nova abordagem, visando a proteção ambiental. Atualmente se considera indissociável do conceito de produtividade, a minimização de efluentes e a racionalização do consumo de matérias-primas. Ao organizar este trabalho nossa proposta é discutir temas relevantes que estão presentes na agenda de todo o setor produtivo, governo e universidades com objetivo de apresentar possíveis caminhos que possam garantir o desenvolvimento econômico, a geração de riqueza, a distribuição de renda e ao mesmo tempo permitir a sustentabilidade do planeta. Apresentamos

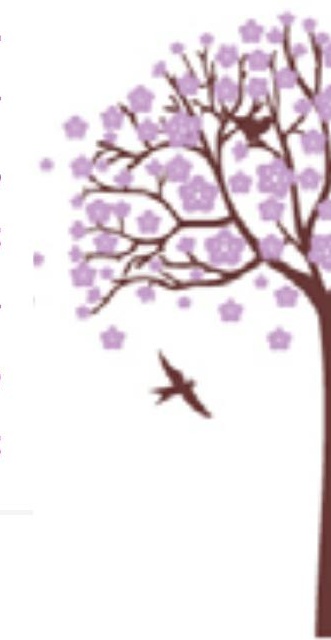


temas de significativa importância no debate da sustentabilidade ambiental como Energia e Sustentabilidade, Energias Alternativas, Dimensões de Desenvolvimento Sustentável, Aquecimemento Global e Sustentabilidade Ambiental, Efluentes Líquidos e Gasosos, Resíduos Sólidos, Agricultura e Sustentabilidade, Sustentabilidade Empresarial, Sustentabilidade e Educação Ambiental. Cientes da nossa responsabilidade como educadores, na formação de profissionais que deverão liderar e conduzir os destinos deste país para os próximas décadas, temos o compromisso de criar um terreno fértil para o debate em torno da sustentabilidade ambiental e seus impactos para vida no planeta.

Prof. Dr. Josimar Ribeiro de Almeida Comitê Científico do Observatório Urbano(ONU-UERJ) Professor da Universidade do Estado do Rio de Janeiro
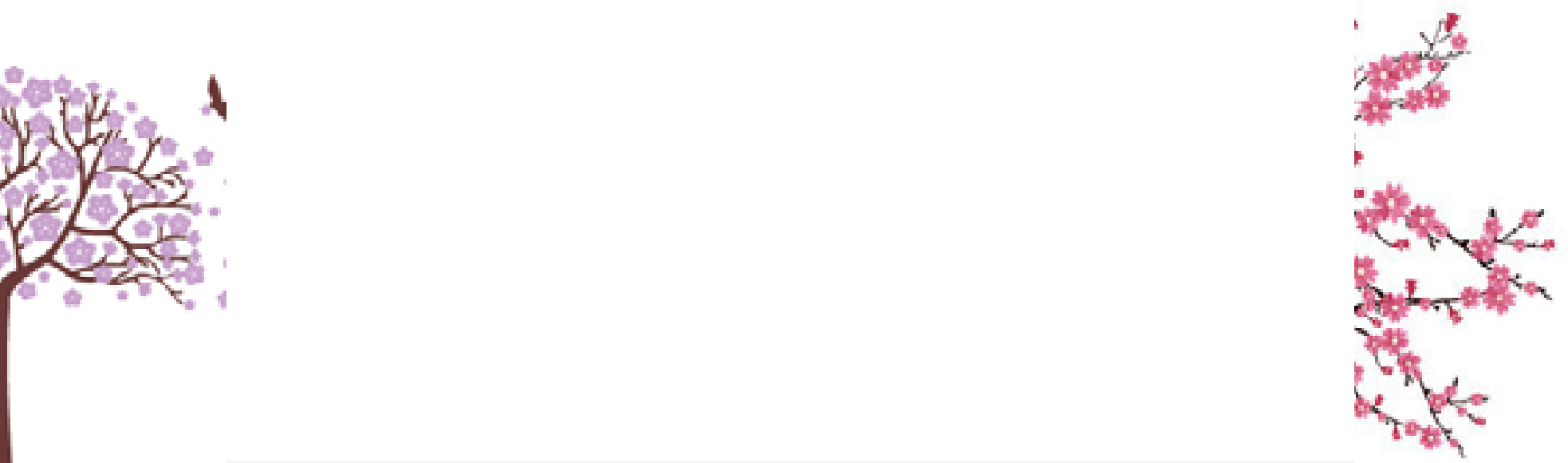


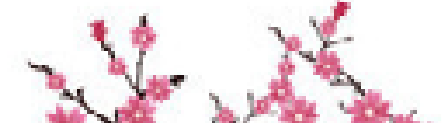

\section{Primeira Revolução Industrial}

Foi a primeira grande transformação sócio-econômica-ambiental de impacto relevante. Teve na Inglaterra o seu marco inicial [1], e o país assumiu a partir daí, a liderança do mundo moderno. * Com a ampla utilização do conhecimento científico foi possível ter início a fabricação de bens de produção e consumo em escala industrial. 0 grande marco da revolução industrial foi a máquina à vapor de James Watt (1769). A energia originada pelo vapor foi largamente utilizada na extração de minérios, na indústria têxtil e no grande avanço em relação aos meios de transporte de pessoas e mercadorias, reduzindo a necessidade da força muscular. A escuna é substituída pelo navio a vapor e os vagões que antes eram puxados por cavalos, pelas locomotivas que também se movimentavam com a energia do vapor [2,3]. Com o advento de Watt, a Inglaterra passou a depender ainda mais da importação de madeira de outros países. Várias florestas européias foram dizimadas durante essa época, pois a procura pelo carvão vegetal era intensa. Diante de tal quadro, a Inglaterra optou por substituir o uso do carvão vegetal pelo mineral. Outro fato ocorrido que merece destaque é a morte de milhares

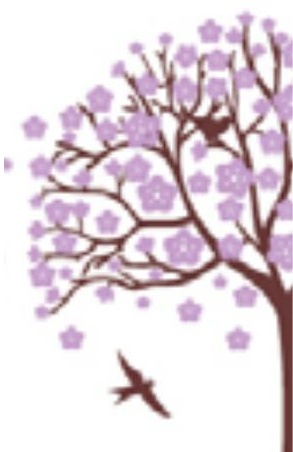


de baleias, pois o óleo extraído era utilizado para iluminar as casas e ruas da Europa [1,2]. Durante esse período a classe operária sofreu um grande empobrecimento. Um fato interessante é que durante o século XVIII o suprimento de água de Londres, em parte, era feito com o uso da energia das marés (maré motriz) [4].

\section{Segunda Revolução} Industrial

A Segunda Revolução Industrial ocorreu entre 1860 e a I Guerra Mundial. 0 petróleo começou a competir com o carvão e a eletricidade foi efetivamente utilizada pela primeira vez, criando uma nova fonte de energia para operar motores, iluminar cidades e proporcionar comunicação instantânea entre as pessoas. A exemplo da revolução do vapor, o petróleo, a eletricidade e as invenções que os acompanharam na Segunda Revolução Industrial continuaram a transferir a carga da atividade econômica do homem para a máquina [4]. A industrialização atingiu vários outros países europeus como a Alemanha, Itália e França. Na América os Estados Unidos e do outro lado do mundo o Japão. Em 1878 foi utilizada a prensa acionada por uma máquina a vapor de fonte solar. Surgem novos produtos como o plástico e o aço, sendo esse último o substituto do ferro. Em 1888 foi posto em funcionamento nos Estados Unidos o primeiro catavento para gerar energia elétrica. Em 1878 é construída a primeira hidrelétrica do mundo. Em 1909

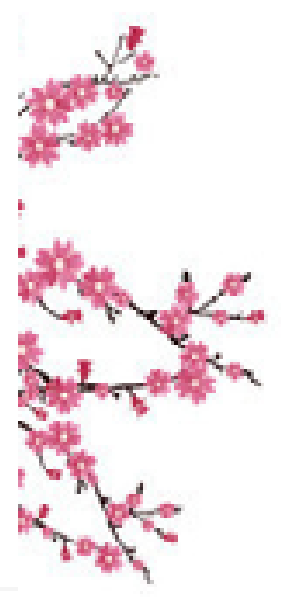




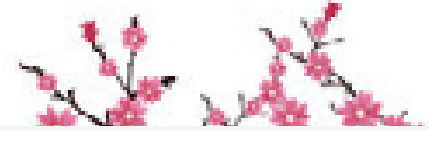

é criada a linha de montagem e

- a produção em série, por Henry Ford. Novas fontes energéticas surgem para juntar-se às outras já utilizadas em larga escala (lenha e carvão mineral). No final do século XIX surge a eletricidade, e em meados do século

: XX o mais versátil dos combustíveis fósseis, o petróleo $[2,3,5]$. Há um aumento acentuado da poluição do ar, da água e do solo e a devastação das áreas de exploração do carvão mineral e do petróleo. Iniciativas para o controle destes impactos começam a ser desenvolvidas. Em 1913 é desenvolvida no Egito uma bomba de irrigação com captadores solares planos. Em 1931 são inventadas as células fotovoltaicas e em 1951 já existem 50 mil aquecedores solares em Miami, nos EUA [1, 3].
Terceira Revolução Industrial

Muito mais dependente de recursos energéticos, no período pós-II Guerra Mundial a partir da década de 50, surgem complexos industriais e empresas multinacionais. As indústrias químicas e eletrônicas crescem. Os avanços da automação, da informática e da engenharia genética são incorporados ao processo produtivo, que depende cada vez mais de alta tecnologia e de mão-de-obra especializada. A informatização substitui, em alguns casos, a mão-de-obra humana, contribuindo para a eliminação de inúmeros postos de trabalho [4]. A preocupação com o meio ambiente começa a ganhar espaço nas mesas de negociação, pois os efeitos de anos de degradação já são sentidos pela população

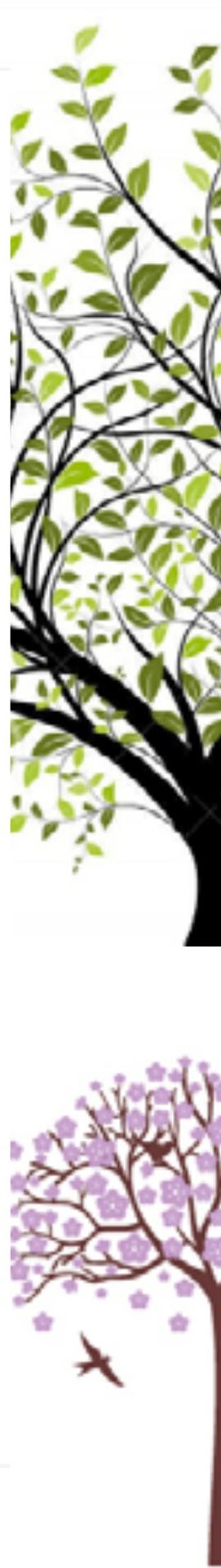


mundial, como: efeito estufa, chuva ácida e mudanças climáticas. Nesse período entra em cena a energia Nuclear, mas precisamente na década de 50 quando o primeiro reator nuclear de potência no mundo, denominado EBR1 , entrou em operação gerando 0,2 MW elétricos em dezembro de 1951, em Arco, Idaho, EUA [6]. Inicialmente criada para fins militares, agora vista, como uma fonte energética capaz de gerar eletricidade provocando um impacto mínimo ao meio ambiente.

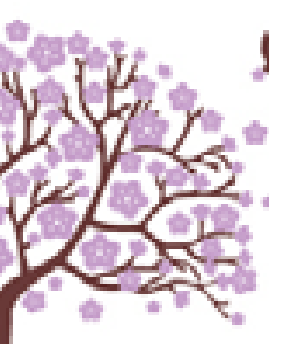

\section{Sustentabilidades e}

\section{Desenvolvimento das Próxi-} mas Décadas

$\mathrm{Na}$ Pré-História estima-se que o homem nômade consumia $5 \mathrm{mil} \mathrm{kcal/dia,} \mathrm{enquanto}$ o agricultor após a revolução neolítica em 5000 a.C. passa a usar 10 mil kcal/dia. Com a urbanização desencadeada ao final da Idade Média (1400 d.C.) e a consequente ocupação de vastas florestas europeias o consumo elevou-se para 26 mil kcal/ dia. Em plena era industrial, por volta de 1875, o uso intensivo do carvão permitiu atingir o nível médio de $77 \mathrm{mil} \mathrm{kcal} / \mathrm{dia}$. Estes números representam um crescimento de 15 vezes nos últimos 12 mil anos, um aumento exponencial com o tempo [2]. 0 petróleo tende a permanecer como a principal fonte energética, embora com diminuição da sua participação ( 30\%). Haverá um aumento da participação do gás natural e carvão. Há projetos em andamento a nível mundial, visando aumentar significativamente a participação da energia
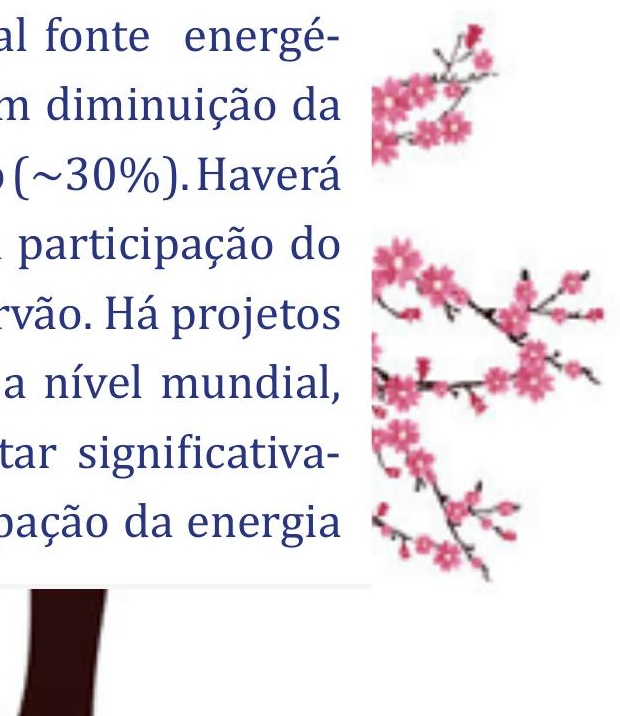
eles nos deixaram. Cabe a nós decidirmos hoje, o tipo de desenvolvimento e qual a herança que ele nos permitirá deixar para as gerações futuras.

\section{Sustentabilidade e Geração de Energia}

A energia está presente de forma essencial em nossas vidas. As decisões tomadas hoje em relação a ela influenciam nosso futuro, seu uso afeta, o meio ambiente trazendo mudanças socioculturais e demográficas significativas. Não há como gerar energia sem agredir o meio ambiente de alguma forma . A energia não pode ser criada, mas pode ser transferida de uma forma para outra por meio de processos de conversão, e pode ser encontrada em dois estados extremos: potencial e cinética $[7,8]$.
A matriz energética é resultado do balanço energético consolidado que mostra as interrelações entre oferta, transformação e uso final da energia. 0 estudo da matriz energética é um importante instrumento no planejamento do desenvolvimento e por consequência, para as pretensões do desenvolvimento sustentável. A energia pode ser encontrada em forma de energia atômica ou nuclear, química, elétrica, térmica, mecânica ou magnética [7] sendo suas principais fontes: hidroelétrica, solar direta, biodigestores eólicos, marítimos, geotérmicos e magneto-hidrodinâmica [9]. As fontes primárias de energia são divididas em duas categorias: as renováveis e as não-renováveis e pode-se também dividi-las conforme a fonte de

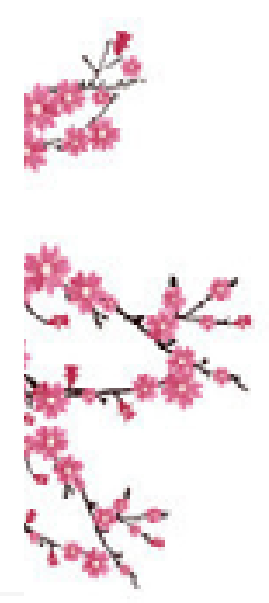




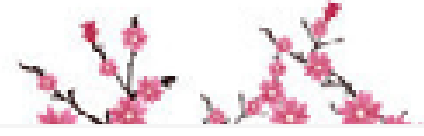

tes, já que emitem grandes quantidades de gases na atmosfera, causando problemas de saúde e ambientais [10]. As instalações que utilizam combustíveis fósseis (como carvão, petróleo e gás

natural) não produzem apenas energia, mas também grandes quantidades de vapor de água e de dióxido de carbono (CO2), gás que é um dos principais responsáveis pelo efeito estufa do planeta, além disso, são emitidos outros gases nocivos como os óxidos de azoto (NOx), de enxofre (SO2) e os hidrocarbonetos (HC). Estes gases provocam modificações ambientais graves e sua concentração na atmosfera causa a poluição das cidades, a formação de chuvas ácidas, de névoa (denominada smog foto- químico) [11]. As energias renováveis são aquelas cujas fontes não se esgotam, ou seja, se renovam. É importante ressaltar que nem todas as maneiras de aproveitar as fontes renováveis de energia são sustentáveis [10]. Avaliando-se os recursos naturais existentes, são grandes as alternativas energéticas. Há atualmente grandes reservas de petróleo em formas não convencionais. 0 gás natural possui grandes reservas e, o carvão, é o combustível mais importante na geração de energia elétrica no mundo, sendo estas as três principais fontes da matriz energética mundial. Existem grandes reservas de urânio e tório, sendo o segundo, pouco utilizado [12]. Atualmente os combustíveis fósseis geram $78 \%$ da energia mundial, sendo o pe-

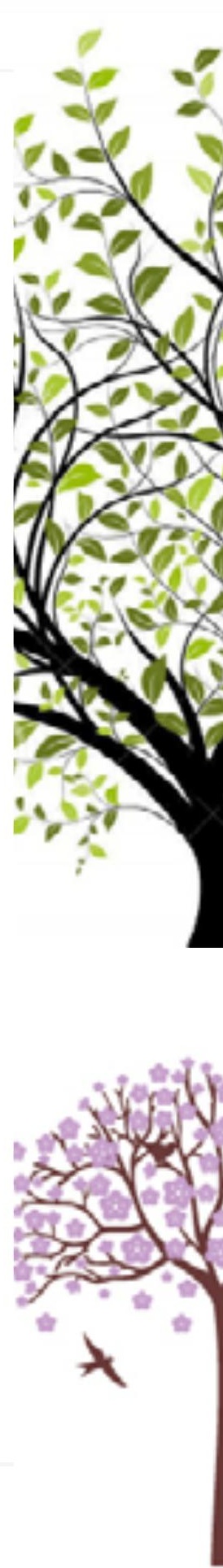


tróleo a principal fonte da matriz energética mundial [13], e o alto custo de implementação de fontes alternativas ainda é um obstáculo à sua utilização [8]. Um aspecto que deve ser analisado na escolha da fonte utilizada na produção de energia (fase responsável pela maior parcela dos danos causados pelo uso da energia) é o impacto ambiental ocasionado por ela na geração e no seu transporte, além das vantagens e desvantagens do uso de cada uma delas [13]. A demanda de energia no mundo cresce a cada ano e os padrões de produção e consumo atuais estão destruindo o meio ambiente. É preciso passar a depender mais de recursos renováveis além de ter uma utilização responsável da energia e conservação energética com sistemas mais eficientes para que se possa atingir um desenvolvimento sustentável, reduzindo gastos com energia e também os impactos causados por novas centrais geradoras [8]. o Desenvolvimento da Energia no Decorrer da Evolução Humana

Nos primórdios de sua existência a única fonte de energia que o homem dispunha para a sua sobrevivência era a força muscular. Passado esse período, o fogo passou a ser utilizado (50.000 anos a.C.), mas o homem só desenvolveu a capacidade de acendê-lo 40.000 anos depois. Esse episódio descreve o primeiro avanço tecnológico no qual a humanidade foi submetida. O período que vai de 10.000 anos a.C. até 5.000 anos a.C. foi marcado pelo uso da força de tração ani-

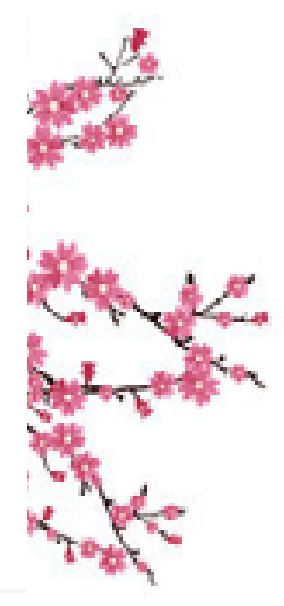




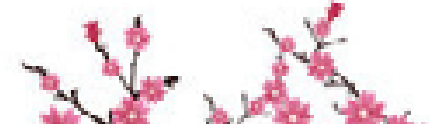

mal na agricultura [1], essa era . capaz de produzir uma potência aumentada de no mínimo um fator quatro vezes maior [2], quando comparado a força humana. Há cerca de 6.000 anos a.C. o asfalto era usado pelos Sumérios, e 4.000 anos depois o petróleo crú foi utilizado como combustível [3]. Os ventos na navegação a vela foram um aproveitamento energético importante, que atingiu o seu ápice com o povo fenício no segundo milênio antes de Cristo. O Mar Mediterrâneo, o Mar Vermelho e o Golfo Pérsico constituem importantes meios para o transporte marítimo de cargas na antiguidade [2]. Em 1.700 a. C. a energia dos ventos era utilizada para bombear água na Pérsia e em 600 a C. na movimentação dos moinhos

para irrigação na Babilônia [4]. Os gregos que durante muito tempo tiveram domínio sobre o comércio e a navegação nas margens setentrionais do mediterrâneo, enfrentaram grandes dificuldades em suprir as suas cidades com alimentos e lenha do seu próprio território. A madeira era utilizada em grande escala nos estaleiros e na fundição de metais, a sua escassez, juntamente com outros fatores como, a dificuldade em usar a energia hidráulica (devido às variações climáticas), contribuíram para o seu declínio [2]. Durante o Império Romano (31 a.C. até 410 d.C.) a Península Ibérica e a Espanha tiveram as suas florestas dizimadas para que a madeira fosse utilizada em grande escala, na fundição de metais para a confecção de armas [2].

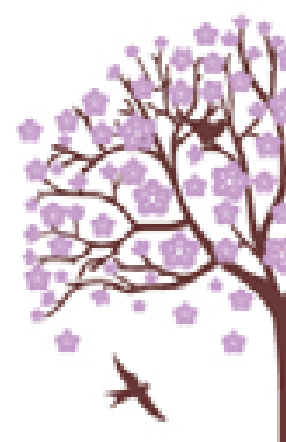




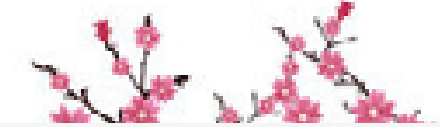

- na o gás também era utilizado para a iluminação, manufatura

1 de dutos de bambu e em perfuações de até 1000 metros [4]. $\underbrace{}_{4}$ Durante a Idade Média, o uso da energia baseava-se nos bioconversores (lenha, tração animal) e fontes renováveis como * a hidráulica e ventos e marés. Durante o século X são encontrados os primeiros registros do uso da energia das marés [2, 4]. No ano de 1276 é documentada a existência da primeira indústria de papel operando por energia hidráulica. Já no século XIV, 25 metros cúbicos de madeira (cubos de aproximadamente 3 $\mathrm{m})$ eram queimados para obter $50 \mathrm{~kg}$ de ferro [1]. A lenha e o carvão vegetal eram intensamente utilizados, para cocção de alimentos e padarias, aquecimento, olarias, forjas, manufa-

(n)

turas de vidros. Tal era a devastação florestal para estes usos e também para expansão das áreas de agricultura, construção civil, estaleiros que a Europa teve sérias dificuldades com o suprimento de madeira e lenha. Porque várias áreas florestais da região forma dizimadas [2].

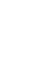

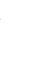


elétrica por meio da instalação de turbinas em rios represados ou não. Mesmo sendo uma fonte limpa, não está livre de impactos ambientais [12]. A produção deste tipo de energia é dependente da chuva. Quando chove abundantemente, a contribuição destas centrais atinge os $40 \%$, e, nos anos mais secos, apenas $20 \%$ da energia total consumida provém dos recursos hídricos [15]. Uma das vantagens dessa fonte é a versatilidade de configurações, permitindo desde micro-centrais até grandes hidrelétricas [13], além de produzir uma energia barata e limpa emitindo pouco carbono na atmosfera [16]. Os impactos variam de acordo com o tipo e tamanho da usina. As grandes impactam a fauna e a flora com o alagamento de grandes áreas, afetam o paisagismo, assoreamento dos reservatórios e perda de recursos minerais nas áreas alagadas, além da emissão degases do efeito estufa. As PCH's (Pequenas Centrais Hidrelétricas) apresentam impactos muito pequenos [13]. Essa fonte pode ser afetada pelo aquecimento global, reduzindo seu potencial com o passar do tempo [16]. A energia hidráulica é convertida em energia mecânica. Ao contrário das demais fontes renováveis, representa uma parcela significativa da matriz energética mundial e possui tecnologias de aproveitamento devidamente consolidadas. Embora a energia hidráulica ocupe uma posição de destaque na produção de energia elétrica no Brasil com 79\% de toda a energia elétrica gerada no País, representa por cerca de 17\% da produção mundial [17].
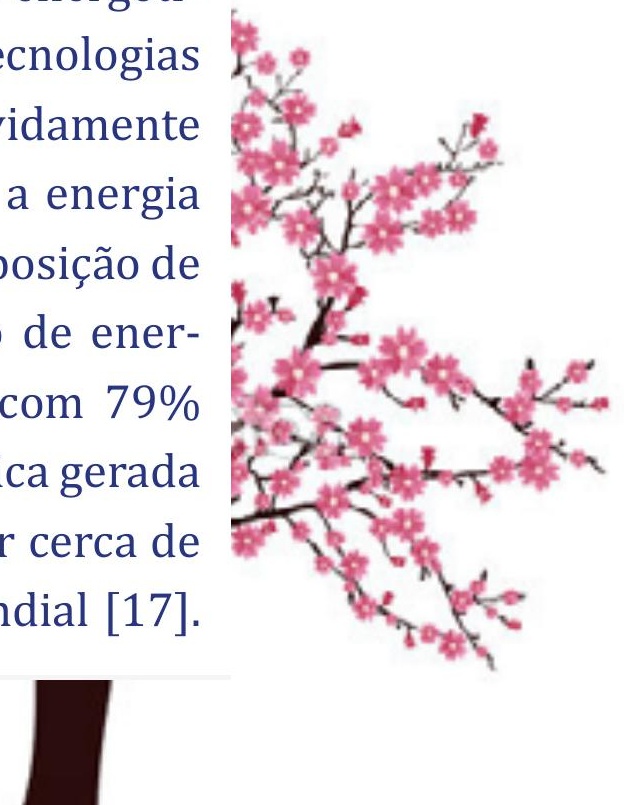
rível que as usinas conversoras situem-se próximas ao ambiente de geração da biomassa [21] "Para a produção industrial de energia, de 80 a 100\% do suprimento de biomassa deve vir de plantações, e o uso de biomassa em larga escala pode levar a competição com a agricultura para alimentação. Mas a produção de energia pela biomassa não deve chegar a esse ponto, pois até 2100 serão necessários 1,7 bilhão de hectares extras para sustentar um alto crescimento na produção de biomassa. Isso mostra que o uso de biomassa para geração de energia é sustentável nos próximos cem anos, sem conflitos com o uso de terras para agricultura de alimentos". Pesquisas mostram que no futuro haverá muitas vantagens em se produzir energia a par- tir da biomassa, quando as fontes de energia renováveis forem mais competitivas em relação aos combustíveis fosseis, o que é esperado até 2020. Aproximadamente 11\% da energia produzida mundialmente originam-se deste insumo [12].

\section{Energia Solar}

- Sistema Solar Térmico

Existem dois tipos princi29 pais de sistemas de energia solar térmica, os de circulação em termossifãoeosdecirculaçãoforçada. Circulação em termossifão: Nos sistemas termossolares, a energia solar é utilizada para produzir vapor que aciona uma turbina a vapor [13]. 0 aquecimento de água por esse processo é uma tecnologia viável e economicamente competitiva, e suas maiores aplicações verifi-

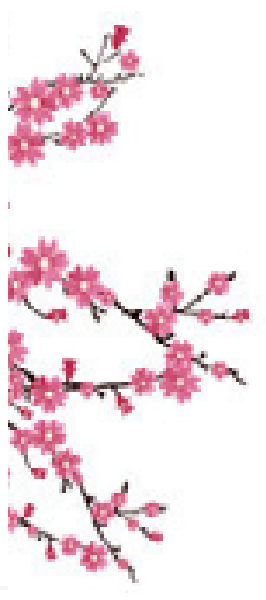




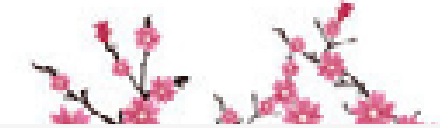

cam-se no uso domestico [15],

- por oferecer instalações e manutenções simples. Funciona de forma autônoma, sem recurso a bomba auxiliar para fazer a circulação do líquido solar [22]. Circulação forçada: A radiação solar incide sobre a cobertura de $:$

30

vidro que compõe a parte superior do coletor solar, penetrando no interior do painel solar. 0 calor é transferido para o fluido que circula pela tubulação. 0 fluido quente circula em circuito fechado e transfere calor através da serpentina do depósito para a água de consumo. A circulação do fluido é gerida pelo controlador diferencial e pelo grupo de circulação em função das temperaturas medidas. O sistema de circulação forçada tem um rendimento superior, dado que a gestão da energia é mais eficaz por ser regulada por meio de um controlador diferencial [23].

A energia solar não apresenta emissão de poluentes, não contribuindo para o efeito estufa, é isenta de ruídos sendo desta forma uma das alternativas mais indicadas dentro de um desenvolvimento sustentável.

- Sistema Solar Fotovoltaico

Nos sistemas fotovoltaicos a conversão de energia solar em energia elétrica é feita de forma direta [13] através de painéis fotovoltaicos baseados em materiais semicondutores [24]. Essa fonte não apresenta impactos ambientais diretos, mas a produção dos painéis solares causam impactos ambientais. 0 sistema não necessita de água para sua refrigeração, podendo ser utilizada em áreas urba-

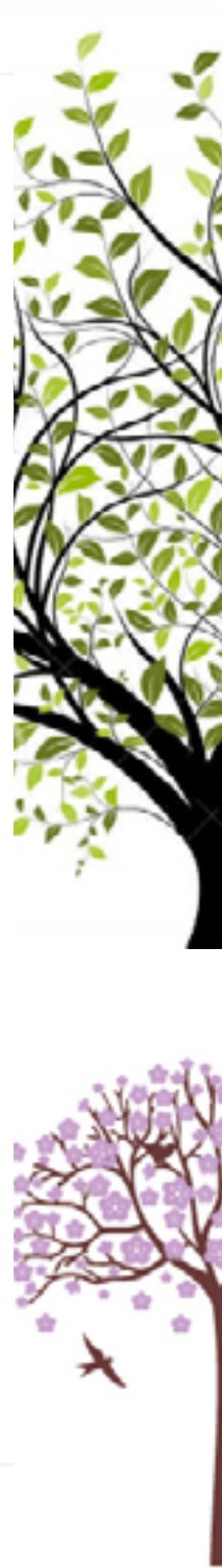


nas eletricamente congestionadas. Contudo, sua produção ainda é muito pequena já que está fora do alcance do consumidor médio devido ao alto custo de fabricação dos painéis [25].

\section{Energia Eólica}

Entre as fontes renováveis de energia a eólica é a mais promissora e desenvolvida e apresenta um grande potencial para geração de energia elétrica. Com o surgimento de novas tecnologias, sua utilização vem crescendo rapidamente $[13,25]$. Uma grande vantagem do uso de centrais eólicas é a quase total ausência de impactos ambientais, sendo que seus geradores não causam poluição ou gases que contribuem para o aumento do efeito estufa, sendo também uma boa alternativa para o desenvolvimento sustentável. Os possíveis impactos causados por essa fonte estão os ruídos produzidos pelos aerogeradores, colisão de pássaros, impacto visual e limitação do uso de espaço [13], pode interferir nos radares de vigilância e os melhores locais são distantes dos centros urbanos [25]. Existem atualmente 29 países com programas ativos de energia eólica sendo a Alemanha, os Estados Unidos, Espanha e Dinamarca seus maiores produtores [13].

\section{Energia Geotérmica}

A energia geotérmica é uma fonte de energia alternativa que é encontrada em locais especiais da superfície terrestre. Numa central de energia geotérmica, utiliza-se o calor existente nas camadas interio-

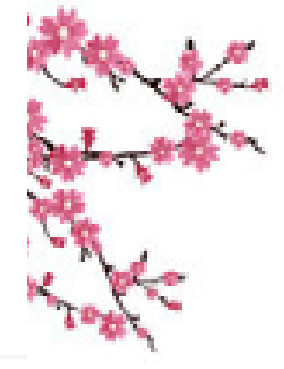

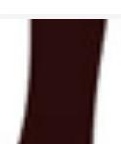




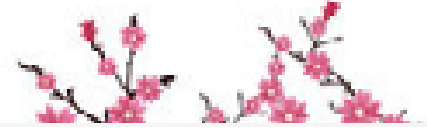

res da Terra, para produzir o

cúrio (Hg), arsênico (As), lixo - vapor que irá acionar a turbina sólido, água residual, pequenos [25], gerando eletricidade por tremores, rebaixamento de solo, a localização das fontes está submetida à natureza e nem sempre cipais: energia hidrotérmica, rocha quente e seca, reservatórios geopressurizados e magma [13]. 0 uso da energia gerada do mag* ma esta em estudo teórico [26]. Diferente das usinas solares ou eólicas, a usina geotérmipróxima de linhas de transmissão [25]. Contudo, todos esses impactos podem ser controlados, colocando a energia geotérmica dentro das fontes que pouco causa impactos ambientais. ca opera sob demanda, já que o calor da Terra está sempre disponível e geralmente as usinas funcionam ininterruptamente [25]. O uso da energia geotérmica, principalmente na forma de calor, emite menos gases que os combustíveis fósseis. Sua operação envolve alguns impactos, como ocupação do solo, efeito estético, ruídos, emissão de gases poluentes (H2S e CO2), elementos tóxicos como merOs EUA são os principais produtores de energia elétrica proveniente dessa fonte, produzindo 2850 MW [27].

Energia dos Oceanos

A energia dos oceanos pode ser utilizada na forma de marés (a mais avançada e com maiores plantas em operação), ondas, gradiente térmico, salinidade, correntes e biomassa marítima, sendo uma

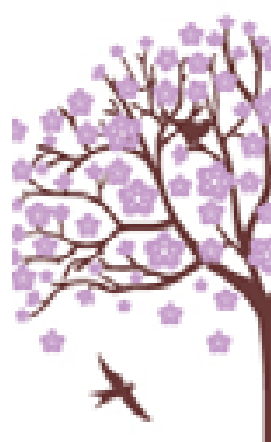


energia de baixa densidade. a água através de uma turbina. 0 aproveitamento desta fonte As tecnologias de alto mar em não causa emissão de poluentes produção também incluem cana atmosfera além da barragem nais afunilados e dispositivos de poder proteger a costa quando coluna de água oscilante (OWC) detempestadesmarítimas. Desta construídos em boias [28]. forma, é uma alternativa na produção de energia com agressões mínimas ao meio ambiente [13]. As tecnologias de onda presas como as ancoradas ao solo oceânico estão a ser preparadas para ser aplicadas em alto mar, onde a profundidades da água é de mais de 40 metros. Muitos destes protótipos exploram o movimento diferencial de bóias As estruturas podem afetar negativamente o aspecto estético do local onde for implementado [13], além do fato da construção de estruturas duráveis em locais com arrebentação forte ser cara [25]. A energia oceânica, apesar de ter excelente potencial de utilização, se apresenta deforma difusa dificultando sua utilização econômica. Este tipo de geração de energia já está passando por testes, mas ainda não está disponível para comercialização [25], sendo Portugal o país pioneiro com duas centrais de aproveitamento [15]. outros empregam bóias que se movem em direção ao solo oceânico. Nestas tecnologias, os movimentos ascendentes e descendentes são usados para mover bombas hidráulicas ou forçar
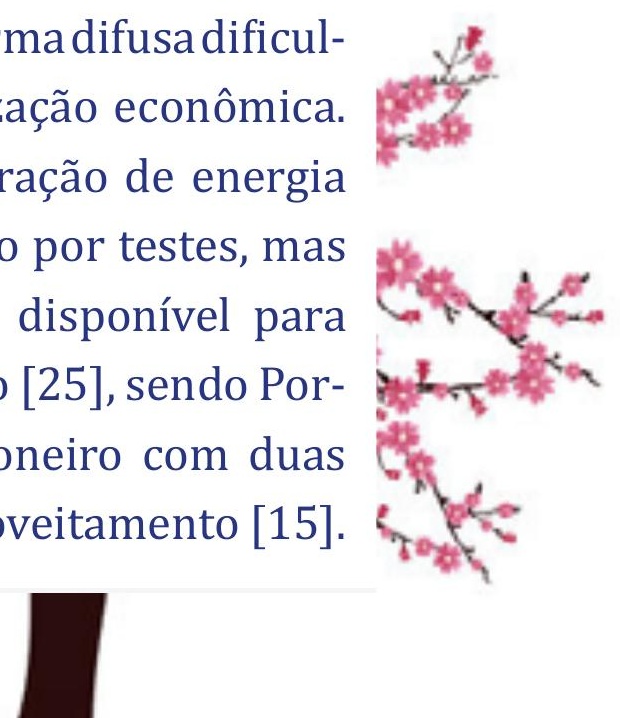
ceiro lugar na matriz energética mundial e aproximadamente $13 \%$ das termelétricas mundiais são abastecidas por ele sendo estas responsáveis por 3\% da produção de energia primária no mundo [13]. Sendo assim, o gás é uma fonte de energia de potencial para o século XXI por tratar-se de um tipo de combustível limpo e a busca pelo desenvolvimento sustentável deve aumentar o esforço para localizar novas reservas deste insumo [12].

\section{Energia Nuclear}

A energia nuclear é produzida por meio das reações de fissão ou fusão dos átomos, durante as quais são liberadas quantidades de energia que podem ser utilizadas para produzir energia elétrica. A fissão nucle- ar utiliza minerais presentes na natureza, como urânio e tório, como combustível e consiste na fissão de um núcleo pesado em dois núcleos de massa menores e dois a três nêutrons, que irão fissionar outros tantos núcleos de urânio-235, sucessivamente liberando muito calor. 0 processo de fusão nuclear consiste na união de dois núcleos leves para formar outro mais pesado 35 e com menor conteúdo energético, por meio do qual se libera energia em grandes quantidades. Este processo envolve átomos leves, como os de deutério, trítio ou hidrogênio [15]. 0 processo de fusão tem se mostrado de difícil controle. Já o processo de fissão é mais fácil de ser controlado e também são liberadas quantidades de energia, o que levou ao crescimento do seu

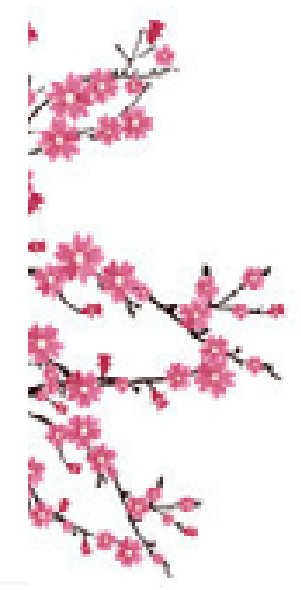

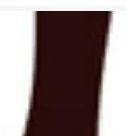




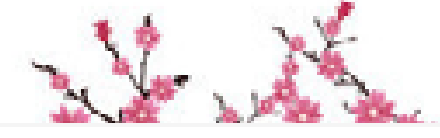

- para o uso como combustível devido à liberação de quantidade de energia no processo de fissão [29]. A fissão de urânio produz quantidade de energia quando comparado com outros combustíveis fosseis. $1 \mathrm{~kg}$ de urânio produz 14.000 vezes mais energia que $1 \mathrm{~kg}$ de petróleo [12]. Com relação à emissão de gases efeito estufa, na produção de $1 \mathrm{kWh}$ de energia elétrica, uma usina carvão emite 995 gramas de CO2 , a óleo 818 gramas, a gás 446 gramas e a nuclear apenas 4 gramas [30]. As principais tecnologias de reatores nucleares são os reatores a água leve $(75 \%$ das usinas utilizam esse tipo de reator), reatores a água pesada (8\% de utilização), reatores a gás (está em desuso) e reatores refrige- rados a metal liquido/reatores super regenerados rápidos [13]. Ao contrário de outras fontes, o custo principal da energia nuclear deriva da construção das usinas, e não do combustível, visto que o urânio é relativamente barato. Além disso, a energia nuclear é limpa e sustentável, já que não produz gases de efeito estufa, não necessita de grande área e produz baixos impactos ambientais [16]. É importante citar também que o uso da radiação gerada por meio da fusão pode ser aplicada em diversas áreas: industria, agricultura e meio ambiente e também na medicina, onde se aplica em técnicas avançadas de diagnóstico e no tratamento de câncer [29]. As reservas de urânio, que são avaliadas em 2,3 milhões de to-

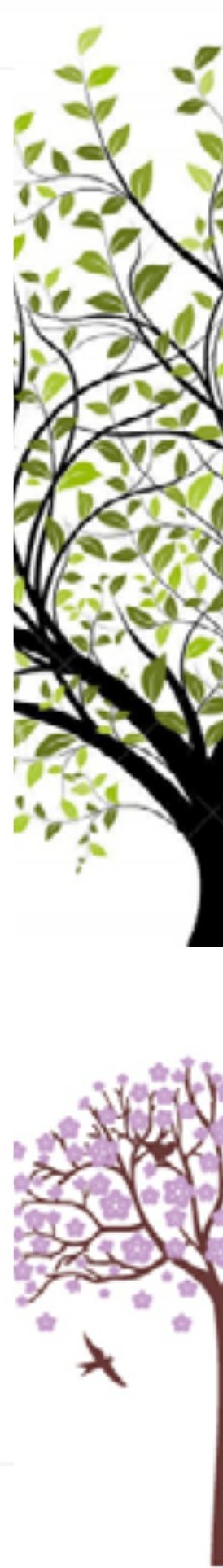


neladas, são suficientes para abastecer todos os reatores em funcionamento por pelo menos mais um século [36]. As maiores reservas desse mineral encontram-se em países pacíficos como a Austrália, Canadá e Brasil (a reserva brasileira é a sexta do mundo). Em função disto, seu suprimento dificilmente será ameaçado por grandes crises como as que ocorrem nos países produtores de petróleo [12, 16]. Os riscos referentes ao transporte são mínimos se respeitados os procedimentos e recomendações das normas de segurança, não há registro no mundo de fatalidades decorrentes de acidentes envolvendo o transporte de material radioativo ou nuclear [20]. 0 que dificulta a disseminação da tecnologia nuclear na geração de energia é a formação do subproduto do processo, ou seja, o lixo atômico. Alguns desses rejeitos radioativos duram dezenas de milhares de anos, período em que devem ser mantidos em cápsulas seguras de concreto e chumbo [16]. É importante salientar que o combustível usado durante todo o período de vida útil de até 20 reatores iguais ao de Angra II pode ser armazenado em uma área do tamanho de um campo de futebol, isto quer dizer que o problema é facilmente gerenciável [29]. Hoje no Japão, é investigado por cientistas que trabalham no projeto $\mathrm{Ku}$ matori, a possibilidade de construir um reator subcrítico que com a ajuda de um acelerador de partículas é capaz de diminuir o tempo de vida da radioatividade de resíduos de milhares para centenas de anos, o reator

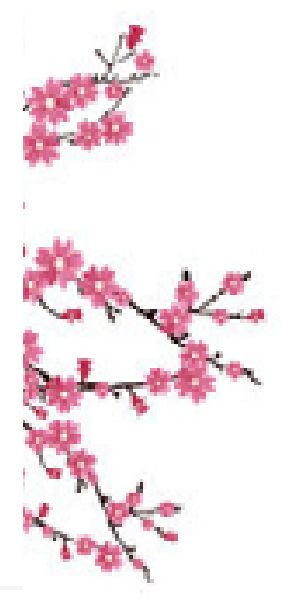




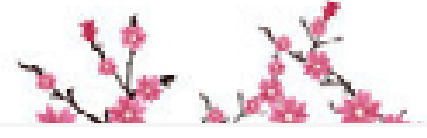

deve começar a operar em 2015. Environmentalists for Nuclear

\ 0 auge da energia nuclear como alternativa na geração de energia veio em maio de 2007, com o relatório do Painel Intergovernamental de Mudanças Climáticas (IPCC), órgão da ONU criado para ser autoridade mundial em

aquecimento global, e este órgão afirmou que a energia nuclear é fundamental para o planeta deixar de aquecer. De acordo com os dados do relatório é necessário que os países concentrem-se em sistemas energéticos que não emitem carbono como os sistemas renováveis e nucleares [16]. Patrick Moore, um dos fundadores do Greenpeace, assegura que a energia atômica é a "única maneira de evitar uma catástrofe climática". Os defensores dessa nova vertente vêm se organizando, por meio da organização
Energy (Ambientalistas a favor da Energia Nuclear), presente em 17 países - como Canadá, França, Estados Unidos e China [31]. Aproximadamente $16 \%$ da energia elétrica mundial é gerada a partir de centrais nucleares. Os principais produtores são os EUA, alguns países que fizeram parte da URSS e os países europeus. No Brasil, a energia nuclear ainda é pouco utiliza$\mathrm{da}$, correspondendo a 1,3\% do total gerada [13]. Atualmente estão em operação 440 reatores nucleares para geração de energia em 31 países e outros 33 estão em construção, além de 284 reatores de pesquisas operando em 56 países e em torno de 220 reatores de propulsão em navios e submarinos [29]. A Agência Internacional de

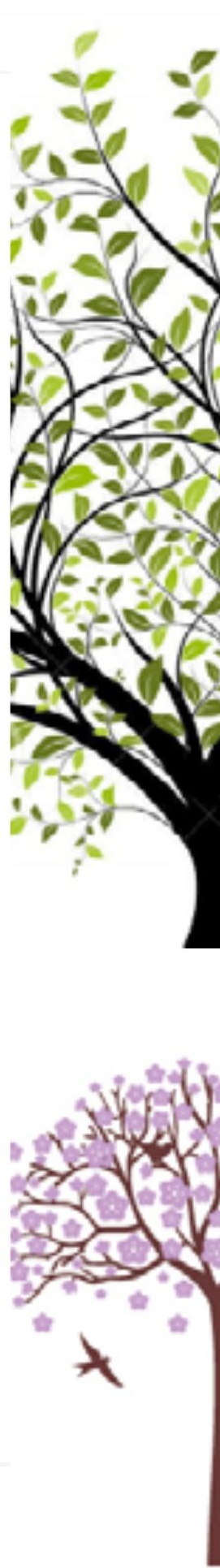


Energia prevê um crescimento na geração de energia nuclear entre 13 a 40\% até 2030. 0 Brasil, por ter tecnologia e autorização para enriquecer urânio está inserido neste potencial [16].

\section{Sustentabilidade e}

Desenvolvimento

\section{Energético}

O setor básico de energia afeta todos os demais, o acesso à energia influencia fortemente o desenvolvimento humano, já que, existe uma forte relação entre energia e desenvolvimento. No centro de qualquer estratégia visando o desenvolvimento sustentável está um meio de viabilizar a produção e o uso da energia de forma a contribuir para a sustentabilidade e para isso são necessárias mudanças. Um exemplo é o racio- namento brasileiro de 2001, quando a sociedade despertou para a economia de energia e deu um passo importante em direção a um dos princípios para o desenvolvimento sustentável: a moderação no consumo. A eficiência energética e o uso racional são pré-requisitos no modelo de desenvolvimento sustentável e as políticas que visam o uso sustentável da energia devem encorajar o aumento do uso de fontes renováveis, criando dispositivos que favoreçam o seu uso, aumentado os mercados e criando novas tecnologias que aumentem a eficiência do uso da energia e diminuam seus impactos ambientais. Já existe um novo consenso global sobre a necessidade da criação de um novo paradigma energético aliado ao objetivo de atin-
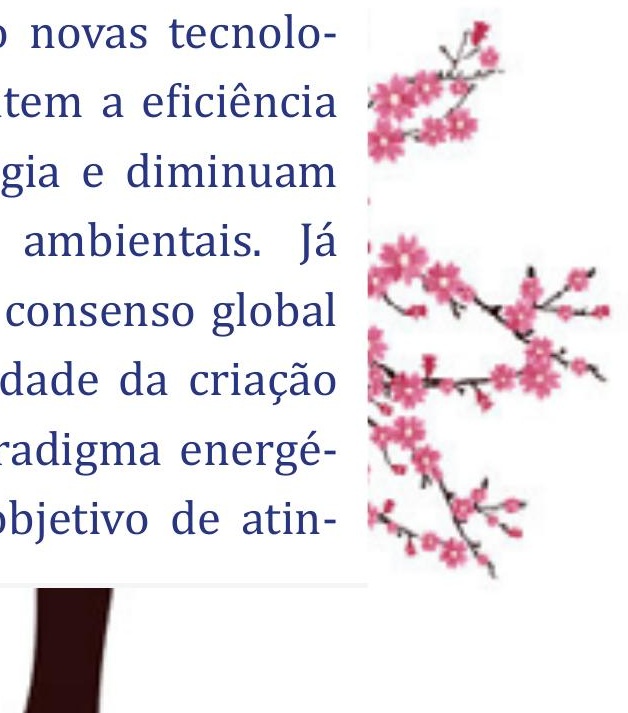


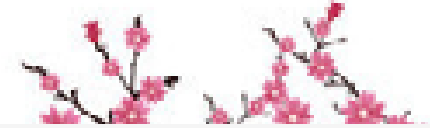

- gir essa sustentabilidade [7]

No atual paradigma, os méto-

conservação de energia, a efici-

* dos de previsão de demanda ência energética e o uso racional minimizam a necessidade de gebaseiam-se principalmente em analises do consumo do passado e projeções da economia. A potencialidade de mudanças nos padrões de consumo, ganhos de $\geqslant$ eficiência, mudanças na matriz energética e disseminação de novas tecnologias para a produção de energia praticamente são ignorados, estando focado na produção de mais energia quando há desequilíbrio entre oferta e demanda, buscando soluções para o desequilíbrio dentro do próprio setor. Para que os sistemas energéticos estejam focados na promoção do bem estar das populações e sejam inseridos em um modelo de desenvolvimento sustentável é necessário que haja quebra de paradigma. A ração. Além disso, é fundamental a regulamentação bem definida do setor. Esse novo paradigma depende, além do comportamento dos sistemas energéticos, do comportamento das pessoas que esta ligado a sua cultura. Os obstáculos ao uso eficiente de energia variam por diversas razões, incluindo treinamento técnico e educação, imperfeições no mercado, tradições residenciais, questões financeiras, legislação vigente na região além da dificuldade de quantificar e demonstrar seus impactos. A utilização de combustíveis fósseis e as queimadas são as principais causas do aumento da temperatura global causada pelos gases de efeito estufa, o que nos

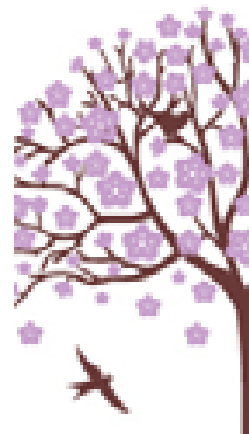


leva a pensar em outras fontes renováveis e alternativas limpas. 0 uso de energia deve deixar de ser considerada primeiramente como uma questão setorial para ser vista sistemicamente junto com questões sociais e ambientais [8] que ainda são grandemente subestimadas dificultando a formulação de políticas energéticas sustentáveis [13]. A decisão de adicionar combustível bioenergético (álcool) à gasolina para abastecimento de veículos automotores mostra a possibilidade de adequação dos energéticos da região às condi-

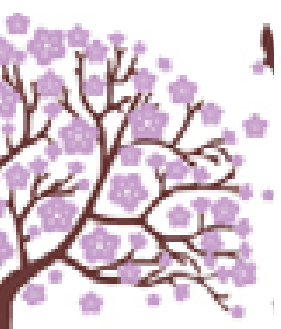

ções de sustentabilidade, visando garantir o não comprometimento das gerações futuras [7]. O impacto do efeito estufa no clima caminha rapidamente para tornar-se o maior desastre ambiental da historia da civilização.
0 que temos pela frente é uma corrida contra o tempo no esforço de conter a deterioração ambiental. A utilização de energias alternativas começa a se tornar realidade, mudando os conceitos energéticos do planeta, explorando fontes renováveis e retomando a energia nuclear [32]. Os recursos de energia disponíveis são suficientes para construir um desenvolvimento sustentável. Existem muitos recursos alternativos, porém os custos de produção são altos comparados com os utilizados atualmente. Os recursos renováveis são abundantes, mas grande parte ainda não dispõe de tecnologia para seu aproveitamento e algumas que dispõem de tecnologia ainda não são comercialmente aproveitáveis. Alternativas não faltam

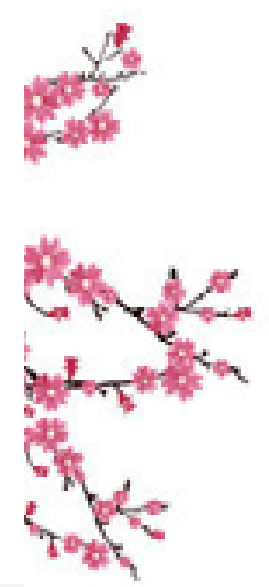




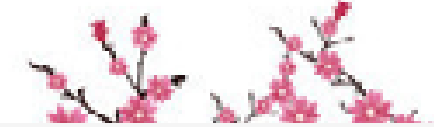

para um futuro sustentável de

- abastecimento de energia onde fontes de energia mais lim-

s.t. pas podem ser utilizadas [13].

42
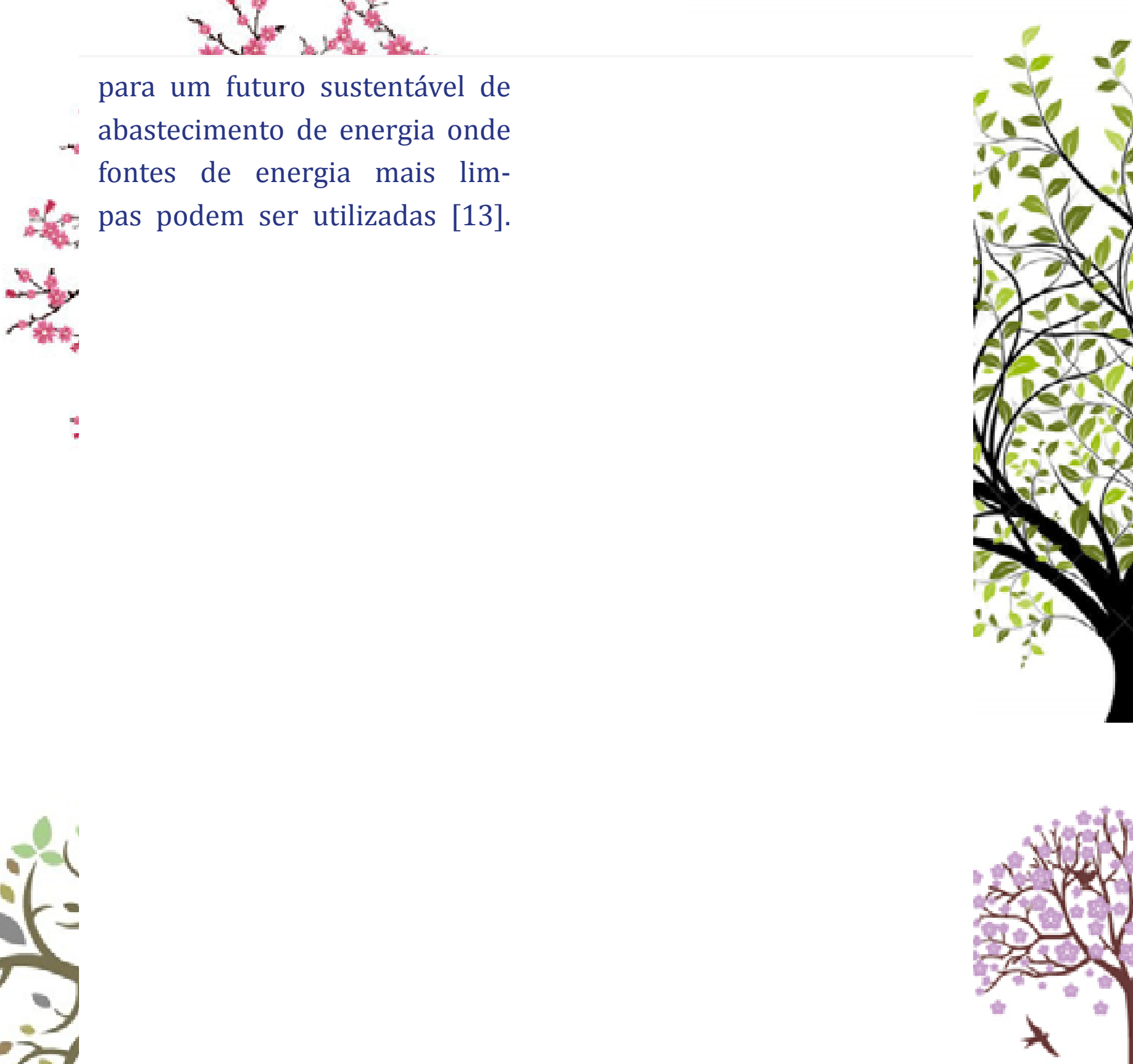


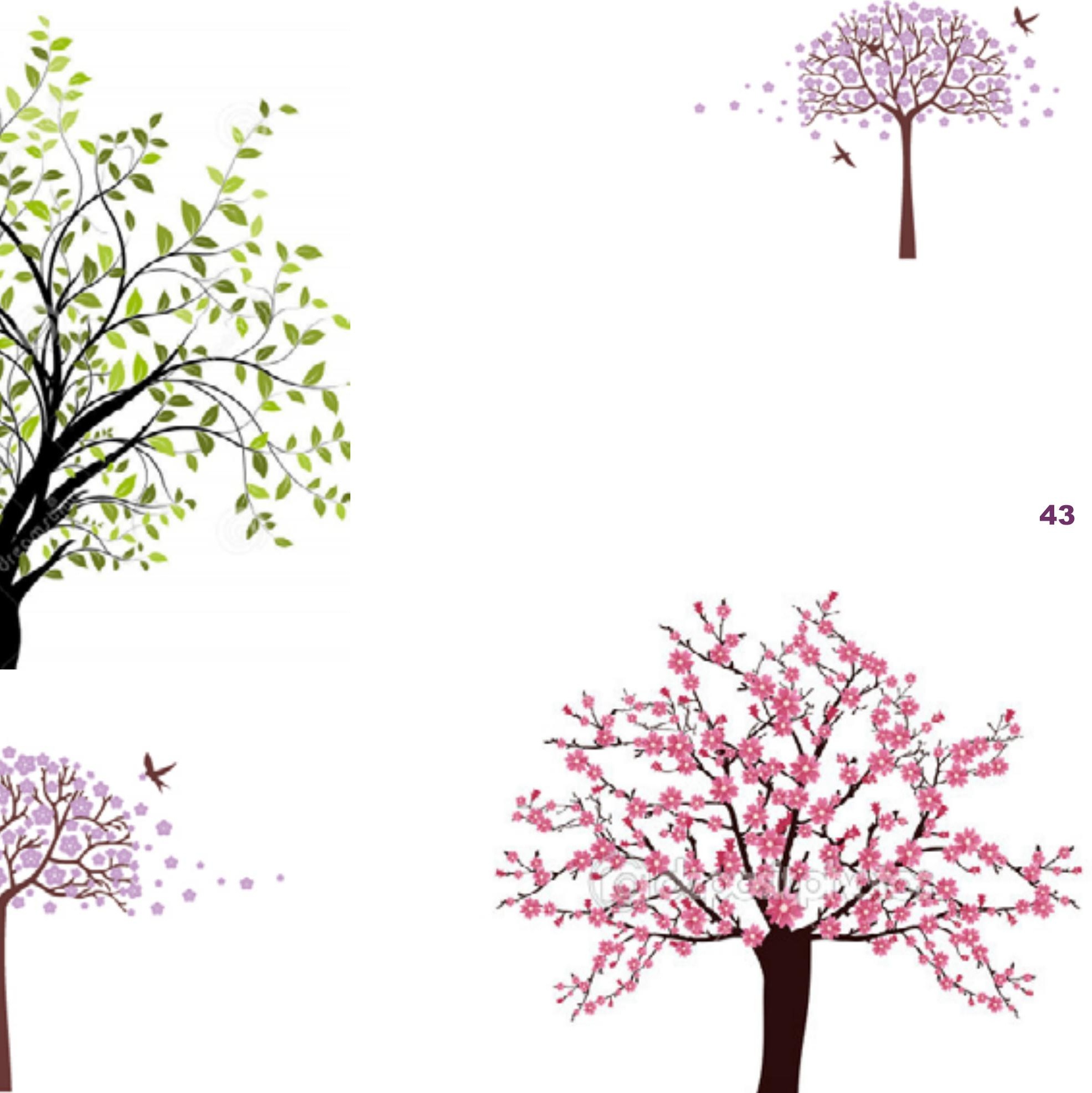


empresas utilizam estratégias para conquistar o consumidor e vencer a batalha da competitividade global. A embalagem, dentre outras funções, surge como uma ferramenta estratégica para divulgação da marca e do produto, sendo um dos fatores que podem contribuir para a decisão da compra. 0 grande problema está no descarte destas embalagens, pois segundo dados do IBGE e Ministérios das Cidades, mais de $25 \%$ do lixo produzido nas cidades poderiam ser recicláveis ou reaproveitados. E quem fica com o prejuízo é o meio ambiente e as futuras gerações. Diante deste contexto a reutilização, a reciclagem, reuso e a logística reversa surgem como alternativas que evidenciam as preocupações com as dimensões econômicas, sociais e ambientais apontadas [35]. Analisando as publicações recentes sobre o tema, percebe-se que existe um consenso por determinados indicadores. A construção de indicadores de desenvolvimento sustentável no Brasil integra-se ao conjunto de esforços internacionais para concretização das ideias e princípios formulados na Conferência das Nações Unidas sobre Meio Ambiente e Desenvolvimento, realizada no Rio de Janeiro em 1992, no que diz respeito à relação entre meio ambiente, desenvolvimento e informações para a tomada de decisões. Com a publicação, Indicadores de Desenvolvimento Sustentável: Brasil 2008, o IBGE dá continuidade à série iniciada em 2002, mais uma vez colocando à disposição da socieda-
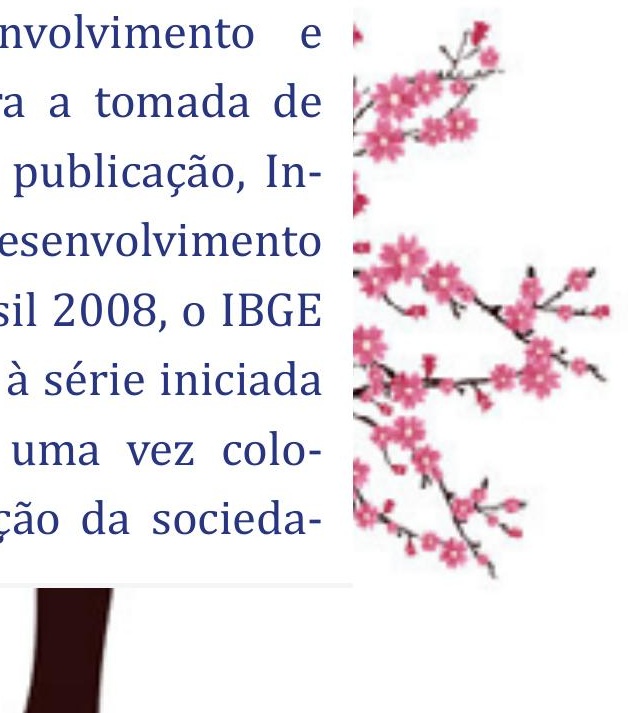


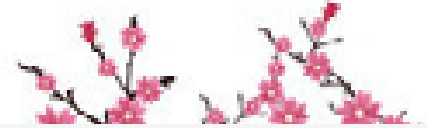

de um conjunto de informações sobre a realidade brasileira, em suas dimensões ambiental, social, econômica e institucional. A conquista do desenvolvimento social é uma aspiração de abrangência universal, toma feições concretas em cada país, nasce de suas peculiaridades e responde aos problemas e oportunidades de cada nação. Portanto a escolha dos indicadores de desenvolvimento sustentável reflete as situações e especificidades de cada país, apontando para a necessidade de produção regular de estatísticas sobre os termos abordados. Estabelecendo comparações entre países e regiões, indicando necessidades e prioridades para a formulação, monitoramento e avaliação de políticas ambientais [36].

\section{Dimensão Ambiental}

A construção de indicadores de desenvolvimento sustentável no Brasil integra-se ao conjunto de esforços internacionais para concretização das ideias e princípios formulados na Conferência das Nações Unidas sobre Meio Ambiente e Desenvolvimento, realizada no Rio de Janeiro em 1992, no que diz respeito à relação entre meio ambiente, desenvolvimento e informações para a tomada de decisões.

$\mathrm{Na}$ publicação Indicadora de Desenvolvimento Sustentável: Brasil 2010, o IBGE dá continuidade à série iniciada em 2002, reafirmando, mais uma vez, seu compromisso de disponibilizar à sociedade um conjunto de informações sobre a realidade brasileira, em suas dimensões ambiental, social,

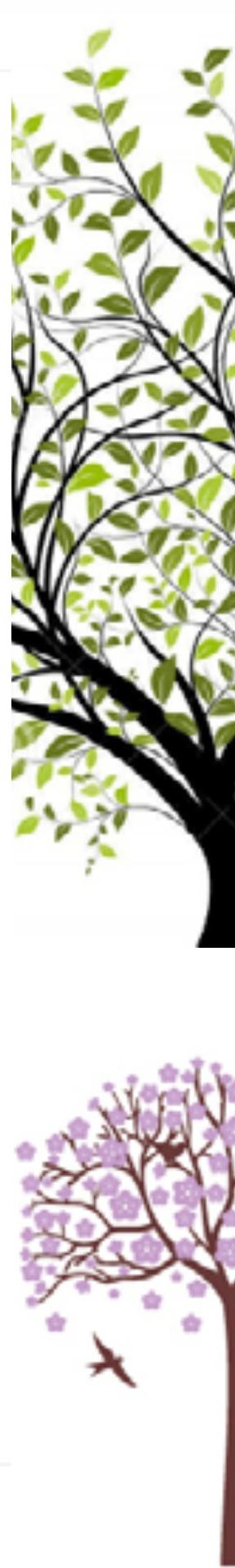


econômica e institucional [37]. te. É preciso haver cidadãos e Uso dos recursos naturais e a líderes alfabetizados no aspecto degradação ambiental esta relacionada aos objetivos de preservação e conservação do meio ambiente, fundamental ao beneficio das gerações futuras. Portanto, produção limpa é a no que tange ao gasto social e continua aplicação de uma estratégia ambiental preventiva e integrada, aplicada a processos, produtos e serviços para aumentar a eco-eficiência e reduzir riscos humanos e ao ambiente.

\section{Dimensão Social}

Objetivo ligado à sustentação das necessidades humanas, melhoria da qualidade de vida e justiça social, buscando retratar a situação social, a distribuição de renda e as condições de vida da população, apontando o sentido de sua evolução recenambiental para construir sociedades mais sustentáveis e justas. É necessário ainda tratar as áreas mais frágeis numa perspectiva sub-regional diferenciada às políticas de emprego e renda. A intenção é estimular uma convergência das prioridades de gasto da União, estados e municípios, num conjunto de políticas estruturantes (transferência de renda, saneamento, habitação, saúde, educação, informação e conhecimento, meio ambiente, associadas toda a uma política sob medida de emprego e renda), gerenciadas de forma articulada, visando ao desenvolvimento local [38].

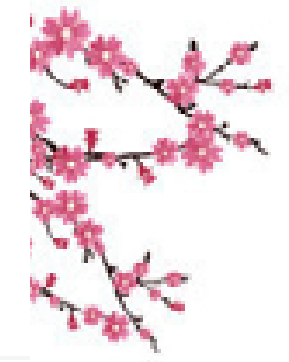




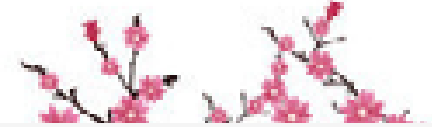

Dimensão Econômica

Trata do desempenho macro econômico e financeiro e dos impactos no consumo de recursos materiais e o uso de energia primaria. Ocupa-se com os objetivos de eficiência dos processos produtivos e com as alterações nas estruturas de consumo orientados e uma produção econômica sustentável ao longo prazo.

O desenvolvimento econômico é inevitável e necessário. Contudo, para a própria empresa garantir lucro a médio e longo prazo é preciso combinar a dimensão econômica com as questões sociais e ambientais pertinentes à própria sobrevivência da empresa e de sua responsabilidade com a comunidade e a preservação do meio ambiente.

A sustentabilidade econômica de uma empresa, fundada na valorização da livre iniciativa e do trabalho a fim de assegurar aos empresários, trabalhadores e clientes condições econômicas para viver com dignidade, será duradora com prática, ética das estratégias de negócios, da vantagem competitiva, do investimento, do lucro, dos resultados, da relação com os acionistas, clientes e fornecedores [39].

\section{Dimensão Institucional}

Orientação política, capacidade e esforço desprendido para as mudanças requeridas para uma efetiva implementação do desenvolvimento sustentável. Aborda temas de difícil medição e carece de mais estudos para o seu aprimoramento [40]. Entre esses temas estão a função de Proteção o Meio Ambiente, inclui a administração,

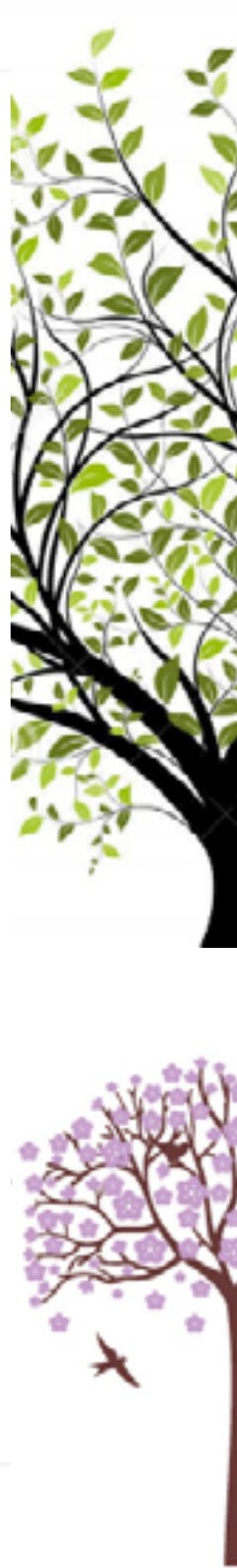


tano é o segundo gás de efeito estufa mais importante, depois do dióxido de carbono. Entretanto, o metano tem uma meia-vida na atmosfera de aproximadamente dez anos, enquanto $\mathrm{CO} 2$ tem uma meia vida mais longa. Isso pode a princípio parecer menos nocivo, mais existem efeitos indiretos a considerar. Na troposfera o metano é atacado por espécies reativas como os radicais de $\mathrm{OH}-$, ou óxidos de nitrogênio, eventualmente produzindo outros gases de efeito estufa como 03 . Tem sido estimado que os efeitos de $\mathrm{CH} 4$ na mudança no clima são no mínimo um terço, ou talvez até mesmo metade, tão grandes quanto os de CO2. Dada essa grande contribuição, reduções importantes do efeito estufa poderiam ser atingidas pela redução das emissões de metano ou capturando-se as emissões para uso como um combustível [43]. O CO2 é um gás incolor, subproduto da combustão de matéria orgânica. Ele representa menos de 0,04\% da atmosfera da Terra, a maior parte foi liberada muito cedo na vida do planeta pela atividade vulcânica. Atualmente, a atividade humana lança enormes quantidades de $\mathrm{CO} 2$ na atmosfera, resultando em aumen-

to total da sua concentração. O aumento da concentração é considerado o fator primário no aquecimento global, porque o C02 absorve radiação infravermelha. Como a maior parte da energia que escapa da atmosfera da Terra sai na forma de radiação infravermelha, o CO2 extra, significa maior absorção de energia e um aumento total na temperatura do planeta [27].

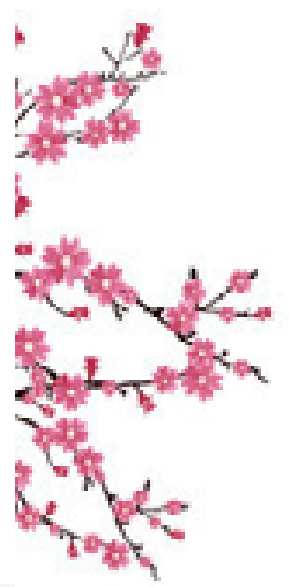

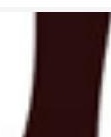




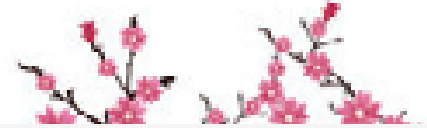

Os cientistas climáticos são unâ-

aumentam o efeito estufa no nimes em afirmar que o impacto planeta. 0 principal objetivo do aquecimento será enorme. A é que ocorra a diminuição da A. maioria prevê falta de água potável, mudanças drásticas nas condições de produção de alimentos e aumento no número de mortes causadas por inundações, secas, : tempestades, ondas de calor e fenômenos naturais como tufões e furacões. Além disso, pesquisadores europeus e americanos estimam que, caso as calotas polares derretam, haverá uma elevação de cerca de 7 metros no nível dos oceanos. Outro impacto provável é a extinção de diversas espécies animais e vegetais [21]. 0 Protocolo de Kyoto tem sido acompanhado ao longo desses anos com críticas e ressalvas. Este protocolo é um acordo internacional que visa a redução da emissão dos poluentes que temperatura global nos próximos anos. Infelizmente os Estados Unidos, país que mais emite poluentes no mundo, não aceitou o acordo, pois afirmou que ele prejudicaria o desenvolvimento industrial do país. 0 alerta dos cientistas sobre o aquecimento global e suas consequências, que há poucos anos mobilizava apenas órgãos técnicos de governos e ambientalistas, hoje se tornou um tema onipresente. 0 combate ao aumento do efeito estufa está na retórica dos políticos e nos planos de negócios dos empresários. Virou ferramenta de marketing na publicidade e de autopromoção entre celebridades. É fator preocupante a possibilidade de ocorrerem

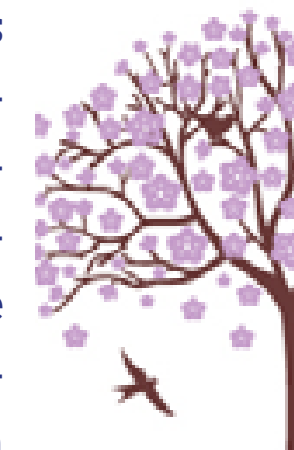


catástrofes cada vez mais devastadoras por causa da elevação da temperatura no planeta [45].

\section{Protocolo de Kyoto}

A ratificação do Protocolo de Kyoto abriu perspectivas para que recursos externos sejam direcionados a projetos no Brasil que atinjam o desenvolvimento sustentável e contribuam para reduzir o efeito estufa por meio do Mecanismo de Desenvolvimento Limpo (MDL). Projetos com reduções certificadas de emissões de gases de efeito estufa (GEE) poderão gerar créditos de carbono, negociáveis com os países desenvolvidos. Mas, conforme o Artigo 12 do Protocolo de Kyoto, esses projetos têm que atingir a sustentabilidade, o que significa atender a critérios econômicos, ambientais e sociais.
Certamente o critério social tem sido pouco explorado [27]. Com o aumento das discussões sobre o desenvolvimento sustentável, cada vez mais estão sendo geradas metodologias que objetivam determinar a sustentabilidade de uma determinada região.

\section{Conferência de Bali}

A Conferência de Bali realizada entre os dias 3 e 14 de dezembro de 2007, na ilha de Bali (Indonésia), a Conferência da ONU sobre Mudança Climática terminou com um avanço positivo. Após 11 dias de debates e negociações, os Estados Unidos concordaram com a posição defendida pelos países mais pobres. Foi estabelecido um cronograma de negociações e acordos para troca de informações sobre as mudanças climá-

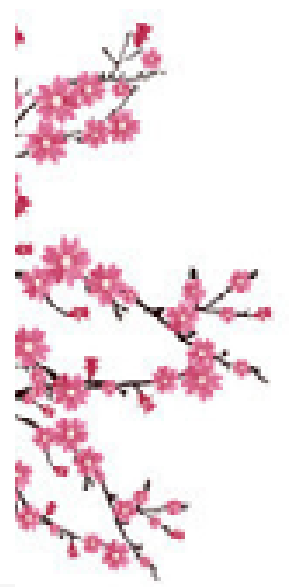

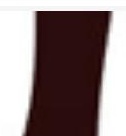




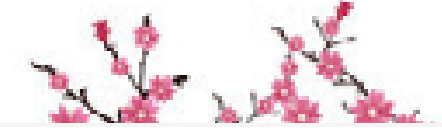

ticas, entre os 190 países participantes. As bases definidas substituirão o Protocolo de Kyoto, que venceu em 2012 [45; 46]. Gases de Efeito Estufa

Quanto uma empresa emi-

: te gases de efeito estufa, ela deve rastrear as emissões de carbono direta e indireta das suas Estufa ou do "GHG Protocol" ou ainda outra similar, até que a CETESB defina outra metodologia para o referido cálculo [47]. Os efeitos da poluição do ar atividades. Mais do que isso, construir um inventário de carbono, uma poderosa ferramenta de planejamento e controle. A metodologia para o cálculo das emissões estimadas poderá ser a da norma ABNT NBR ISO 14.064 -1 - Gases de Efeito

\section{Redução de Emissões de}

se caracterizam tanto pela alteração de condições consideradas normais como pelo aumento de problemas já existentes. Os efeitos podem ocorrer a nível local, regional e global.

certificada de emissões (RCE) são certificados emitidos quando ocorre a redução de gases do efeito estufa (GEE). Para alguns países desenvolvidos, reduzir a emissão de gases do efeito es-

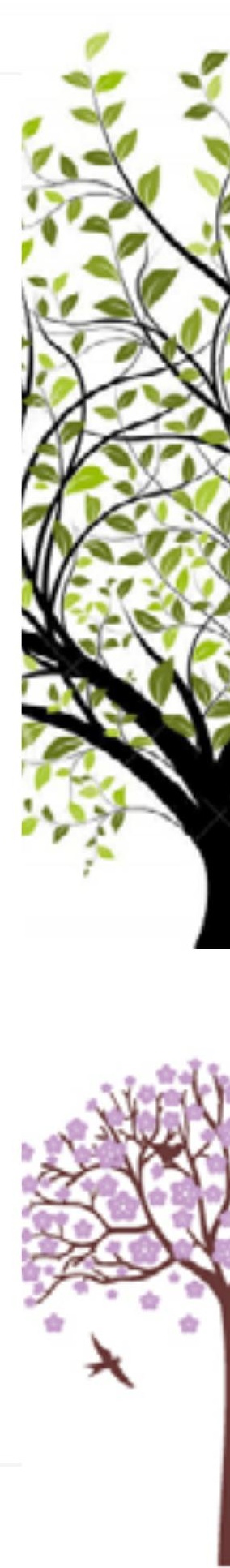


tufa pode significar alterações profundas colocando em risco suas economias. E justamente para evitar essa possibilidade de causar efeitos na economia dos países desenvolvidos que foi criado o Protocolo de Kyoto um sistema chamado de Mecanismo de Desenvolvimento Limpo (MDL), inserido neste os créditos de carbono [48]. Podemos citar como exemplo o Aterro Bandeirantes em São Paulo, considerado um dos maiores depósitos de lixo do mundo, recebendo cerca de 7 mil toneladas de lixo gerado pela cidade de São Paulo, isto é a metade do que a cidade produz. Neste local os gases produzidos, originários da decomposição de matéria orgânica eram queimados em drenos verticais e lançados na atmosfera. Para evitar a queima sem controle e o lançamento de toneladas de poluentes para a atmosfera e contribuindo para a redução da emissão de gases do efeito estufa (GEE) foi desenvolvido o projeto de construção de uma Central Térmica a Gás do Aterro Sanitário Municipal Bandeirante. 0 projeto consistiu na implantação de uma unidade de produção de energia limpa, a partir do aproveitamento adequado do gás metano gerado pelo lixo. A técnica consiste em converter o metano gerado pelo lixo, em gás carbônico (CO2), com a queima controlada do metano ( $\mathrm{CH} 4$ ) e aproveitando para gerar energia. Embora haja emissão de C02, o ganho é explicado porque o metano tem um poder de poluição 21 vezes maior que o gás carbônico. Significando que a conversão de uma substância em

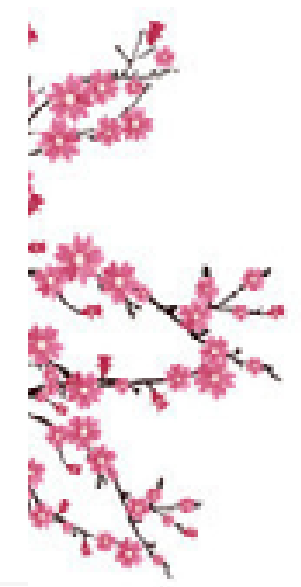




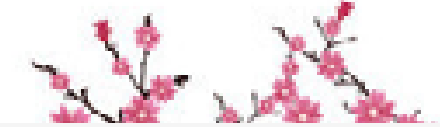

outra gera créditos de carbono. Portanto, cada crédito equivale a uma tonelada do gás, o valor de mercado varia de acordo com a cotação internacional, passa a ser um certificado para venda similar ao mercado de ações [49]. A abordagem ao proble-

* ma das mudanças climáticas não deve ser vista de forma isolada ou oportunista.

Reduzir as emissões continuamente, ano após ano, é o que garantirá futuro às empresas e aos seus mercados. A formulação de Orçamentos de Carbono, como projeções dos Inventários de Carbono, é uma das ferramentas usada na elaboração de projetos visando à compensação de carbono. Por exemplo: substituição de combustíveis fósseis por renováveis na geração de vapor, gases quentes, e outras aplicações industriais, utilizando resíduos, biocombustíveis e outras fontes renováveis; aterros sanitários urbanos: captação e aproveitamento energético do biogás; biodigestão de biomassa, resíduos e efluentes: produção e aproveitamento de biogás na agricultura, pecuária, frigoríficos, agroindústria em geral; processos industriais: siderurgia, alumínio, cimento, papel e celulose, indústria química; eficiência energética: redução de consumo de energia elétrica ou térmica; atividades florestais: energéticas ou para fins de suprimento de matérias primas.

\section{Água - Abastecimento e}

\section{Escassez}

0 aquecimento global afeta o ciclo da água, aumentando a evaporação, alterando as con-

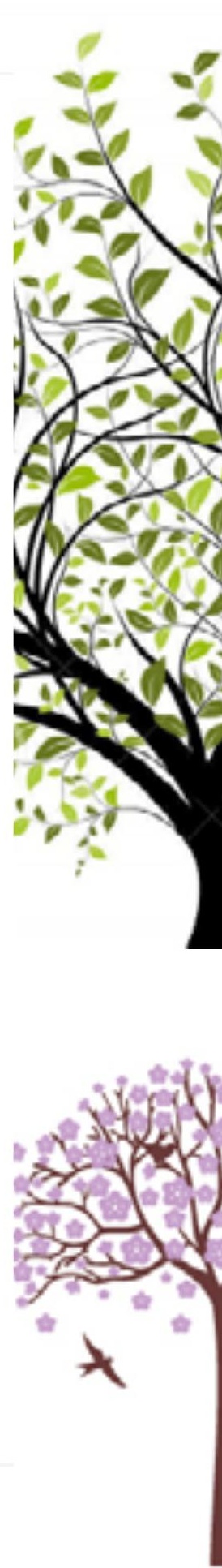


diçòes de chuvas, mudando a umidade do solo e o escoamento das águas sobre ele. Com isto, trará consequências sobre a quantidade de água disponível para consumo humano, tanto superficial quanto subterrânea.

Projeções para o final da primeira metade do século XXI indicam uma redução na quantidade da água de rios e na disponibilidade dessa água nas regiões mais secas e países tropicais, a exemplo do Nordeste brasileiro.

0 aumento da temperatura da água e a maior ocorrência de enchentes e de secas afetarão a qualidade da água e aumentarão a poluição provocada por diversos compostos, inclusive microrganismos, aumentando o risco à saúde humana [50].

0 aumento do nível dos mares contaminará por sal as águas subterrâneas próximas ao litoral, comprometendo seu uso. As mudanças climáticas afetarão o funcionamento dos sistemas de abastecimento de água e alguns destes poderão não ser capazes de resistir aos impactos de enchentes e da seca, agravados pelo crescimento populacional em algumas cidades. Haverá mais dificuldade para os serviços de abastecimento de água para planejarem o futuro das características dos seus mananciais de abastecimento, pois uma particularidade das mudanças climáticas é certa imprevisibilidade dessas variações [51]. Vivemos no planeta água na sua maioria água salgada que cobre cerca de $70 \%$ da superfície terrestre. Todos os organismos vivos são compostos por uma
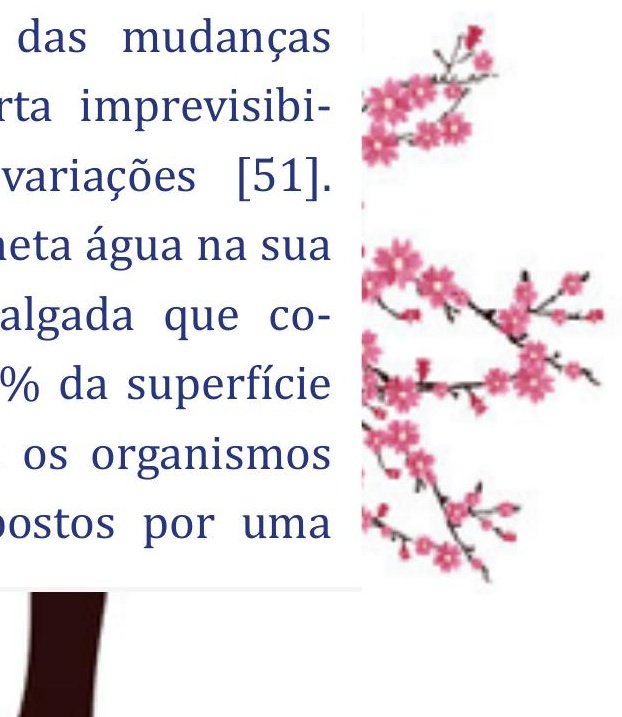


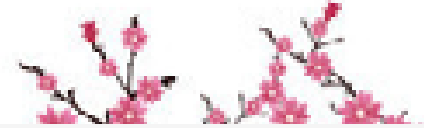

grande parte de água. Apesar de - sua importância, é um de nossos recursos mal administrado. Nós a desperdiçamos e poluímos. Somente pequena fração das abundantes reservas de água do planeta esta disponível como água doce. Se a reserva de água : do mundo tivesse apenas cem litros, nossa reserva utilizável de água doce seria apenas 0,014 litros ou 2,5 colheres de chá. 0 consumo de água vem aumentando rapidamente, e hoje milhões de pessoas do mundo inteiro já enfrentam escassez e racionamento, e o problema tende a aumentar. Parece inacreditável, mas o mundo atual está prestes a enfrentar uma grande crise no abastecimento de água. Atualmente, 29 países já têm problemas com a falta de água, entre eles, pode-se citar o Orien- te Médio; China, Índia e o Norte da África, e até 2050, as previsão da Organização Mundial da Saúde (OMS) é que mais de cinquenta países enfrentarão crise no abastecimento de água. É compreensível, esta crise deve-se a determinados fatores, como o crescimento da população, atividades econômicas e desperdícios domésticos por mau uso deste líquido, tratado na maioria das vezes como ilimitado [30].

Para minimizar ou talvez solucionar a escassez da água, os cientistas pesquisam três saídas, visando aumentar a oferta de água: o aproveitamento das geleiras e dos icebergs; o uso dos estoques subterrâneos, ainda não totalmente explorados; e a dessalinização da água do mar, ou seja, o processo de transformação da água salgada em água

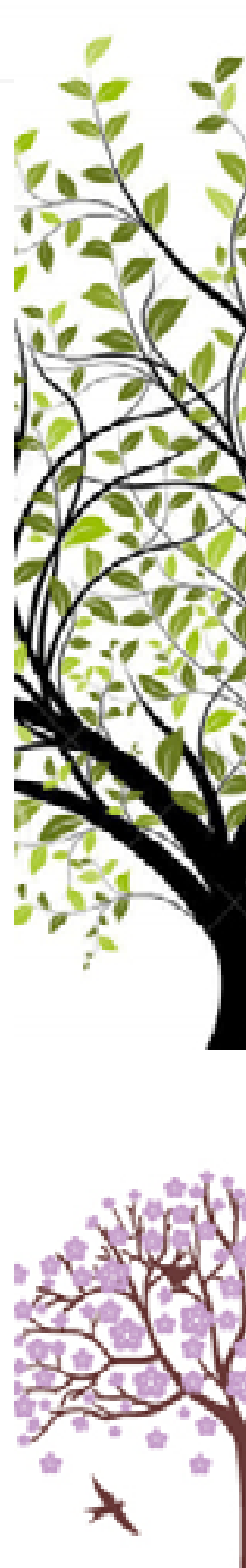


doce. Entretanto, nenhuma dessas soluções é corriqueira e economicamente viável, o que as torna impraticáveis para a maioria dos países que enfrentam o problema. Sabe-se que o Brasil é um país privilegiado, possui $20 \%$ de toda água doce da superfície da Terra, porém, também enfrenta grandes problemas de abastecimento, pois 80\% dessa água esta localizada na Amazônia, região mais desabitada do país. Os 20\% restantes é distribuído desigualmente pelo restante do país e precisa atender 95\% da população. Além do

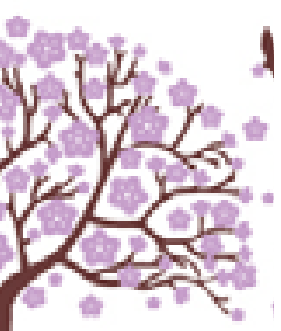

- mais, a grande maioria dessa água está contaminada, sendo que os grandes vilões são os esgotos domésticos, a indústria e os inúmeros resíduos tóxicos descartados em rios mananciais sem o mínimo controle [52].
O alerta é da ONU, que já traça um cenário atual bastante difícil: mais de um bilhão de pessoas, cerca de $18 \%$ da população mundial estão sem acesso a uma quantidade mínima de água de boa qualidade para consumo. A questão é que, mantidos os atuais padrões de consumo e de danos ao meio ambiente, o quadro pode piorar muito e calcula-se que, em 2025, dois terços da população global 5,5 bilhões de pessoas poderão ter dificuldade de acesso à água potável; em 2050, já seria cerca de 75\% da humanidade. 0 drama diz respeito à sede e à escassez de água para cozinhar, tomar banho e o cultivo de agricultura, mas também à disseminação de doenças causadas pela ausência de tratamento da água, como diarreia entre outras [53].
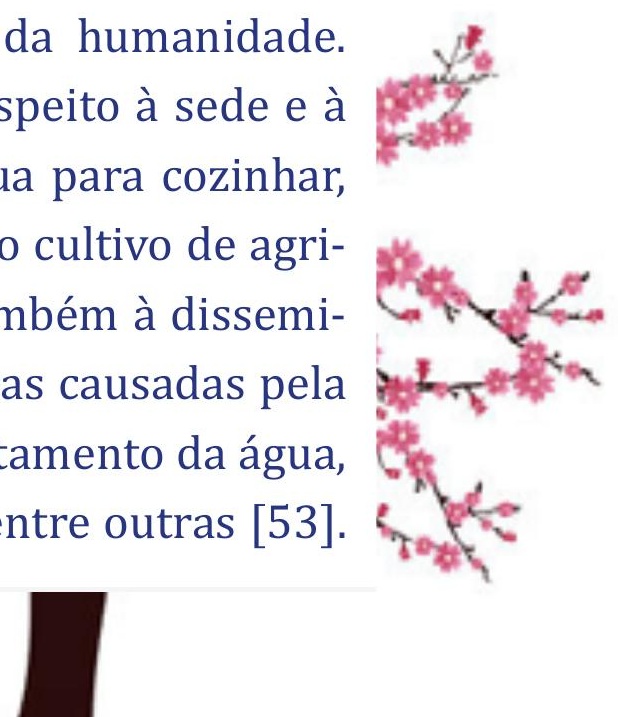


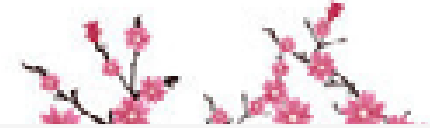

A principal causa da escassez de

danças no uso econômico, tanto - água potável também é relacioagrícola quanto industrial, tamnada ao mau uso. Estima-se que, bém podem cortar o consumo. de cada 100 litros de água própria para consumo, 60 se perParte importante, porém, cabem aos governos, responsáveis cam em razão de maus hábitos ou de distribuição ineficiente. A agropecuária é a atividade que por investimentos para resolver problemas estruturais [54]. As possibilidades de redução : mais consome água no mundo. Calcula-se que as plantações de emissões dos gases de efeito estufa são identificadas e esturespondam por $69 \%$ de seu dadas cuidadosamente, invesuso. A indústria utiliza $21 \%$ e o consumo doméstico responde por $10 \%$. 0 uso consciente esta relacionada à popularização crescente da idéia do uso sustentável dos recursos naturais. Medidas simples e ao alcance de todos, como reduzir o tempo de banho e fechar a torneira ao escovar os dentes ou ensaboar a louça, podem resultar em até um terço de economia na utilização do uso doméstico. As mutimentos, custos operacionais, riscos, e receitas. Com base no Inventário de Emissões de Gases de Efeito Estufa (GEE), estas oportunidades são identificadas e analisadas de forma a permitir a tomada de decisões a respeito da sua implantação [55]. Para reduzir o impacto da poluição atmosférica no meio ambiente, evitando maior aquecimento global, devem-se criar legislações mais rigorosas

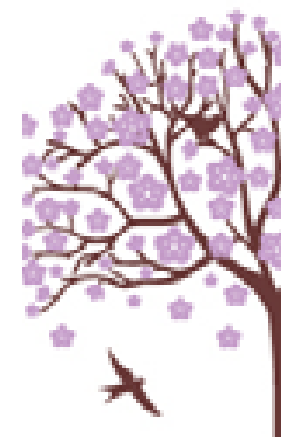




\section{antipoluição, que determi-}

ne as fábricas instalarem filtros nas suas chaminés, e a tratar os seus efluentes sólidos e gasosos [56].
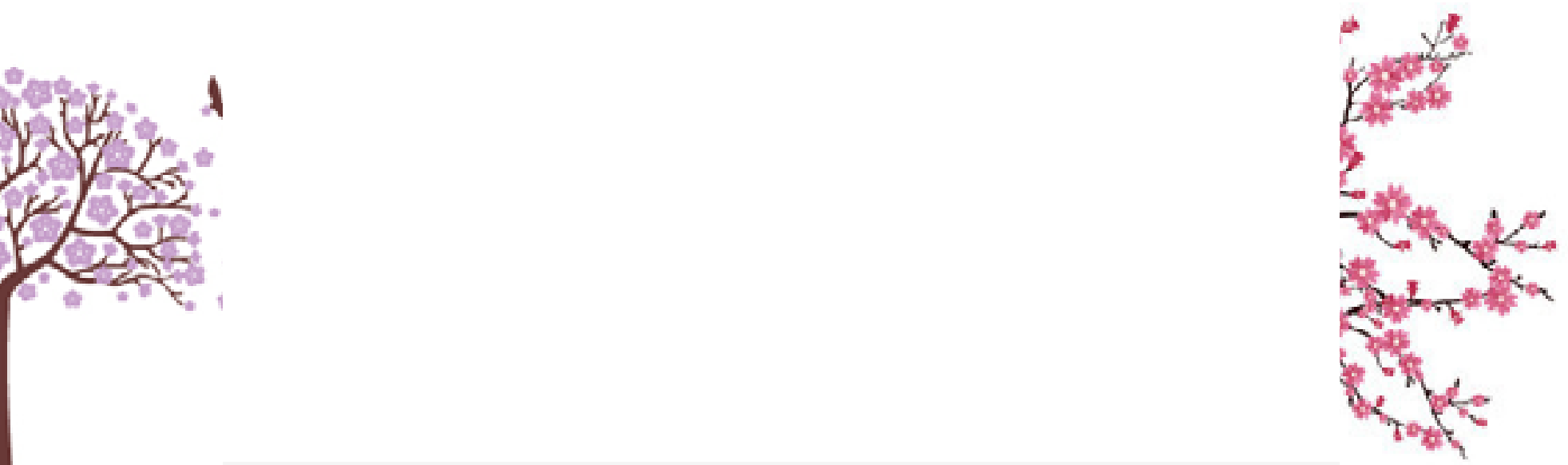


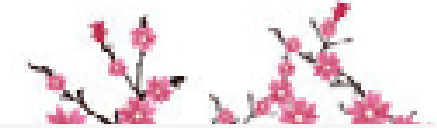

\section{EFLUENTES GASOSOS}

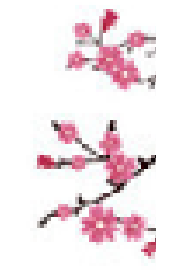

A poluição do ar nos grandes centros urbanos é um dos maiores problemas ambientais da atualidade, com implicações graves na saúde da população. A concentração de poluentes no ar é resultado das emissões proveniente de fontes estacionarias como indústrias e veículos automotores conjugados a outros fatores, tais como clima, geografia, uso do solo, distribuição e tipologia das fontes, condições de emissão e dispersão local dos poluentes. 0 monitoramento do ar subsidia ação de fiscalização, controle e gestão da qualidade do ar, tais como a melhoria dos transportes públicos e a introdução de tecnologia menos poluente [57]. Na Resolução CONAMA no 03 de 28/06/1990 estão descritas os padrões para todo o território nacional. Os poluentes considerados foram: partículas totais em suspensão (PTS), dióxido de enxofre (SO2), monóxido de carbono (CO), ozônio (03), fumaça, dióxido de nitrogênio (NO2). Foram estabelecidos Padrões Primários, destinados à proteção da saúde publica e Padrões Secundários, para a proteção do meio ambiente em geral e do bem-estar da população, bem como os métodos de referencias usados nas medições [58].

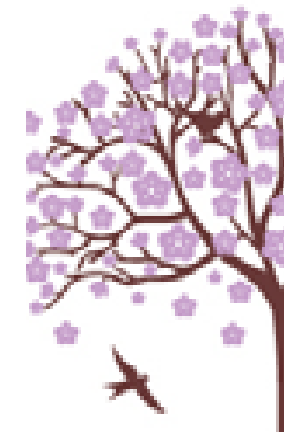


Monóxido de Carbono (CO)

Gás incolor, inodoro e insípido é o poluente característico dos grandes centros urbanos. Sua fonte principal são os veículos automotores, mas estão presentes em qualquer combustão (em maior ou menor quantidade), dependendo de sua qualidade. A presença de CO indica uma combustão incompleta. Seu principal efeito é a redução da habilidade do sistema circulatório de transportar oxigênio, devido a sua maior afinidade pela hemoglobina do que o oxigênio, formando a carboxihemoglobina, ao invés da oxihemoglobina que leva oxigênio para os tecidos [59].

\section{Dióxido de Enxofre (S02)}

Gás incolor, que provém, principalmente da queima de combustíveis fósseis, contém enxofre, que na combustão se transforma em óxido de enxofre, sendo estes, constituídos principalmente por S02. É um gás irritante das vias respiratórias, e é capaz de produzir broncoconstrição.

\section{Dióxido de Nitrogênio (NO2)}

Gás, cuja fonte principal de emissão é a combustão, onde o nitrogênio do combus63 tível se associa ao oxigênio do ar, nas altas temperaturas da câmara de combustão. Os efeitos são os aumentos da resistência à passagem de ar nas vias respiratórias, danos ao transporte normal de gases entre o sangue e os pulmões.

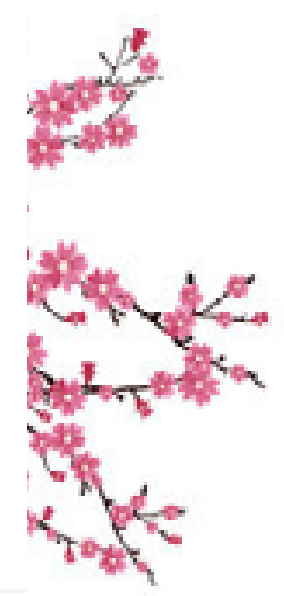




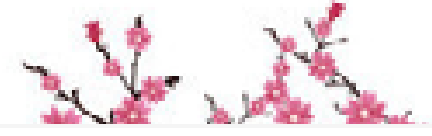

Hidrocarbonetos e Outros

- Compostos Orgânicos Voláteis

Os hidrocarbonetos gasosos como um todo não causam preocupação com relação a efeitos diretos à saúde. Mas são importantes, de uma forma indireta, pois participam da rea-

: ção fotoquímica, produzindo outros compostos agressivos como os aldeídos (aldeído fórmico e a acroleína). Esses compostos causam desde irritação dos olhos e vias respiratórias, até pneumonia e em altas concentrações, são compostos letais. Alguns hidrocarbonetos e outros compostos orgânicos também causam impacto direto à saúde, como o benzeno, por exemplo. Esse composto provém principalmente da emissão de carros a gasolina, do armazenamento de gasolina, de refinarias de pe- tróleo e processo de produção de algumas indústrias químicas. Seus efeitos a saúde estão relacionados com o processo de formação do sangue. Exposição prolongada pode resultar em redução substancial do número de células vermelhas [60].

Ozônio (03) e Outros Oxidantes Fotoquímicos

"Oxidantes

fotoquímicos" é a denominação que se dá à mistura de poluentes secundários formados pelas reações entre os óxidos de nitrogênio e compostos orgânicos voláteis, na presença de luz solar, sendo estes últimos liberados na queima incompleta e evaporação de combustíveis e solventes. 0 principal produto desta reação é o ozônio, por isso mesmo utilizado como parâmetro indica-

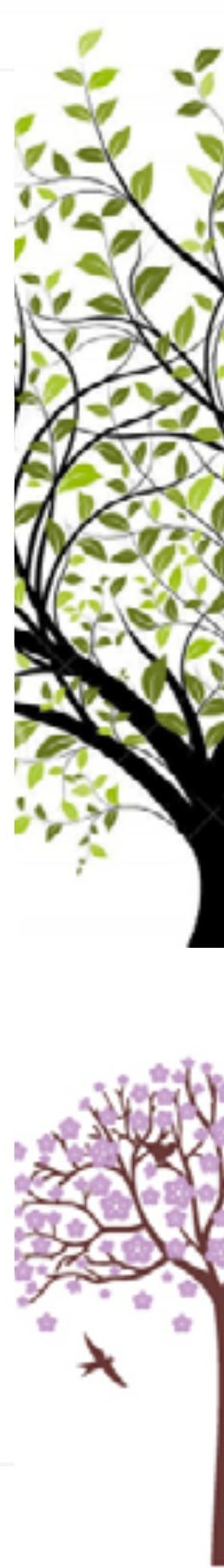


dor da presença de oxidantes fotoquímicos na atmosfera. Tais poluentes formam a chamada névoa fotoquímica ou "smog fotoquímico", que possui este nome porque causa na atmosfera diminuição da visibilidade.

Além de prejuízos à saúde, o ozônio pode causar danos à vegetação. É sempre bom ressaltar que o ozônio encontrado na faixa de ar próxima do solo, onde respiramos chamado de "mau ozônio", é tóxico. Entretanto, na estratosfera (a cerca de $25 \mathrm{~km}$ de altitude) o ozônio tem a importante função de proteger a Terra, como um filtro, dos raios ultravioletas emitidos pelo Sol [61].

\section{Material Particulado (MP)}

0 material particulado presente na atmosfera é de origem diversificada e sua com- posição e concentração, dependem do período, local e hora considerados. E os efeitos à saúde dependem dessa composição e concentração [62]. Sob a denominação geral de Material Particulado (MP) se encontra um conjunto de poluentes constituídos de poeiras, fumaças e todo tipo de material sólido e líquido que se mantém suspenso na atmosfera por causa de seu pequeno tamanho. As principais fontes de emissão de particulado para a atmosfera são: veículos automotores, processos industriais, queima de biomassa, ressuspensão de poeira do solo, entre outros. 0 material particulado pode também se formar na atmosfera a partir de gases como dióxido de enxofre (SO2), óxidos de nitrogênio (NOx) e compostos orgânicos voláteis

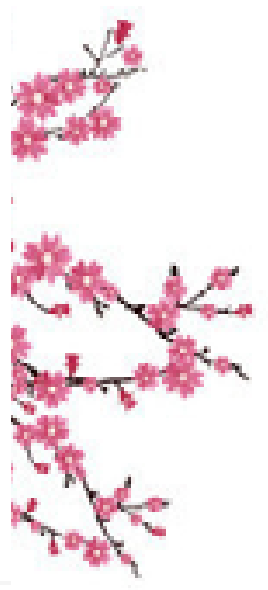




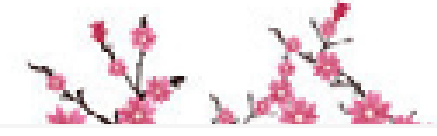

(COVs), que são emitidos princi-

_. palmente em atividades de combustão, transformando-se em t. partículas como resultado de reações químicas no ar.O tamanho das partículas esta diretamente associado ao seu potencial para causar problemas à saúde, sen-

: do que quanto menores, maiores os efeitos provocados [61].

66
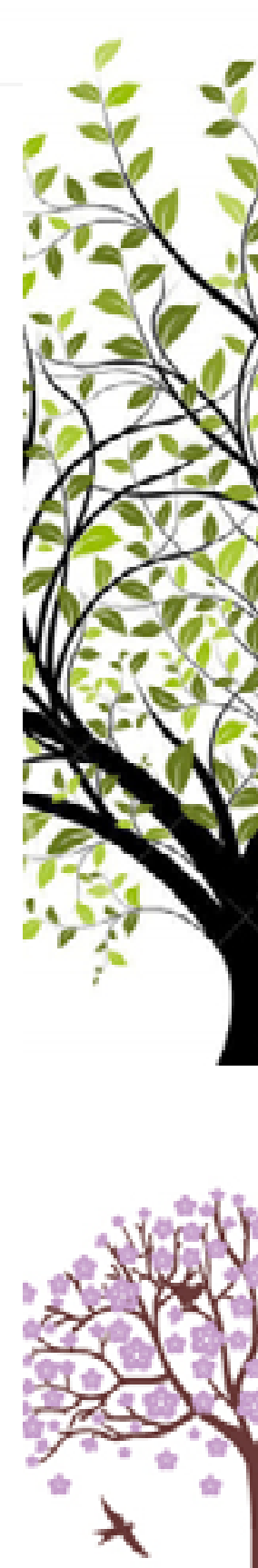


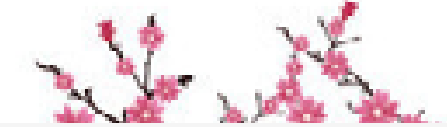

EFLUENTES LÍQUIDOS

O padrão de desenvolvimento econômico vigente na maioria dos países está associado diretamente ao crescimento industrial e consequentemente, ao aumento de degradação ambiental. A intensificação na operação de certos ramos de atividades, como química, petroquímica, metalmecânica, madeira, papel e celulose, material de transportes e minerais, todos com uma forte carga de impactos sobre o meio ambiente incorporando padrões tecnológicos avançados para a base nacional, mas ultrapassados no que se refere à relação com o meio ambiente que, neste caso, são escassos de elementos tecnológicos de tratamento, reciclagem e reprocessamento.
Todo processo industrial gera resíduos, muitas vezes tóxicos e perigosos, não sendo possível simplesmente descartar esses materiais na natureza sem causar danos à saúde e ao meio ambiente. A solução dos problemas do acondicionamento, coleta, transporte, tratamento e/ ou disposição final dos resíduos perigosos está intimamente ligada à sua composição [63]. Uma das soluções para os problemas gerados é a reciclagem de resíduos. A reciclagem de resíduos pela indústria vem se consolidando como uma prática importante para a sustentabilidade seja atenuando o impacto ambiental gerado pelo setor ou reduzindo os custos. Segundo a Norma Brasileira NBR 9800/1987, efluente líquido industrial é o despejo líquido

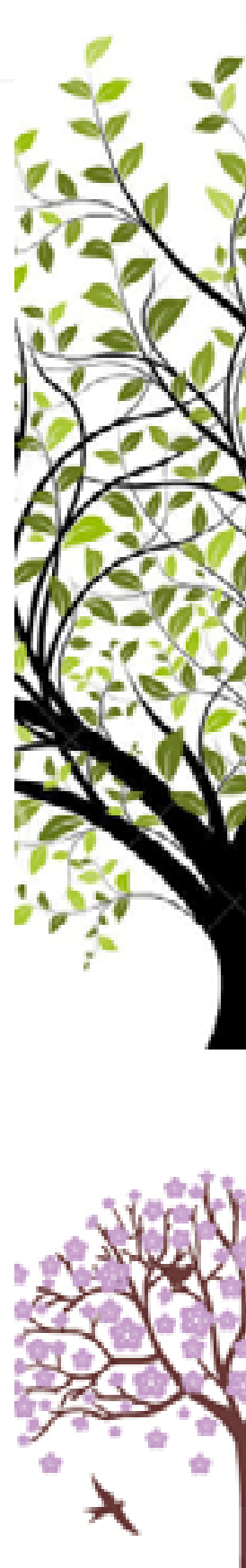


proveniente do estabelecimento industrial, compreendendo emanações de processo industrial, águas de refrigerações poluídas, águas pluviais poluídas e esgoto doméstico [64]. Na busca da minimização dos problemas ambientais a utilização de rejeitos em processos industriais tem uma grande importância, haja vista que diminui o volume dos depósitos e contribui significativamente para a redução na extração da matéria-prima. Atualmente vem sendo ampliado o aproveitamento de rejeitos domiciliares e industriais, dentro de uma visão que trata estes poluentes como matérias-primas importantes para aplicações nobres e com maior valor agregado [65]. Segundo definição da Comissão Mundial de Desenvolvimen- to e Meio Ambiente (do inglês WCED, 1987), a sustentabilidade baseia-se no "desenvolvimento de acordo com as necessidades do presente sem comprometer a capacidade das gerações futuras de satisfazer suas próprias necessidades". Portanto, um projeto realmente sustentável deve considerar seu impacto sobre as gerações futuras, onde os principais aspectos a se69 rem considerados no ambiente construído são os usos da energia, água e materiais. (WCED, 1987; CMMD, 1991) [66].

\section{Efluente Líquido}

\section{Industrial}

A grande diversidade das atividades industriais ocasiona durante o processo produtivo, a geração de efluentes, os quais podem poluir/contaminar o solo
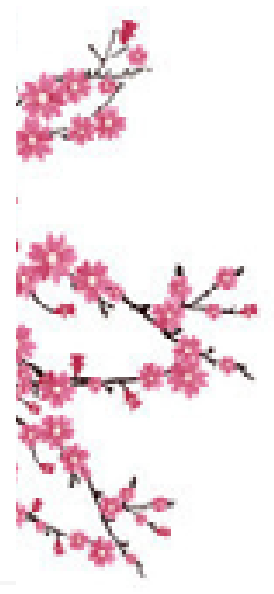


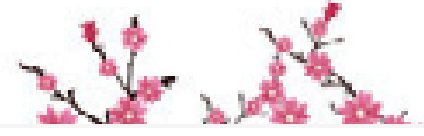

geram efluentes com poder impactante nesses dois ambientes.

Em um primeiro momento, é possível imaginar serem simples os procedimentos e atividades de controle de cada tipo de

: efluente na indústria. Todavia, as diferentes composições físicas, químicas e biológicas, as variações de volumes gerados em relação ao tempo de duração do processo produtivo, a potencialidade de toxicidade e os diversos pontos de geração na mesma unidade de processamento recomendam que os efluentes sejam caracterizados, quantificados e tratados e/ou acondicionados, adequadamente, antes da disposição final no meio ambiente. A escassez de água, o alto custo do tratamento de efluentes e a iminente cobrança pelo uso e descarte da água vêm preocupando a sociedade e incentivando pesquisas na área de otimização do uso da água e minimização de efluentes. 0 setor industrial é um dos setores que mais tem se preocupado e se empenhado em encontrar soluções para este problema, pois vivenciam os dois problemas ao mesmo tempo, a alta demanda de água e o tratamento dos efluentes gerados [67]. Por muito tempo não existiu a preocupação de caracterizar a geração de efluentes líquidos industriais e de avaliar seus impactos no meio ambiente. No entanto, a legislação vigente e a conscientização ambiental fazem com que algumas indústrias desenvolvam atividades para quantificar a vazão e determi-

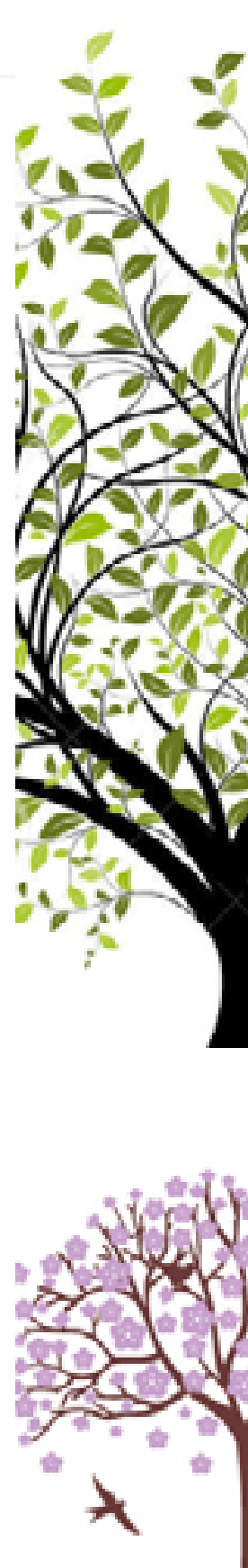


nar a composição dos efluentes industriais. As características físicas, químicas e biológicas do efluente industrial são variáveis com o tipo de indústria, com o período de operação, com a matéria-prima utilizada, com a reutilização de água. Com isso, o efluente líquido pode ser solúvel ou com sólidos em suspensão, com ou sem coloração, orgânico ou inorgânico, com temperatura baixa ou elevada. Entre as determinações mais comuns para caracterizar a massa líquida estão às determinações físicas (temperatura, cor, turbidez, sólidos.), as químicas $(\mathrm{pH}$, alcalinidade, teor de matéria orgânica, metais.) e as biológicas (bactérias, protozoários, vírus). Estes padrões estão estabelecidos na Resolução CONAMA n 357 de 2004[58]. 0 conhecimento da vazão e da composição do efluente industrial possibilita a determinação das cargas de poluição / contaminação, o que é fundamental para definir o tipo de tratamento, avaliar o enquadramento na legislação ambiental e estimar a capacidade de autodepuração do corpo receptor. Desse modo, é preciso quantificar e caracterizar os efluentes, para evitar danos ambientais, demandas legais e prejuízos para a imagem da indústria junto à sociedade. Assim, as indústrias estão buscando caminhos para diminuir o volume de resíduos gerados com a implantação de estratégias de recuperação e de reuso (EPA, 2002). Há inúmeras vantagens, diretas e indiretas, com a implantação de estratégias de recuperação. Afirma que o alcance da sustentabilidade está

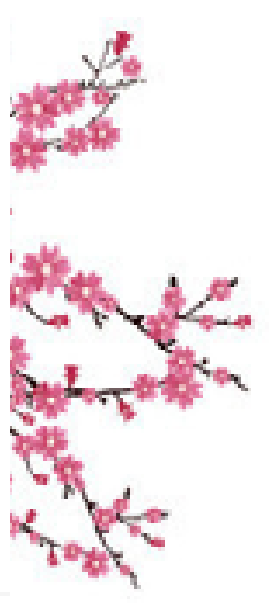




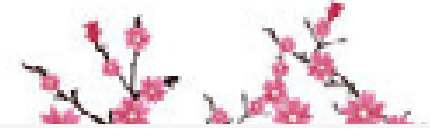

associado à estabilização ou re-

rentes da otimização do pro\ dução da carga ambiental [68]. cesso, da conscientização e do O desenvolvimentosustentável, a envolvimento dos funcionários.

prevenção e controle integrados da poluição, são palavras-chave para uma nova abordagem, visando a proteção ambiental. Atualmente se considera indissociá: vel do conceito de produtividade, a minimização de efluentes e a racionalização do consumo de matérias-primas. São diversos os benefícios advindos da implantação de programas de reuso e reaproveitamento:

\section{Efluente Líquido \\ Doméstico}

Todos os elementos que são rejeitados do ambiente domiciliar são efluentes domésticos sendo os sólidos classificados como lixo e suas sub qualificações (orgânico, inorgânico) e os líquidos, semi-liquídos, amorfos, semi-sólidos e alguns tipos de sólidos presentes - Redução dos custos em meio aquoso como esgoto. de implantação e operação de estações de tratamento; A palavra esgoto costuma ser usada para definir tanto a tubu- Possibilidade de au- lação condutora das águas servimentar a produção sem am- das de uma comunidade, como pliar as instalações para também o próprio líquido que tratamento de efluentes; flui por estas canalizações. Hoje - Aumento de produtivida- este termo é usado para caractede e redução de perdas decor- rizar os despejos provenientes

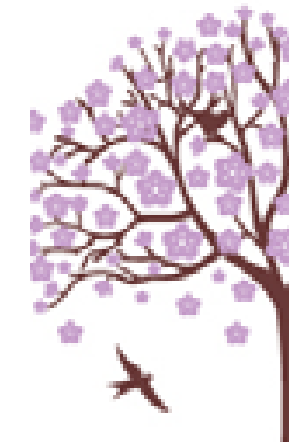


das diversas modalidades do uso e da origem das águas, tais como as de uso doméstico, comercial, industrial, as de utilidades públicas, de áreas agrícolas, de superfície, de infiltração, pluviais, e outros efluentes sanitários [69]. Os esgotos domésticos provêm principalmente de residências, edifícios comerciais, instituições ou quaisquer edificações que contenham instalações de banheiros, lavanderias, cozinhas, ou qualquer dispositivo de utilização da água para fins domésticos. Compõem-se essencialmente da água de banho, urina, fezes, papel, restos de comida, sabão, detergentes, águas de lavagem [70]. Os esgotos domésticos respondem por cerca de $85 \%$ da poluição das águas, e os industriais são responsáveis pelos 15\% res- tantes. Por outro lado, os dados revelam que apenas 5\% da população da região Norte é servida por rede de esgotos e, na região Sudeste, o mesmo índice não ultrapassa os 41\%. Apesar dos grandes avanços na área do tratamento de efluentes, muitas cidades ainda adotam sistemas simplificados de tratamento por fossas sépticas e lagoas de estabilização, que podem provocar a poluição das águas superficiais e subterrâneas. Ademais, as lagoas de estabilização ocupam áreas enormes e podem gerar um passivo ambiental significativo [71].

\section{Reutilização de}

\section{Efluentes Líquidos}

Toda vida existente na Terra nasceu da água e poderá desaparecer pela própria água, por ser ela um dos elementos

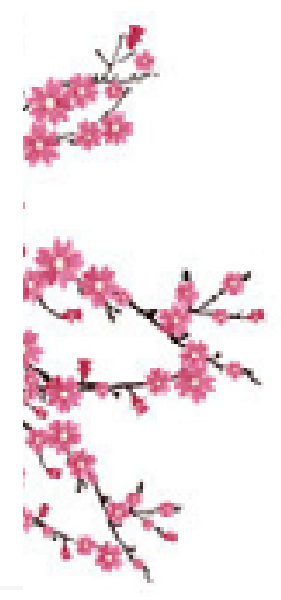




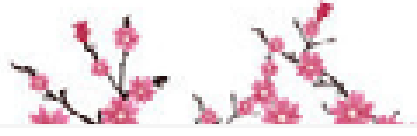

indispensáveis ao ecossistema $-$ chamado Planeta Terra. No Planeta, 97\% de toda água existente são salgadas; do restante, água doce, apenas 0,03\% estão fáceis e diretamente disponíveis para o uso do homem nos rios, lagos e subsuperfícies $[67,71]$.

Levantamentos preliminares efetuados pela CETESB apontam nada menos que 2.300 áreas potencialmente contaminadas em função das atividades que são desenvolvidas, sem incluir os postos de gasolina, que somam mais de 2.000 e dos quais 45 já estão comprometidos com vazamentos. Isto só na região metropolitana de São Paulo [72]. 0 homem é o grande consumidor de água doce, quer direta ou indiretamente. Esta água faz parte integrante dos ecossistemas devido à sua participação nos ciclos bioquímicos. Em números aproximados, tem-se que o consumo de uma família na cidade é seis vezes maior que de outra família no campo; uma descarga sanitária equivale a doze litros, e para encher-se uma banheira ou se lavar uma quantidade de roupas na máquina, o consumo é de 120 litros, [67]. Mas, se compararmos esses consumos, ditos diretos, com os indiretos, a situação é alarmante: para produzir um simples pãozinho são necessários 400 litros de água, considerar-se as necessidades desde o trigo que lhe deu origem. Um quilo de carne corresponde a 18.000 litros de água que foram fornecidos direta ou indiretamente ao animal que lhe deu origem até a carne estar pronta para o consumo. A produção de uma tonelada de

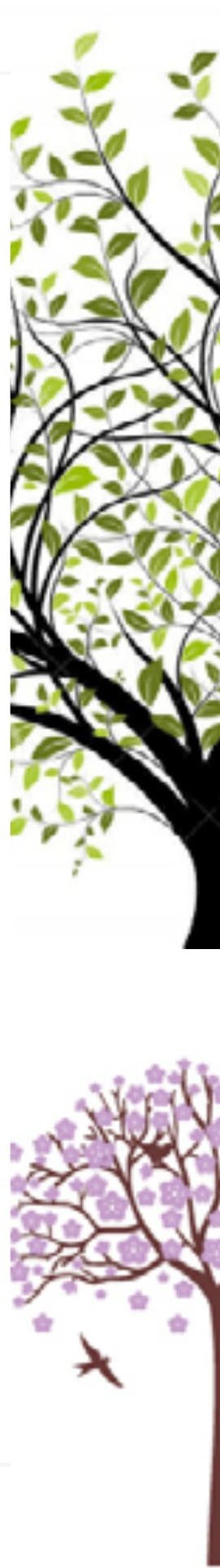




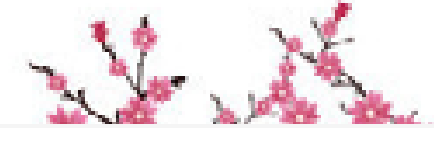

\section{RESÍDUOS SÓLIDOS}

Os resíduos sólidos é um tema central quando se fala em sustentabilidade e na Agenda 21 estão estabelecidas diretrizes para o gerenciamento desses resíduos sólidos. As formas tradicionais de abordagem sobre o assunto devem ser atreladas a uma mudança de estilo de vida, com mudanças na forma de consumo, nos pa* drões de produção e consequentemente na geração de resíduos. A denominação de resíduos é um tema polêmico e para muitos a palavra resíduo e lixo querem dizer a mesma coisa por não conhecerem as diversas técnicas de tratamento, reutilização e disposição final destes resíduos. Os progressos da humanidade aumentaram a qualidade e a duração da vida. A contrapartida é um padrão de consumo e demanda de matérias-primas, que de certa forma pode comprometer a qualidade de vida das gerações futuras. 0 crescimento sustentável espera que o homem use a capacidade de transformar as matérias, porém de forma sustentável [75]. Vamos definir resíduo sólido, segundo a NBR 10004/87: ? Resíduos nos estados sólido e semi-sólido, que resultam de atividades da comunidade, de origem: industrial, doméstica, hospitalar, comercial, agrícola, de serviços e de varrição. Consideram-se também resíduos sólidos os lodos provenientes de sistemas de trata-

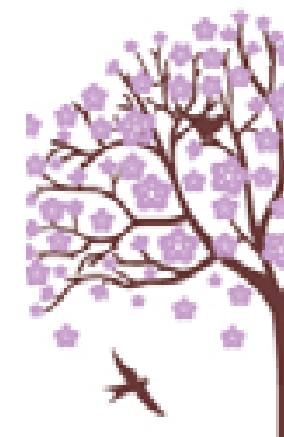




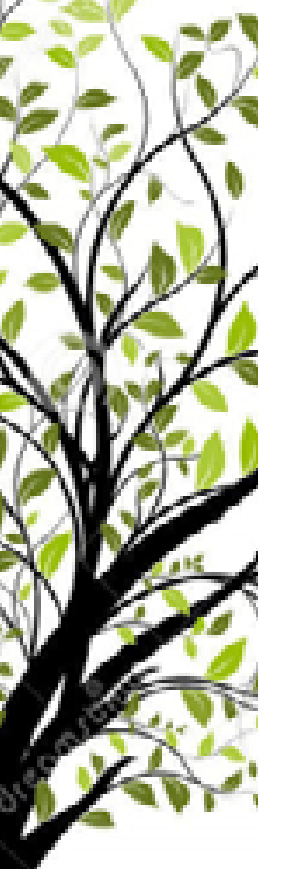

mento de água, aqueles gerados em equipamentos e instalações de controle de poluição, bem como determinados líquidos, cujas particularidades tornem inviável o seu lançamento na rede pública de esgotos ou corpo d'água, ou exijam para isso soluções técnicas e economicamente inviáveis em face da melhor tecnologia disponível [76]. 0 Projeto de Lei que Institui a Política Nacional de Resíduos Sólidos classifica os resíduos segundo sua origem em: Resíduos sólidos urbanos: resíduos sólidos gerados por residências, domicílios, estabelecimentos comerciais, prestadores de serviços e os oriundos dos serviços públicos de limpeza urbana e manejo de resíduos sólidos, que por sua natureza ou composição te- nham as mesmas características dos gerados nos domicílios; Resíduos sólidos industriais: resíduos sólidos oriundos dos processos produtivos e instalações industriais, bem como os gerados nos serviços públicos de saneamento básico, excetuando-se os relacionados na alínea "c" do inciso I do Art. $3^{\circ}$ da Lei $n^{\circ}$ 11.445, de 2007; Resíduos sólidos de serviços de saúde: resíduos sólidos oriundos dos serviços de saúde, conforme definidos pelo Ministério da Saúde em regulamentações técnicas pertinentes; Resíduos sólidos rurais: resíduos sólidos oriundos de atividades agropecuárias, bem como os gerados por insumos utilizados nas respectivas atividades; e resíduos sólidos especiais ou diferenciados: aqueles que por seu vo-

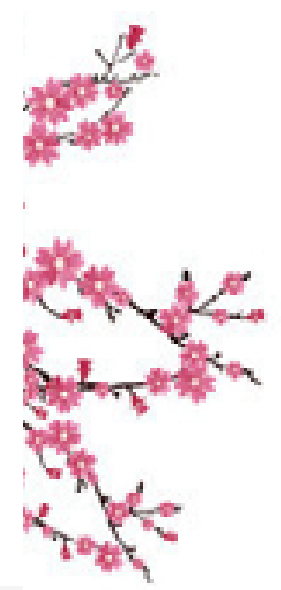




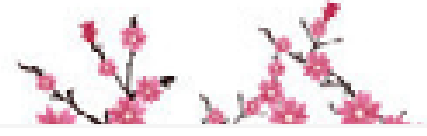

w mentos especiais ou diferenciados para o manejo e a disposição final dos rejeitos, considerando os impactos negativos e os riscos à saúde e ao meio ambien: te; e segundo sua finalidade em: Resíduos sólidos reversos: resíduos sólidos restituíveis, por meio da logística reversa, visando o seu tratamento e reaproveitamento em novos produtos, na forma de insumos, em seu ciclo ou em outros ciclos produtivos; e Rejeitos: resíduos sólidos que, depois de esgotadas todas as possibilidades de tratamento e recuperação por processos tecnológicos acessíveis e disponíveis, não apresentem outra possibilidade que não a disposição final ambientalmente adequada.

\section{Sustentabilidade e \\ Resíduos Sólidos}

Os Projetos de Lei que institui a Política Nacional de Resíduos Sólidos define: Consumo sustentável: o consumo de bens e serviços, de forma a atender às necessidades das atuais gerações e permitir melhor qualidade de vida, sem comprometer o atendimento das necessidades e aspirações das gerações futuras. Destinação final ambientalmente: adequada técnica de destinação ordenada de rejeitos, segundo normas operacionais específicas, de modo a evitar danos ou riscos à saúde pública e à segurança, minimizando os impactos ambientais adversos. Logística reversa: instrumento de desenvolvimento econômico e social, caracterizada por

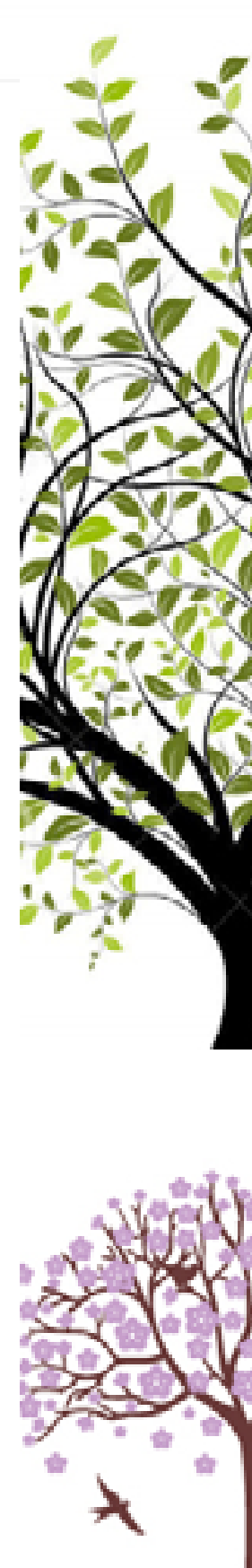


um conjunto de ações, procedimentos e meios, destinados a facilitar a coleta e a restituição dos resíduos sólidos aos seus geradores para que sejam tratados ou reaproveitados em novos produtos, na forma de novos insumos, em seu ciclo ou em outros ciclos produtivos, visando a não geração de rejeitos. Tecnologias ambientalmente saudáveis: tecnologias de prevenção, redução ou eliminação de resíduos sólidos ou poluentes, propiciando à redução de desperdícios, a conservação de recursos naturais, a redução ou eliminação de substâncias tóxicas presentes em matérias-primas ou produtos auxiliares, a redução da quantidade de resíduos sólidos gerados por processos e produtos e, conseqüentemente, a redução de poluentes lança- dos para o ar, solo e águas [77].

\section{Ações Sustentáveis}

Hoje o assunto central em sustentabilidade é mudança de hábitos e atitudes e não tanto as tecnologias desenvolvidas para se manter a sustentabilidade. Não basta poluir e tratar é necessário não poluir. Existem diversos movimentos e ações organizadas ou não em prol de pequenas ações sustentáveis para o dia-a-dia dos cidadãos. Dentre estas organizações podemos citar o site www.cidadaosustentavel.com. br, apoiado pelo Ministério do Meio Ambiente. Vindo ao encontro da proposta dos 3R's: redução, reutilização e reciclagem [referência....hoje é falado em 5R's (Reduzir, Reutilizar, Reciclar, Reeducar, Replanejar)

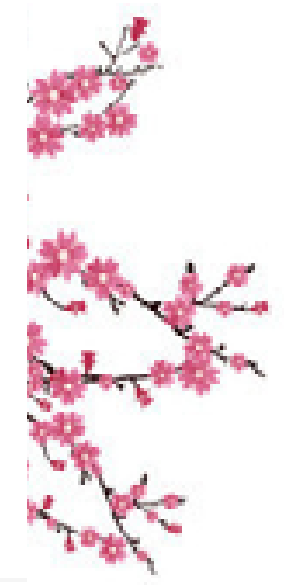

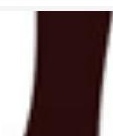




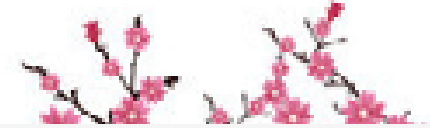

Podemos chamar de redução na - fonte, a redução do uso de matérias primas (menor quantidade de matérias irá produzir menor quantidade de resíduos), menor uso de energia e escolha criteriosa dos matérias empregados na fabricação. 0 reaproveitamento

: ou reutilização de resíduos está ligado à idéia de valorização, ou seja, obter algum ganho com materiais que seriam descartados. 0 reaproveitamento pode ser pela recuperação, como por exemplo, a recuperação da prata nos filmes de raios $\mathrm{X}$ ou pela reutilização por meio do reaproveitamento direto, como é o caso das garrafas retornáveis. A reciclagem é uma forma particular e consagrada de reaproveitamento de matérias primas, tais como papel, plásticos, latas de alumínio e de aço, pneus, vidro,

em que é produzida uma nova quantidade de materiais a partir do material captado no mercado e reprocessamento para ser comercializado. Em alguns casos, não há nenhuma diferença entre o produto gerado a partir de reciclagem e aquele gerado a partir de matéria prima nova, havendo, via de regras grandes economias em energia e matéria prima [78]. Nesta última abordagem podemos citar a importância social das cooperativas e catadores de materiais recicláveis. Hoje, esta atividade emprega milhares de pessoas. Segue a descrição de alguns exemplos de materiais do lixo comum que podem ser reciclados, mencionados pelo Instituto de Biociências da Universidade de São Paulo [79]. PAPEL: Aparas de papel, jor-

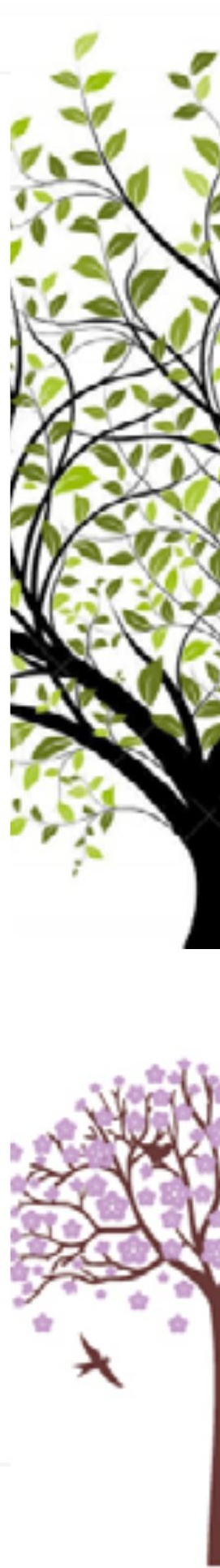


nais, revistas, caixas, papelão, frascos, garrafas de bebipapel de fax, formulários de das, copos, embalagens. computador, folhas de caderno, ORGÂNICOS: Restos de cocartolinas, cartões, rascunhos mida em geral, cascas de fruescritos, envelopes, fotocópias, tas, casca de ovo, sacos de folhetos, impressos em geral; chá e café, folhas, caules, floPLÁSTICOS: Tampas, potes de res, aparas de madeira, cinzas. alimentos (margarina), frascos, utilidades domésticas, embalagens de refrigerante, garrafas de água mineral, recipientes para produtos de higiene e limpeza, PVC, tubos e conexões, sacos plásticos em geral, peças de brinquedos, engradados de bebidas, baldes. Embalagens de TetraPak® podem ser separadas juntamente com o plástico. METAIS: Latas de alumínio, latas de aço (latas de óleo, sardinha, molho de tomate), tampas, ferragens, canos, esquadrias e molduras de quadros. VIDRO: Tampas, potes,

\section{Resíduos Industriais}

Os resíduos industriais podem ser: cinzas, lodos, óleos, metais, vidros, plásticos, orgânicos etc. e de acordo com as suas características, são classificados segundo a Norma 10.004 da ABNT, como: classe I - perigosos; de classe II - não inertes; ou de classe III - inertes. Na Agenda 21, os programas considerados importantes para o equacionamento da poluição por resíduos perigosos são: promover a minimização da geração de resíduos perigosos; promover

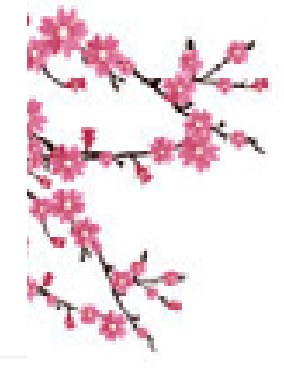




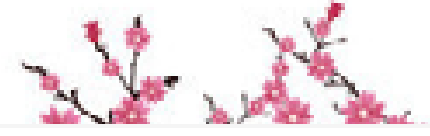

- tucional para o gerenciamento de resíduos perigosos; promover e fortalecer a cooperação internacional para o gerenciamento da movimentação de resíduos perigosos entre fronteiras; e impedir o tráfico internacio: nal ilegal de resíduos perigosos, sempre objetivando reduzir ou eliminar os riscos para a saúde pública e para o ambiente [80]. As principais técnicas de tratamento destes resíduos, empregadas atualmente são: - Aterros industriais; - Incineração em fornos de produção de cimento - este processamento exige um nível de especialização capaz de assegurar a correta identificação dos resíduos que possam ser incinerados nos fornos de cimento, as melhores condições de acumulação

e pré-tratamento e o real conhecimento do processo de queima;

Queima em incineradores de forno rotativo - este sistema possui um controle da poluição ambiental; - Tratamento químico para neutralização e estabilização de resíduos; - Injeção em poços profundos (deep well). Uma técnica que merece destaque como medida sustentável é o reprocessamento e destinação final de resíduos industriais que a Empresa SUZAQUIM Indústrias Químicas Ltda. realiza em pilhas, baterias e resíduos tecnológicos para a produção de óxidos e sais metálicos. 0 processo produtivo de sais e óxidos metálicos consiste em secagem e calcinação das matérias-primas e/ou resíduos indus-

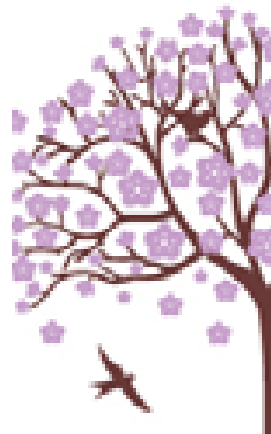


triais, reação química, moagem, balanceamento, formulação e misturas. A legislação ambiental vincula o gerador de resíduos às possíveis conseqüências de agressão ao meio ambiente. No procedimento executado pela SUZAQUIM, essa preocupação deixa de existir, pois os resíduos industriais sofrem a qualificada química de reconsumo, ou seja, lavagens e tratamentos térmicos, como separação via reação química, queima em forno calcinador (oxidação), moagem e redução do teor de umidade (secagem). Os possíveis poluentes atmosféricos são controlados por meio de lavadores de gases, não havendo sobra de resíduos e/ou descarte de efluentes líquidos, que depois de tratados são reutilizados. A destinação final dos resíduos é totalmente exaurida no reprocessamento, processo este, possivelmente, sem similar no Brasil [81]. O Grupo Santander Brasil, por meio de seu Programa de Reciclagem de Pilhas e Baterias, realiza o recolhimento de pilhas e baterias e envia para a recicladora Suzaquim Indústrias Químicas Ltda. As pilhas e baterias são desencapadas e seus metais queimados em fornos industriais de alta temperatura, dotados de filtros que impedem a emissão de gases poluentes. Nesse processo são obtidos sais e óxidos metálicos, que são utilizados na indústria de refratários, vidros, tintas, cerâmicas e químicas em geral, sem riscos às pessoas e ao ambiente [82]. Pilhas e baterias representam hoje um sério problema ambiental, são produzidas a cada ano
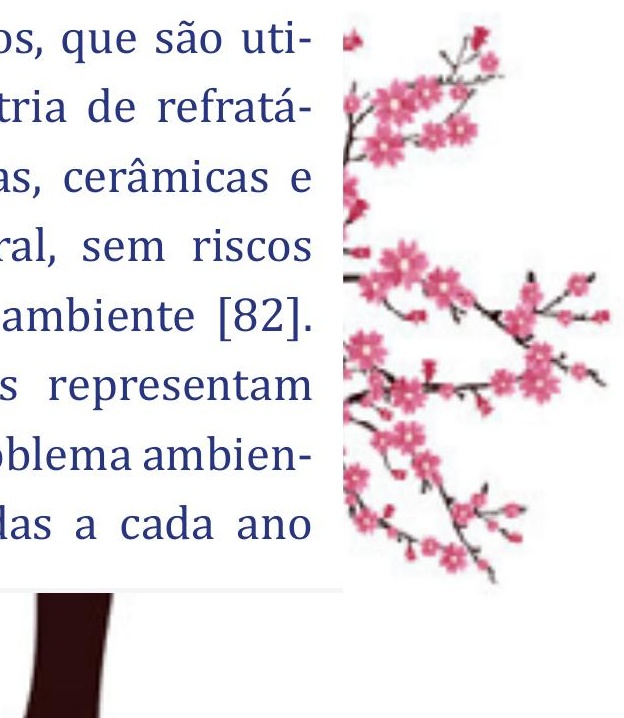


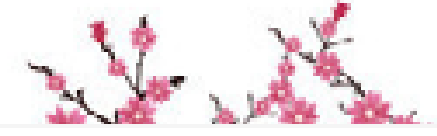

$\checkmark$ de pilhas secas (zinco-carbono)

e alcalinas (hidróxido de po- tos eletrônicos deve crescer contássio ou de sódio-zinco) [83]. sideravelmente nos países em desenvolvimento nos próximos

\section{Reciclagem de}

\section{Eletro - Eletrônico}

A rápida evolução tecno-

: lógica nos PC's faz com que uma grande quantidade de materiais, lixo eletrônico (os chamados e-waste ou e-lixo) sejam descartadosnomeioambiente, podendo assim contaminar o solo e água.

De acordo com o relatório do Programa das Nações Unidas para o Meio Ambiente (PNUMA), atualmente são gerados 40 milhões de toneladas de lixo eletrônico por ano no mundo, principalmente oriundos de países desenvolvidos. Só a União Europeia gera anualmente de 8,3 a 9,1 milhões de toneladas. 10 anos. Nestes países, a classe média está cada vez mais fortalecida e a estabilidade econômica leva ao aumento da compra de eletroeletrônicos [84]. A sustentabilidade no setor será garantida pelo reaproveitamento e reciclagem de materiais de informática como hard disks, drives e placas, entre outros. Outra ação importante é a de produtos com o "selo verde", ou seja, que os computadores estão livres de chumbo são econômicos no consumo de energia e seus componentes são totalmente recicláveis. 0 Centro de Computação Eletrônica (CCE) da USP, juntamente com a Mas-

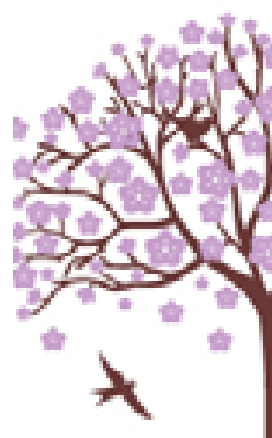


sachusetts Institute of Technology (MIT), dos Estados Unidos, é pioneiro nesse assunto [85]

Resíduos Hospitalares ou de Serviços de Saúde

Os resíduos hospitalares ou de serviços de saúde, incluem os resíduos infectantes (classe A) como culturas, vacinas vencidas, sangue e hemoderivados, tecidos, órgãos, perfurocortantes, animais contaminados, fluidos orgânicos; os resíduos especiais (classe B), rejeito radioativo, resíduos farmacêuticos e resíduos químicos; e os resíduos comuns (classe C), das áreas administrativas, das limpezas de jardins, conforme estabelecido na Norma NBR 12.808 - Resíduos de Serviços de Saúde [80]. Os resíduos sólidos dos serviços de saúde têm, em geral, três tipos de destino final: Grupo A - abrange os resíduos que apresentam riscos à saúde pública e ao meio ambiente devido à presença de agentes biológicos (resíduos hospitalares). 0 tratamento é realizado pelo Processo de Desativação Eletrotérmica (ETD), que consiste em triturar o material e depois aquecê-lo num processo semelhante ao do microondas doméstico; Grupo B - abrange drogas quimioterápicas, resíduos farmacêuticos e demais produtos considerados perigosos. 0 tratamento é realizado pelo processo de incineração, que reduz o peso e o volume do lixo por meio de combustão; Grupo C - abrange os resíduos radioativos ou contaminados com radionuclídeos que são provenientes de laboratórios de análises clínicas, serviços de

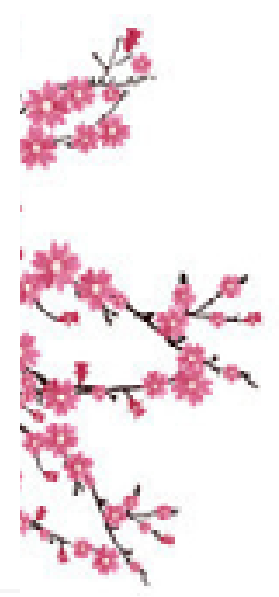




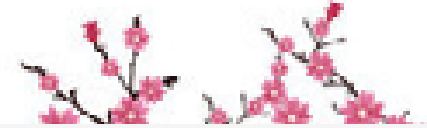

medicina nuclear e radioterapia. Recicla Lâmpadas que trabalha

E os animais mortos - animais com causa mortis desconhecida, sacrificados por eutanásia ou com doenças infectocontagiosas são incinerados [86].

\section{Reciclagem de}

: Lâmpadas Fluorescentes

Outro resíduo que deve ser tratado de forma especial são as lâmpadas fluorescentes que possuem em sua composição metais pesados, principalmente o mercúrio e necessitam de empresas especializadas nesse assunto. 0 Brasil possui um consumo médio anual de quase 100 milhões de lâmpadas fluorescentes em todo pais e apenas 6\% das lâmpadas descartadas passam por algum processo de reciclagem. Um exemplo de recicladora de lâmpadas é a empresa Tramppo com equipamento $100 \%$ desen-

volvido internamente, baseia-se em um processo de produção mais limpa, com reciclagem total da lâmpada, sem descartes em aterros, minimizando o volume do nosso lixo e principalmente evitando a contaminação dos solos e águas. Tecnologia aliada a sustentabilidade [87].

\section{Rejeitos Radioativos}

Os rejeitos radioativos, popularmente conhecidos como "lixo radioativo" ou "lixo atômico" são os mais diversos materiais resultantes da atividade humana que extrapolam os limites de presença de radionuclídeos estabelecidos pela Comissão Nacional de Energia Nuclear-CNEN, tem origem das instalações nucleares e instalações radioativas.
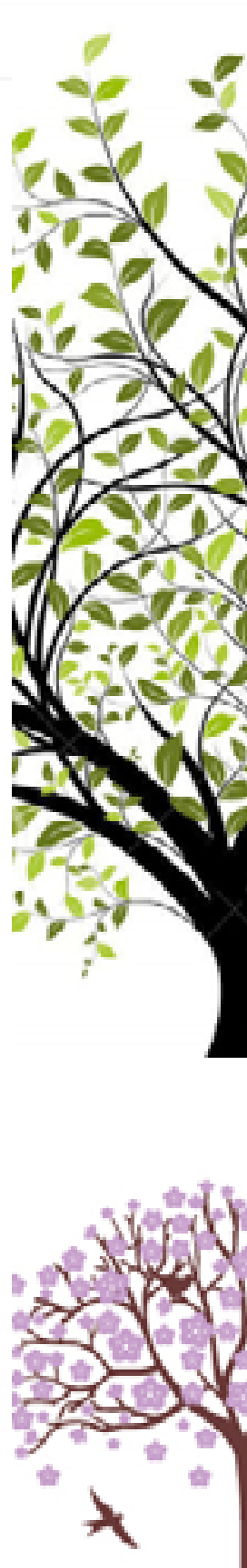
As instalações nucleares envolvem as instalações do ciclo de combustível, desde a mineração até o armazenamento final, já as instalações radioativas envolvem as clínicas, universidades, centros de pesquisa, indústrias [88]. Esses rejeitos radioativos devem ser acompanhados desdeseusurgimento até seu descarte ou armazenamento final, este processo é denominado gerenciamento de rejeitos, todos os recipientes contendo esses rejeitos devem ser identificados, datados e tem uma ficha de acompanhamento que deve ser arquivado para futuras consultas e fiscalizações. A Gerência de Rejeitos Radioativos é o conjunto de atividades administrativas e técnicas envolvidas na coleta, segregação, manuseio, tratamento, acondicionamento, transporte, ar- mazenamento, controle e deposição de rejeitos radioativos. Os rejeitos radioativos devem ser separados por estado físico: sólido, líquido e gasoso e são classificados em rejeitos de baixa, média e alta atividade. Eles devem ser segregados, ou seja, separados pelo estado físico (sólido, líquido e gasoso), pela meia-vida curta ou longa T1/2 > 60 dias, compactáveis e não compactáveis putrescíveis ou patogênicos, se for o caso e outras características perigosas (explosividade, combustibilidade, inflamabilida-de, piroforicidade, corrosividade e toxidade química) [89]. 0 descarte desses rejeitos radioativos só poderá ser feito após decaimento em depósito apropriado para este fim, e até que tenham atingido os limites de descartes pela norma CNEN 6.05 [90].

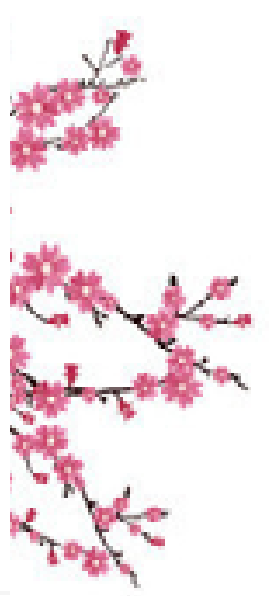

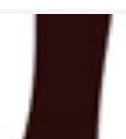




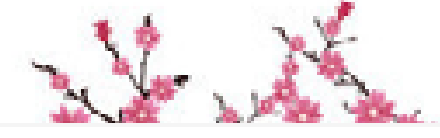

Todo material não re- é totalmente coberta e poderá - ciclável, ou seja, aquele que ser utilizada como área de lazer, não pode ser reutilizado após depois que o nível de contamitransformação química ou fí- nação for praticamente zerado. sica é destinado a aterros sa- A formação de gás metano devinitários e os orgânicos podem ir para compostagem [90].

\section{: Aterro Sanitário}

Os aterros sanitários são grandes áreas preparadas tecnicamente para receber os resíduos domiciliar, o de limpeza pública de ruas e o de indústrias, desde que não sejam tóxicos e devidamente autorizados pelos órgãos ambientais. Os resíduos hospitalares e de saúde são destinados a tratamento apropriado. Estas áreas contam com garantias de proteção ao meio ambiente, evitando a contaminação do lençol freático. Após o esgotamento dos aterros, a área do a fermentação dos produtos orgânicos nos aterros sanitários é inevitável, com a finalidade do aproveitamento do biogás como fonte de energia de baixo custo econômico, alguns empresas como a Heleno \& Fonseca, em parceria com a Arcadis Logos Engenharia S.A. e a Van der Wiel Stortgas B.V., constitui a Biogás - Energia Ambiental S.A., se juntaram para comercializar o biogás gerado pelo aterro sanitário bandeirantes em São Paulo, visto que o mesmo apresenta altas concentrações de metano, com valores próximos a 55\% ideais para utilização [91]. Quando a coleta seletiva não

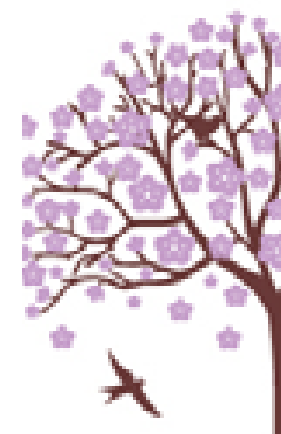


é eficientes muitos materiais biológicos como enzimas [80]. que poderiam ser destina- A biorremediação pode ser usados a reciclagem acabam indo da como tratamento de resíduos para os aterros sanitários. sólidos seja em áreas controladas como os aterros, sejam em

\section{Biorremediação}

A compostagem é um exemplo bastante conhecido de tratamento biológico e, portanto, de biorremediação, utilizado para o tratamento de resíduos sólidos orgânicos. Defini-se biorremediação como um conjunto de tecnologias que utilizam processos biológicos aplicados à recuperação ou remediação de áreas contaminadas, ou no tratamento de compostos orgânicos voláteis tóxicos ou efluentes contendo resíduos tóxicos que devam ser eliminados antes da descarga no ambiente. Para isto, em geral, utilizam-se microorganismos, plantas ou produtos áreas degradadas anteriormente, aterros mal administrados, aterros antigos, áreas contaminadas por pesticidas, explosivos, óleo e os mais diversos compostos, advindos das mais diferentes situações: despejos, acidentes, antigos aterros.

\section{Compostagem}

A compostagem é um processo biológico em que os microrganismos transformam a matéria orgânica, como estrume, folhas, papel e restos de comida, num material semelhante ao solo, a que se chama composto, e que pode ser utilizado como
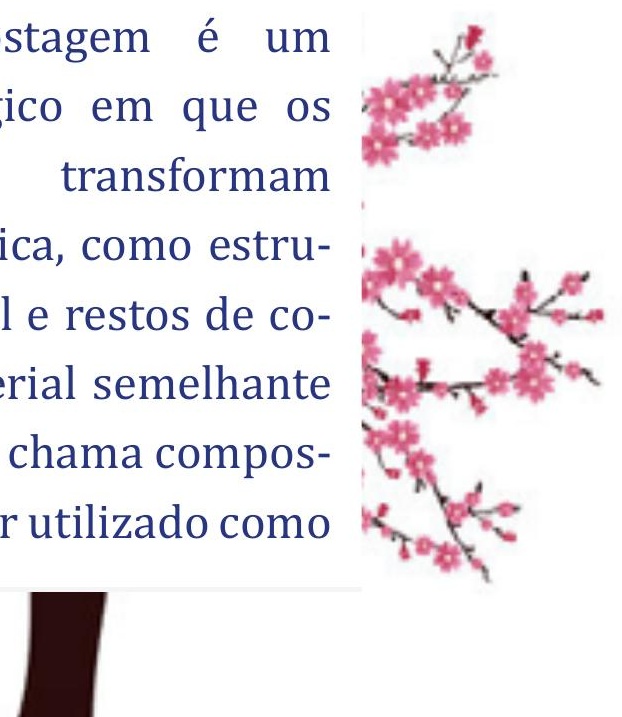


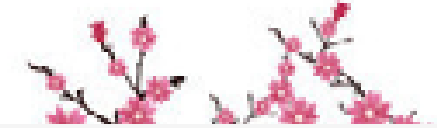

adubo. É uma estrutura própria

\ para o depósito e processamento do material orgânico [79].

set:

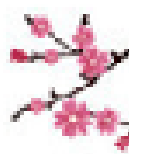

90
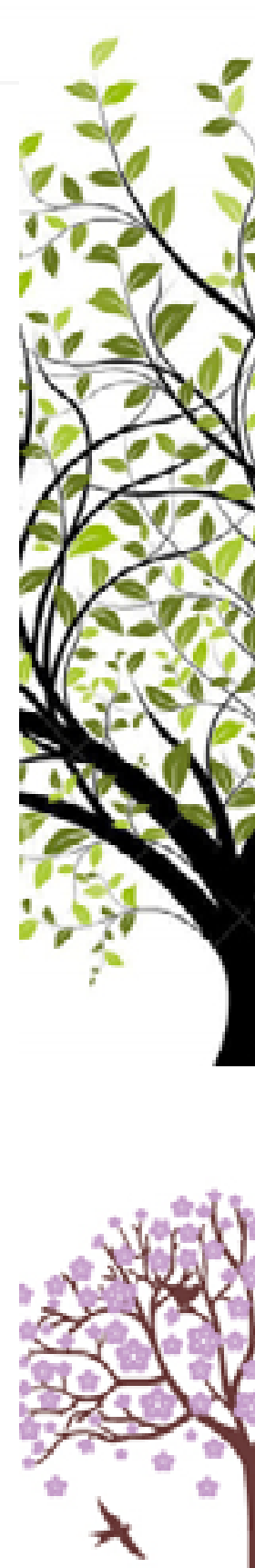


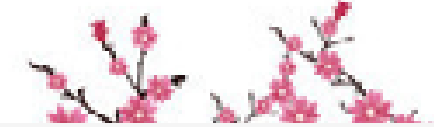

$-4$

\section{SUSTENTABILIDADE}

O aumento da ocupação humana no planeta tem causado sérios danos ao meio ambiente e, entre as atividades que apresentam mais fatores impactantes está a agricultura [92]. A agricultura moderna originou-se nos séculos XVIII e XIX * em grande parte da Europa e divide-se em duas fases, a primeira e a segunda revolução agrícola contemporânea [93]. Possui características que se aproximam de uma indústria extrativa, o que tende a torná-la não sustentável [94]. A primeira revolução agrícola contemporânea caracterizada pelo abandono do pousio (é nome que se dá ao descanso ou repouso proporcionado às terras cultiváveis) e pela introdução de sistemas rotacionais com leguminosas ou tubérculos, com isso intensificou-se a utilização da terra, aumentando a produção agrícola, com o objetivo de eliminar a escassez de alimentos de períodos anteriores. A chamada segunda revolução agrícola contemporânea ocorrida no final do século XIX e inicio do século XX na Europa e EUA foi marcada por avanços científicos e tecnológicos com a introdução de fertilizantes químicos, o que levou ao abandono da adubação verde e do esterco na fertilização das lavouras, motores de combustão, melhoramento genético de plantas e redução da rotatividade

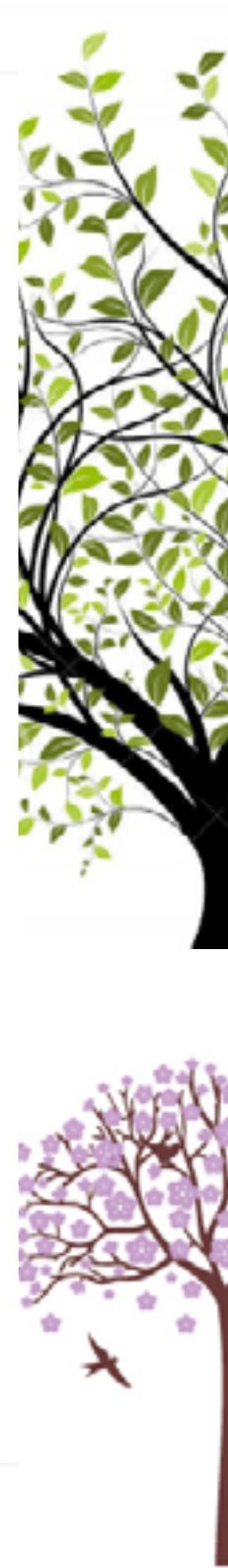


de culturas e finalmente a absorção de algumas etapas agrícolas pelas indústrias (primeiros passos para a agroindústria). Com a intensificação da produção de insumos agrícolas a partir da primeira guerra mundial utilizando cada vez mais recursos tecnológicos e menos recursos locais, a indústria passa a manipular grande parte da produção agrícola. Tudo isso culminou na chamada revolução verde no final da década de 1960 que visava à monocultura e a produção estável de alimentos, lutando contra a deficiência de alimentos pela aplicação massiva de inovações tecnológicas no campo, como motomecanização, fertilizantes químicos, pesticidas e irrigação e, muitos países investiam alto nessas tecnologias. Nos anos 70 iniciam-se movi- mentos de oposição e crítica a esse sistema, devido às conseqüências do modelo tais como: erosão do solo, contaminação da água por agrotóxicos, eutrofização da água pelo uso de adubos químicos, aumento do numero de pragas e doenças, destruição de habitats naturais, erosão genética e aumento da instabilidade econômica e social nas comunidades de agricultores familiares.

Via-se a necessidade de promover mudanças no modelo utilizado, já que não só estava-se degradando o meio ambiente como exterminando espécies animais e vegetais e colocando a própria espécie humana em risco, e passa-se a pensar em sustentabilidade

[93].

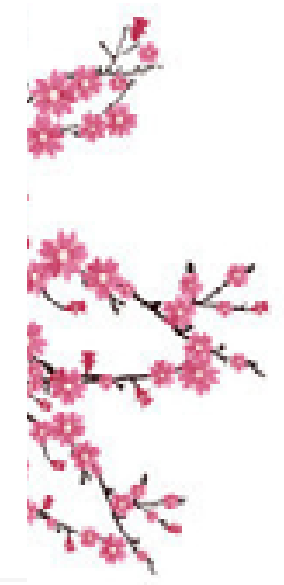




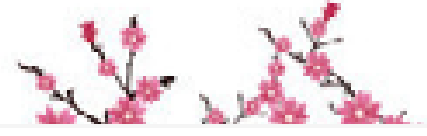

Agroindústria

A agroindústria compreende a atividade econômica de industrialização ou beneficiamento de produtos agropecuários, agregando valor às matérias primas. Elas vão das mais artesanais as mais sofisticadas

em termos tecnológicos. A mais importante é a alimentar, onde estão inseridas frutas, legumes, hortaliças, grãos, oleaginosas, carne, leite e pescados. Nos sistemas agrícolas modernos estão incluídos os agronegócios, geralmente monoculturas, como a soja e o café, além de reflorestamentos e pastagens, altamente dependentes de técnicas modernas como sementes melhoradas geneticamente, equipamentos agrícolas, fertilizantes químicos e agrotóxicos. São culturas extensivas com grande risco ambiental devido as suas características de uso exaustivo do solo, que pode causar erosão, compactação, redução das águas e alta utilização de insumos externos ao meio. Algumas medidas podem ser adotadas para a redução desses impactos, tais como cobertura do solo, cultivo integrado com a rotação de culturas, formação de faixas contra a erosão, redução da utilização de máquinas pesadas reduzindo a pressão sobre o solo, reflorestamento com espécies nativas, tratamento correto do solo, seleção de sementes resistentes, nutrição das plantas por adubação orgânica entre outras medidas [95]. Um dos temas cruciais em relação a agroindústria relaciona-se ao estudo da localização de suas instalações. Sua principal preo-

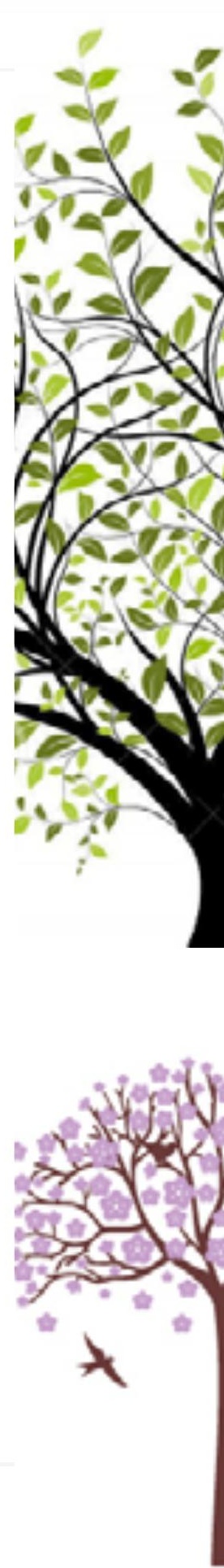




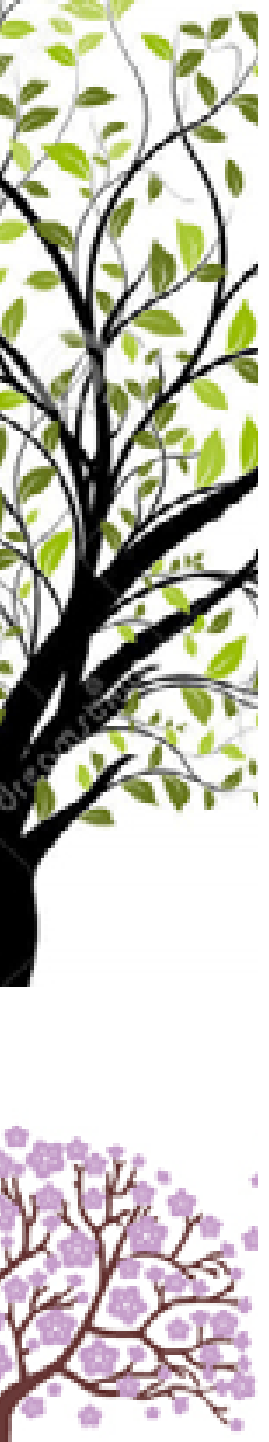

cupação tem como foco a água,

xas e, a depender da matériapois os principais impactos cau-prima utilizada, esses resíduos sados por este tipo de atividade estão relacionados ao seu elevado consumo. A sua utilização se faz presente em várias etapas do processo como: matéria-prima, processamento, limpeza, resfriamento, segurança, geração de vapor. Contudo, o lançamento de efluentes e a disposição dos resíduos sólidos também geram igual atenção, pois os mesmos podem causar a contaminação das águas, da atmosfera, além de promover alterações no solo. A geração de resíduos depende fundamentalmente das matérias-primas e dos processos de produção utilizados. Esses efluentes possuem alto nível de demanda bioquímica e química de oxigênio, sólidos em suspensão e dissolvidos, óleos e gra-

poderão apresentar colibacilos. Resíduos de agrotóxicos, óleos complexos, compostos alcalinos e outras substâncias orgânicas também poderão surgir. Em relação à poluição atmosférica, essa poderá ser gerada pela emissão de poeira e materiais particulados, materiais pulverizados, dióxido de enxofre, óxidos nitrosos, hidrocarbonetos e outros compostos orgânicos. 0 armazenamento incorreto das matérias primas e a eliminação ou disposição de resíduos sólidos podem contaminar o solo, as águas superficiais e subterrâneas e degradar a vegetação. Os principais impactos ambientais que podem ser gerados pela agroindústria, além dos já citados são a contaminação das

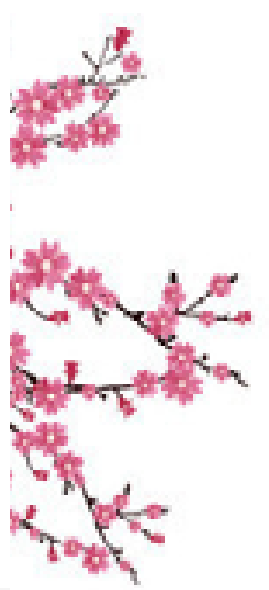

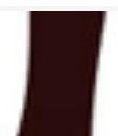




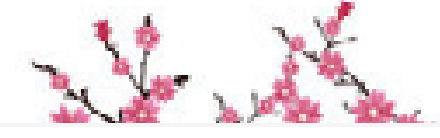

de efluentes sem tratamento ou

s.t. com tratamento parcial; incô$=$

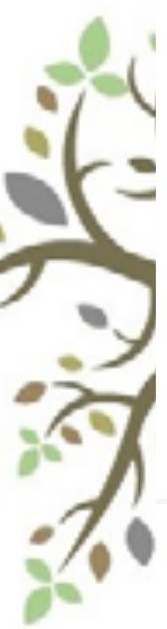
modos à vizinhança pela geração de odores desagradáveis, devido a deterioração de resíduos e dos efluentes; poluição do ar; prolife-

águas superficiais e subterrâneas em função do lançamento ração de vetores de doença [96]. Abaixo serão apresentadas, de forma resumida, algumasatividades do setor agroindustrial, destacando-se os principais impactos negativos de cada atividade:

- Processamento de cereais: emissão de pós que poderão provocar a contaminação da água e do solo; geração de ruídos que provocam incômodo no local de trabalho e em seu entorno; - Produção de chá e café: as substâncias formadas durante a fermentação podem ser acumuladas no solo, causando prejuízos à microfauna e microflora; a lavagem após a fermentação produz águas residuárias biologicamente contaminantes; - Processamento do leite: águas de processo, contaminadas por componentes do leite; resíduos de enxágüe de perdas e de purificação, contaminados por soluções alcalinas, ácidas e desinfetantes; resíduos sanitários; - Processamento de frutas e hortaliças: a água residual utilizada para a lavagem da matéria-prima poderá conter detergentes, agrotóxicos e material corrosivo; a presença de sucos e restos de frutas poderão se fazer presentes também na água, ocasionando o mal cheiro; - $\quad$ Produção de cana-de-açúcar: podem ser gerados efluentes hídricos e atmosféricos, bem como resíduos sólidos, os quais

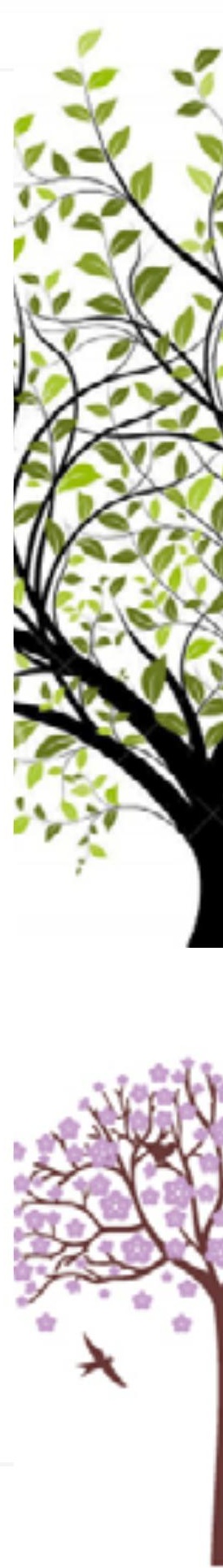


poderão contaminar as águas superficiais, subterrâneas e o solo. - Produção do álcool: as águas residuárias de uma unidade de produção de álcool são altamente poluidoras, particularmente pela vinhaça/ vinhoto. Para cada litro de álcool produzido, são produzidas 12 a 15 litros de vinhoto;

Matadouros de pequeno porte: todo o processo de lavagem e retirada de vísceras, pêlos e outras partes do animal, consome uma grande quantidade de água e resulta em águas residuárias com a presença de sangue, pêlos, graxas, fezes. Estima-se que para cada bovino abatido são gerados de 600 a 800 litros de água residual, suíno 300 a 500 litros e ovinos de 200 a 300 litros; toda essa água resultante do processo pode- rá vir a contaminar o solo, das águas superficiais e subterrâneas, além de gerar odor desagradável oriundo da matéria orgânica em decomposição [97]. 0 atual modelo de agroindústria está muito longe de ser sustentável. Se a agricultura minimizar ou extinguir o uso de fertilizantes, utilizando técnicas como o cultivo direto, por exemplo, os agrotóxicos com o cultivo de orgânicos, investir em estudos e pesquisas onde o reaproveitamento do material que antes era descartado seja uma prioridade, minimizar o uso da água e garantir que ao ser devolvido ao meio ambiente ela se encontre em condições muito próximas àquelas apresentadas no início de todo o processo, além dos cuidados com o solo citados, a agroindústria

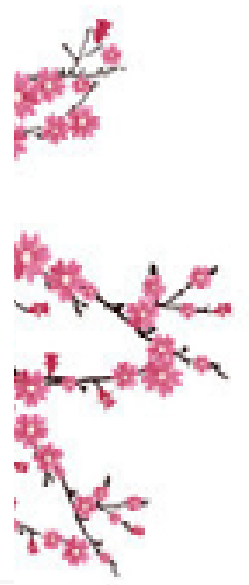




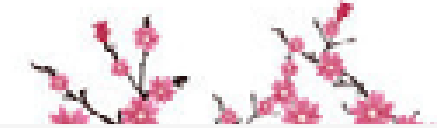

deixará de ser um grande agen-

sa capacidade futura de praticar te degradador do meio ambienagricultura com sucesso [93]. te e passará a assumir um papel De uma forma geral, o conceito de suma importância em matéria de sustentabilidade [98].

\section{Agricultura Sustentável}

A agricultura sustentável

: pode ser definida como uma agricultura ecologicamente equilibrada, com a manutenção dos recursos naturais e mínimos impactos ao meio ambiente; economicamente viável, com o retorno adequado aos produtores e a otimização da produção além da satisfação das necessidades humanas de alimento e renda; justa socialmente, atendendo às demandas sociais das famílias e das comunidades rurais $[93,99]$. Seus processos consistem em atividades que produzam culturas que não comprometam nosde agricultura sustentável envolve tanto aspectos ambientais quanto socioeconômicos. Como alternativa a agricultura tradicional que é a prática mais comum nos dias atuais e é considerada de alto impacto, pois utiliza técnicas como a aragem, tradagem, subsolagem e causa a erosão, o baixo teor de matéria orgânica do solo, alta lixiviação de nutrientes, e desequilíbrio biológico do solo, podemos citar o plantio direto e a agricultura orgânica, além da utilização da rotação de culturas, menos impactante que a monocultura [92].

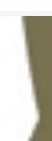




\section{Sistema de Plantio}

\section{Direto e Agricultura}

Orgânica

0 sistema de plantio direto tem sido amplamente utilizado nos dias de hoje já que causa menos impactos que a agricultura tradicional por utilizar princípios conservacionistas de preservação e ciclagem de nutrientes. Uma das bases do sistema é revolver o solo o mínimo possível, já que quando revolvemos o solo, a matéria orgânica é rapidamente decomposta. No plantio direto a semente é semeada direto no solo, sem aração ou gradagem, sendo feito apenas um pequeno sulco para comportar a semente. Após a colheita os restos da cultura são roçados, permanecendo no solo o que reduz muito a erosão, bem como a utilização da rotação de culturas. O sistema conserva a matéria orgânica do solo, retêm nutrientes, aumentando a quantidade de microorganismos benéficos no solo e desta forma armazena uma maior quantidade de água reduzindo a erosão e a lixiviação. 0 plantio direto assemelha-se à condição de floresta onde não há o movimento de solo e existe uma grande quantidade de matéria orgânica. Isso torna esta prática mais sustentável e mais produtiva que a técnica tradicional, sendo a mais recomendada atualmente para os grandes plantios. Como limitações podem ser citadas: algumas doenças e insetos que se favorecem nesse processo e falta de conhecimento técnico $[92,101]$. A agricultura orgânica ainda tem seu uso restrito e baseia-se na ausência de pesticidas utilizan-
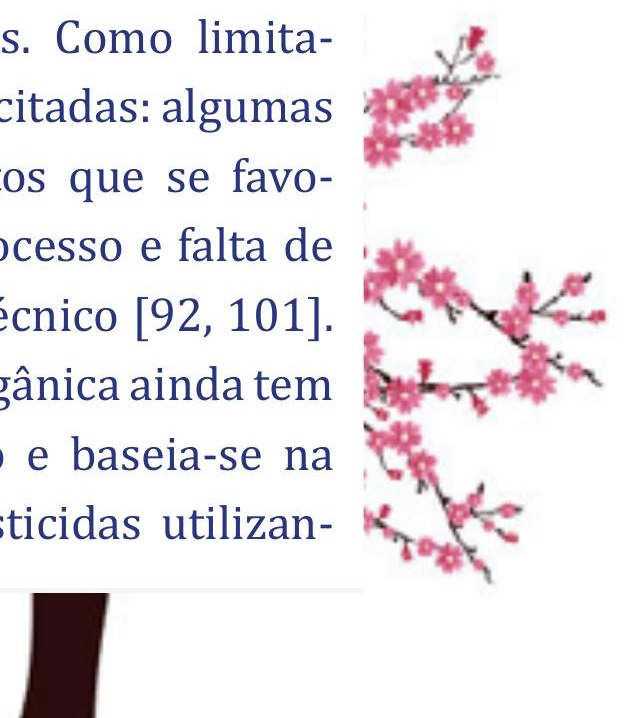


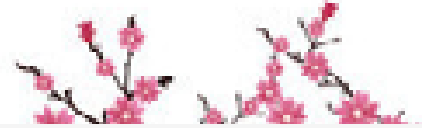

$m$

mo sendo sustentável do ponto

de vista ecológico, não é do ponto de vista econômico e social devida a sua baixa produtividade já que é limitada a pequenas produções e possui um alto cus-

: to, além das altas infestações de ervas daninhas e pragas [92]. Além da agricultura alternativa, que tem um papel importante no processo de desenvolvimento da agricultura sustentável, é necessário levar em consideração a complexidade ambiental, econômica e social de cada sistema agrícola, tendo como referência as condições locais [93]. A grande pressão sobre o ambiente vindo da agricultura indica a necessidade de um novo paradigma cientifico e tecnológico nesta área, onde as inovações compreendam além da visão utilitária da agricultura outras dimensões. A busca pela sustentabilidade na agricultura deve considerar não somente os aspectos ambientais ou somente os aspectos socioeconômicos, mas o equilíbrio entre elas, buscando como resultado uma agricultura altamente produtiva, de qualidade e custos baixos, equilibrada com o meio ambiente $[92,94]$.

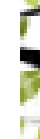
i

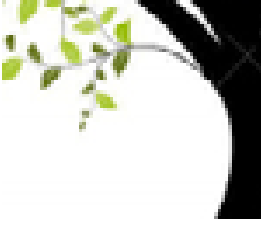

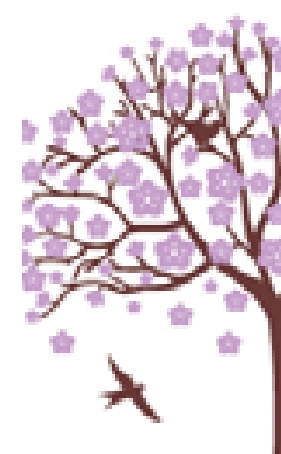




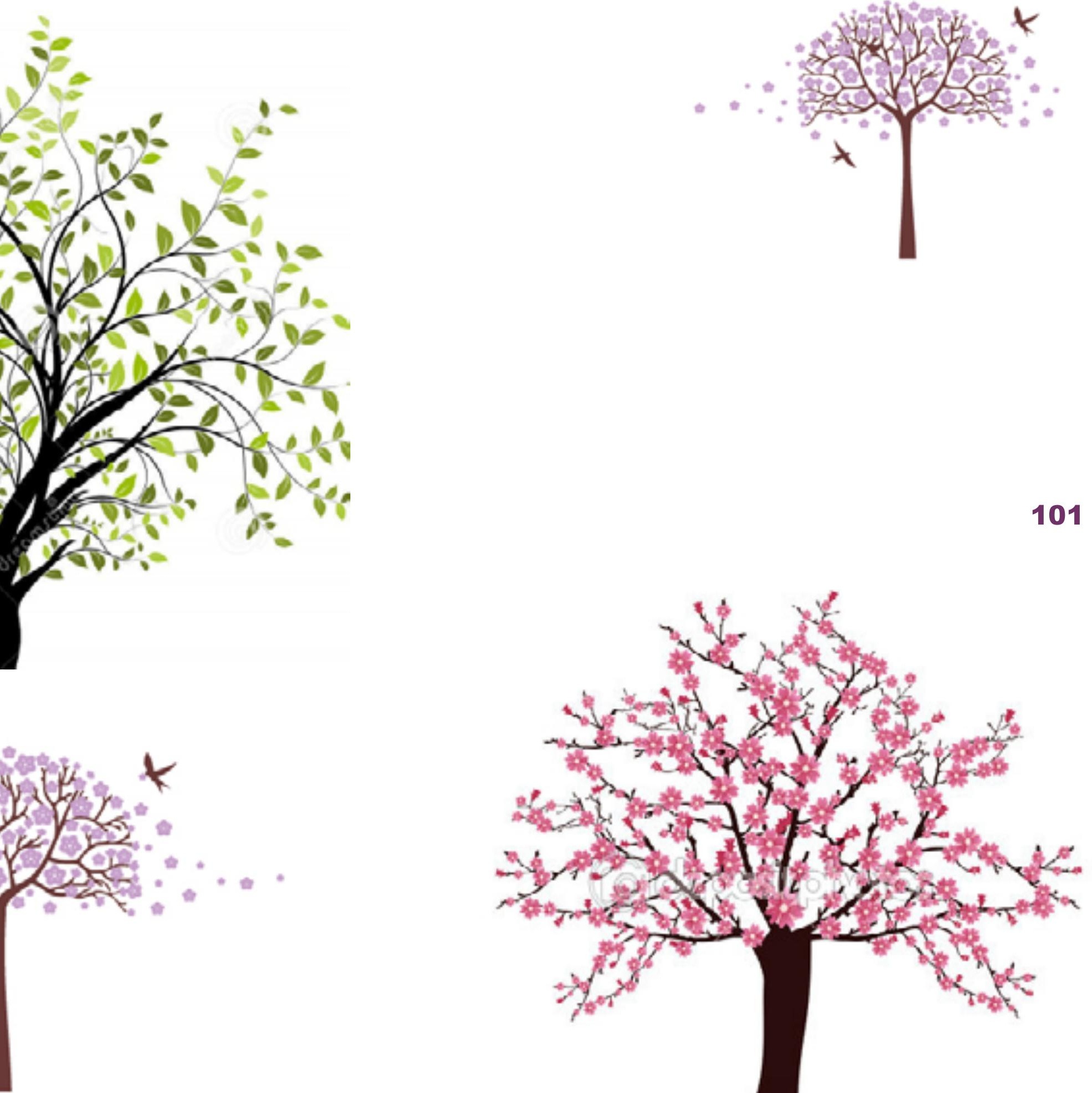




\section{SUSTENTABILIDADE}

\section{EMPRESARIAL}

É fundamental a compreensao sobre o conceito de desenvolvimento sustentável e sustentailidade. Quando se menciona desenvolvimento sustentável, uma vez que muitos utilizam o termo para designar a expectativa de que o país entre numa fase de crescimento que se mantenha ao longo do tempo, faz com que tal forma de

desenvolvimento pressuponha a expansão econômica permanente, gerando melhoria nos indicadores sociais, além da preservação ambiental. Sustentabilidade é a capacidade de se auto sustentar, de se auto manter. Uma atividade sustentável qualquer é aquela que pode ser mantida por um longo período de tempo, de forma a não se esgotar nunca, apesar dos imprevistos que podem vir a ocorrer durante este período. Pode-se ampliar o conceito de sustentabilidade, em se tratando de uma sociedade sustentável, que não coloca em risco os recursos naturais como o ar, a água, o solo e a vida vegetal e animal dos quais a vida (da sociedade) depende [101, 102]. Apesar de apresentarem similaridades torna-se comum relacionar desenvolvimento sustentável a políticas públicas e sustentabilidade as demais ações. A partir desta explanação o termo a ser utilizado será sustentabilidade, pois relaciona o termo com as empresas e organizações. Na área empresarial a preocupação com a sustentabilidade tem se generalizado, e um grupo mais envolvido

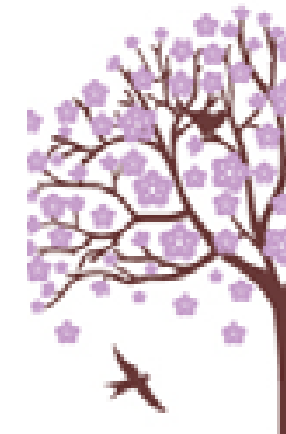


com esta inquietação criou uma entidade voltada a sustentabilidade empresarial, ligada ao movimento internacional de empresários com este foco [101].

\section{Sustentabilidade}

\section{Empresarial ou Industrial}

Existe uma variedade de definições concernente a este conceito de sustentabilidade empresarial. Em cada uma delas percebe-se a necessidade de introduzir elementos e contextos de modo a torná-las mais completa. Desenvolvimento sustentável tampouco implica transgressão alguma ao principio de soberania. Considera-se que a consecução do desenvolvimento sustentável envolve cooperação dentro das fronteiras nacionais e por meio daquelas. Implica progresso na direção da aquida- de nacional e internacional, inclusive assistência aos países em desenvolvimento de acordo com seus planos de desenvolvimento, prioridade e objetivos nacionais [103]. Implica também a existência de meio econômico internacional propício que resulte ao crescimento e no desenvolvimento. Estes são elementos da maior relevância para a gestão sadia do meio ambiente. Desenvolvimento sustentável implica ainda a manutenção, o uso racional e valorização da base dos recursos naturais que sustenta a recuperação dos ecossistemas e crescimento econômico. Desenvolvimento sustentável implica, por fim, a incorporação de critérios e considerações ambientais na definição de políticas e de planejamento de desenvolvimento e não represente uma
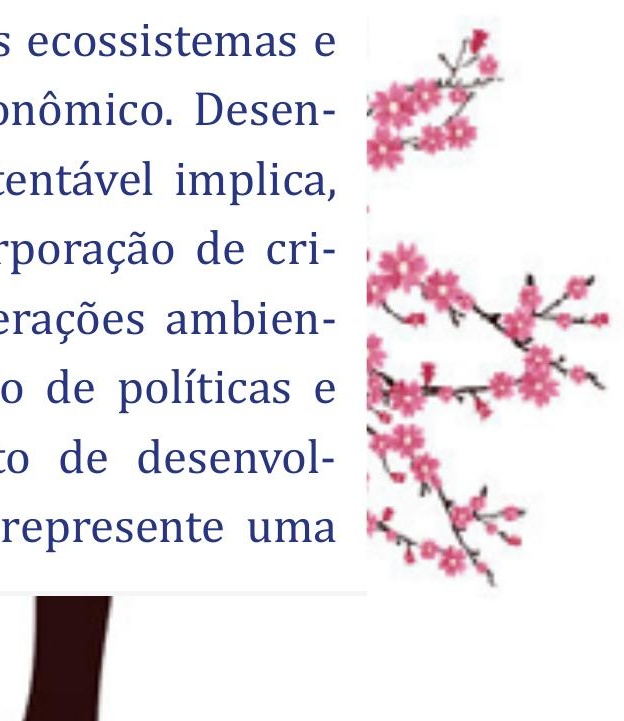


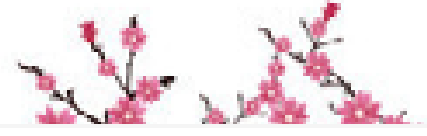

$=$

para o desenvolvimento. 0 conselho de administração esta inteiramente consciente de que os próprios países são e devem ser os principais atores na reorientação de seu desenvolvimento : de forma a torná-lo sustentável. o desenvolvimento sustentável e ambientalista sadio é de grande importância para todos os países, industrializados e em desenvolvimento. Os países industrializados possuem os recursos necessários para fazer os ajustes requeridos, algumas das atividades econômicas efetivamente têm impacto substancial no meio ambiente, não apenas no âmbito nacional, mas alem se suas fronteiras. Mesmo no caso dos países em desenvolvimento, a maior parte dos recursos para o desenvolvimento provém deles mesmos. Para estes, muito embora a manutenção da base de recursos naturais para as futuras gerações seja de grande relevância, as necessidades da geração atual são de importância crítica. Ações induzidas pela pobreza e pela necessidade de sobrevivência deterioram a base de recursos e assim geram mais pobreza. Em todos os países, questões de desenvolvimento e meio ambiente estão entrelaçadas em uma mútua interação. "Hoje, novas questões ambientais desafiam a comunidade internacional, enquanto as velhas questões se mantêm e até adquirem maior magnitude" [104]. Empresas ou indústrias contemporâneas querem sejam elas pequena, média ou grande é imprescindível verificar uma vasta

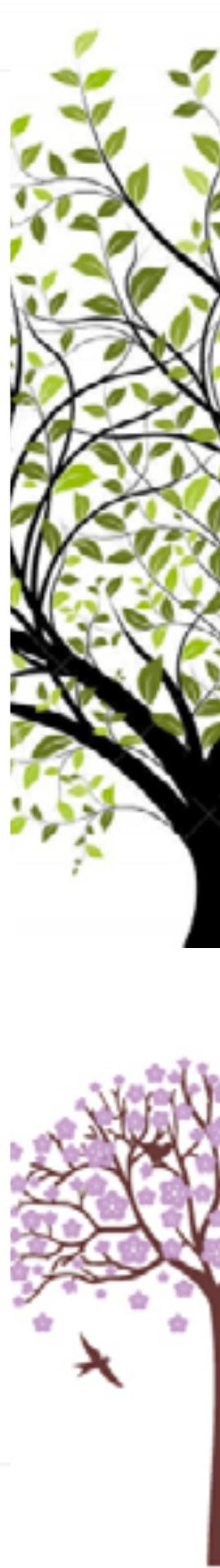


gama de situações ambientais presentes atualmente. Entre essas situações não se pode negar a destruição visível na camada de ozônio, as alterações no ecossistema Vê-se, por exemplo, o que acontece hoje em África, mas concretamente no Quênia com a montanha do Kilimanjaro (o derretimento do gelo). Tudo isso nada proveitoso para um desenvolvimento sustentável da humanidade tem crescido nos últimos anos levando as populações dos trópicos em particular dos países subdesenvolvidos, a situações nada desejáveis. De igual modo, a poluição dos rios o desmatamento, a extração de matéria prima pelas mineradoras e a pesca predatória, faz com que a situação de risco dos sistemas alimentícios, a perda das fontes de água, bosques e espécies se tornem uma verdade que se deve levar em consideração quando se fala em sustentabilidade empresarial ou industrial. Sendo as mais vulneráveis a essas mudanças as regiões do trópico já que é ela que tem a maior diversidade do planeta. Adaptação das empresas ou indústrias diante de situações indesejadas deve ser vista por todos os empresários com a oportunidade para contribuir para o desenvolvimento sustentável da sua comunidade região ou país. As recentes mudanças políticas e econômicas obrigam a pensar que a empresa e a indústria são os motores catalisadores do desenvolvimento sustentável, a base para avançar rumo ao futuro promissor. Elas têm agora a missão de fazer a sua parte para a construção da nova sociedade.

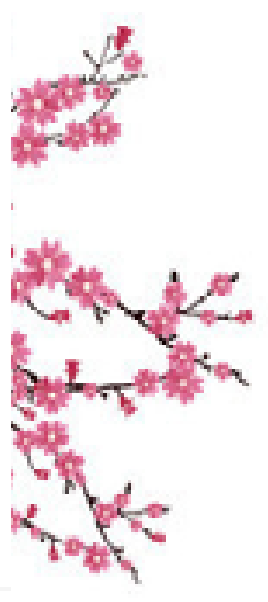




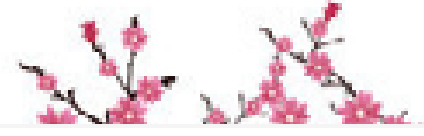

O conceito de desenvolvimento

$\bullet$

Capital

conjunto de recursos modústrias está fundamentada nos netário à disposição [105]. seguintes pontos: todas as regiões do planeta tenham garantia de alimento; os ecosostemas sejam produtivos e protegidos e que as condições climáticas * sejam estáveis e seguras; as atividades humanas não comprometam as futuras gerações visando sembre o seu bem estar. Paraque este bem feito sejaalcançado, o mundo deve contar com: - Capital humano - refere-se à capacidade de pensamento critico e analítico, assim como criatividade e iniciativas para empreender novas empresas ou indústrias; Capital ecológico - são os recursosqueoindividuotemàsua disposição para a geração do seu desenvolvimento na sociedade; Entende-se hoje que qualquer instituição comercial ou industrial deveria focalizar-se em buscar a realização dos objetivos econômica, social, e sobre tudo ambiental para a contribuição de um desenvolvimento sustentável do meio em que vive. No que tange ao objetivo ambiental as empresas ou indústrias devem conduzir a sociedade à promoção do desenvolvimento da biodiversidade e a manutenção dos ecossistemas. A orientação de qualquer empresa ou indústria, pela visão econômica deve ser o crescimento, a eficiência e a inovação. Em qualquer sistema econômico, empresa ou indústria deve contribuir para o acesso justo e igualitário à forma-

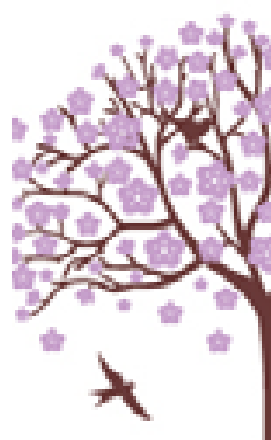


ção e ao conhecimento. Isso se nômico, onde o aspecto social torna cada vez mais um direito recebe maior ênfase, tanto no reivindicado pelos povos [104]. se refere às praticas como no que se refere aos motivos, suIniciativas Sobre Sustentabilidade

\section{Empresarial no Brasil}

0 modelo de crescimengerindo que, mais que um mero modismo, o desenvolvimento sustentável tem sido visto pelo mercado como elemento fundato praticado ao longo da era industrial, no qual as organizações ocupam-se apenas em extrair, transformar, comercializar e descartar os recursos naturais utilizados, já não é mais viável, tendo em vista que esses recursos estão ameaçados a escassez. $\mathrm{Na}$ compreensão do conceito de desenvolvimento sustentável adotado pelas organizações por meio da análise do discurso empresarial percebe-se que o desenvolvimento sustentável está pautado nos seus três pilares: social, ambiental, e ecomental para a sobrevivência das organizaçõesalongo prazo [106]. A crescente exposição na mídia dos danos que as organizações vêm causando ao meio ambiente fez surgir a preocupação de que este não ofereça mais condições adequadas para que as empresas operem em um futuro próximo. Essa exposição, aliada à melhoria do nível educacional da sociedade e a velocidade da disseminação, provocou o surgimento de um novo mercado consumidor, que agora, mais informado e esclarecido, tornou-
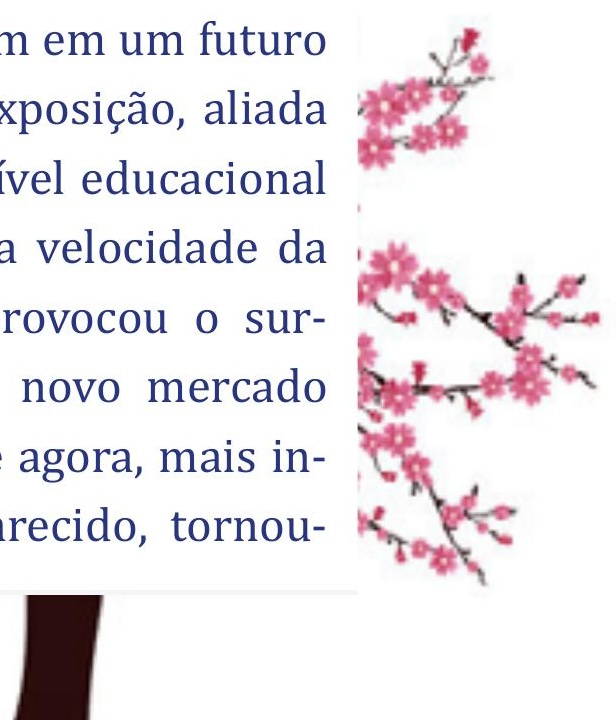


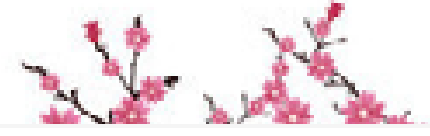

-se mais exigente, pressionando - as empresas a adotar um modelo de atuação mais responsável. É assim que o desenvolvimento sustentável está presente no Brasil desde 1913, quando se criou o primeiro parque nacional para a preservação do meio : ambiente, o parque Nacional de Itatiaia, situado na divisa do estado do rio de Janeiro com Minas Gerais. Em 1915, outros dois importantes parques foram criados: Cataratas do Iguaçu, no rio Paraná e Serra dos Órgãos, no Rio de Janeiro [107].

A crescente aparição na mídia dos assuntos relacionados ao meio ambiente no Brasil, pais de riqueza ambiental indiscutível, chamou a atenção de cientistas, jornalistas e políticos, que iniciaram fóruns de discussões com intuito de sen-

sibilizar a comunidade para o processo acelerado de destruição do meio ambiente [108]. Do resultado dos fóruns, em 1958, nasce no Rio de Janeiro a Fundação Brasileira para a Conservação da Natureza considerada a primeira organização ambiental que conseguiu criar e manter uma presença nacional. Essa fundação alcançou vários intentos, pois contava com associados capazes de influir diretamente em medidas governamental de proteçào da natureza. Em 1997, cinco anos após a Rio 92, foi criado no Brasil o Conselho Empresarial Brasileiro para o Desenvolvimento Sustentável (CEBDS), entidade sem fins lucrativos que integra a rede de conselhos vinculados ao World Business Council for Suatainnable Development (WBCSD). 0

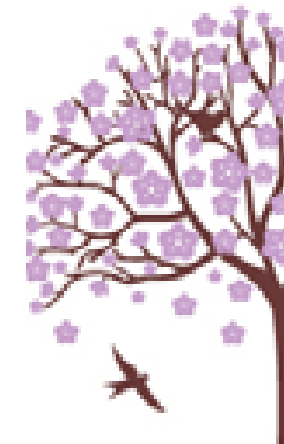


CEBDS agrupa 56 grupos empresarias mais expressivo no Brasil, representando cerca de 450 unidades produtivas.Sendo um conselho que atua juntamente com empresas, o CEBDS possui um importante papel na defesa do desenvolvimento sustentável no país, provendo seminários e reuniões, praticas de debates, trabalho em parceria com organizações não governamentais e instituições acadêmicas [104, 108]. Algumas delas estão experimentando ações em direção ao desenvolvimento sustentável, por entenderem que a pratica da sustentabilidade, no sentido de várias áreas de influência dos países desenvolvidos, poderá proporcionar sua sobrevivência. Propõe-se que todas as áreas do pensamento e da ação humana devam se comprometer com o combate aos desequilíbrios socioambiental apesar de o processo de mudança que consiste em divulgar o conceito da sustentabilidade esteja em construção. É indispensável que as empresas discutam de forma confiável seu planejamento estratégico a assuntos ligado ao desenvolvimento sustentável[109]. Ainda segundo para que as organizações efetivamente obtenham sucesso em suas estratégias de desenvolvimento sustentável, é fundamental que elas considerem o interesse de seus diversos públicos estrangeiros, pois possuem obrigações não só com elas mesmas, mas também com todos os seus grupos de interesse, com fornecedores, clientes, colaboradores, entre outros. Assim sendo os desafios que as organizações passam a
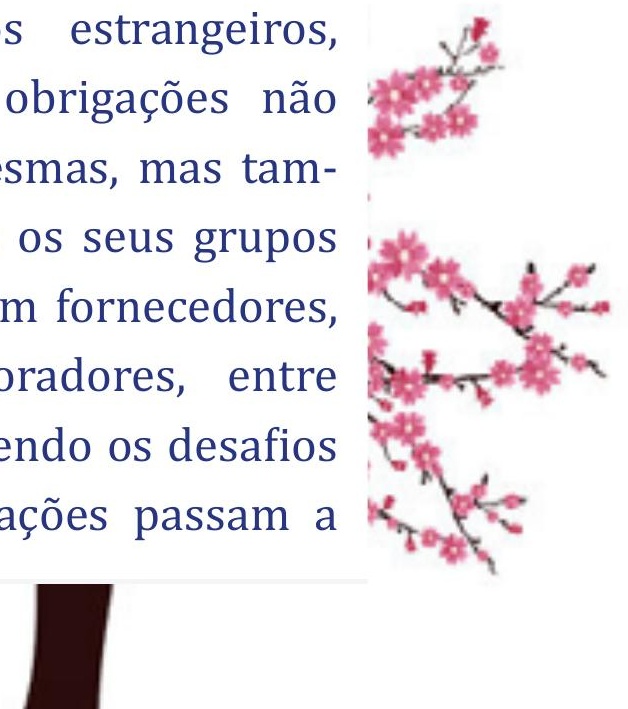


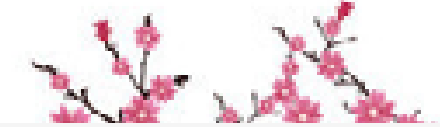

ofp Sendo

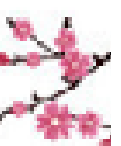
que a visão organizacional de sustentabilidade sustenta-se em quatro pilares: - Razões físicas, onde en-

* contramos os recursos naturais e o meio ambiente; - Razões sociais, que englobam ações efetivas de organização na sociedade, alem do simples cumprimento de leis ou criação de empregos;

- Razões éticas, que incluem a individualidade e os valores pessoas no trabalho, alem de contribuir para a distribuição de oportunidades para a sociedade; tivas viu-se surgir o conceito ecoeficiência. A ecoeficiência consiste em aproveitar da melhor forma o uso da matéria - prima e o da energia para aumentar os benefícios econômicos e ecológicos com o objetivo de reduzir o impacto no meio ambiente. Ela vem para criar oportunidades que impulsionem a rentabilidade e o desenvolvimento sustentável. Dentre alguns benefícios destacam-se: - Uso de combustíveis alternativosereutilizaçãoderesíduos; - Aproveitamento damelhor maneirados recursos renováveis; - Aumento do tempo de vida dos produtos; Diminuição consumo de - Crescimento

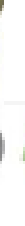

- Razoes de negócios, resultados da combinação dos três pilares anteriores [110]. Com todas essas inicia-

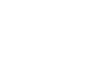


tóxicos;

- $\quad$ Aumento de bens e serviços [104].

Para o desenvolvimento sustentável faz-se indispensável à manutenção de parcerias que podem resultar em manutenção e conservação ambiental, social e inovações tecnológicas que trará como conseqüência o desenvolvimento industrial que completariam o ciclo da vida de produtos. É importante também a colaboração de todos os segmentos da sociedade inclusive o relacionamento entre países desenvolvido e em desenvolvimento [109].

\section{Economia Sustentável}

Vasconcelos [112] define economia sustentável como: "Economia é a ciência social que estuda como o indivíduo e a so- ciedade decidem

(escolhem)

empregar recursos produtivos escassos na produção de bens e serviços, de modo a distribuí-los entre as várias pessoas e os grupos da sociedade, para satisfazer as necessidades humanas". Essa ciência social tem que atender a dois princípios básicos: - Os recursos são limitados

$\begin{array}{cr}\text { e } & \text { escassos; } \\ \text { As } & \text { necessida- }\end{array}$

des humanas são ilimitadas e se renovam sempre. Diante desse paradoxo, é inevitável atendermos a conceitos importantes que são a base e o objeto do estudo da Ciência Econômica: escolha; escassez; necessidades; recursos; produção e distribuição. A atenção aos conceitos fundamentais que permitem a sustentabilidade foi sendo distorcida

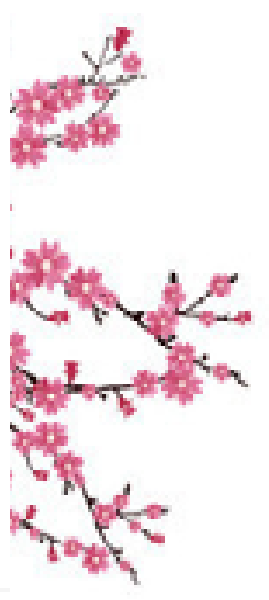




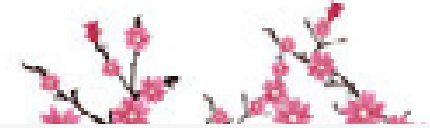

em função da criação da socie- dade de consumo, onde não se busca mais a satisfação da necessidade do homem, mas criam-se necessidades para crescimento da produção e aumento do lucro. Quando refere-se a ações individuais, domésticas, particula-

res, mantêm o foco nas ações e seu desenvolvimento. Podemos até considerar os processos desenvolvidos, mas seria um exagero analisar esses processos detalhadamente. Por outro lado, considerando grandes populações, empresas, governos, os processos são importantes e decisivos para os resultados que queremos ou vamos obter. Aspectos mais específicos da economia seus princípios sempre privilegiaram o menor custo em vista da viabilidade econômica da produção. Um processo

que gaste mais matéria prima ou mão de obra é preterido em função de outro mais eficiente. Por outro lado, se o processo é mais barato, menos eficiente, produz muito mais resíduo, mas mesmo assim mais lucrativo por questões de mercado, ele é preferido em relação a um processo mais limpo e sustentável. Uma economia sustentável tem que caminhar no conhecimento e prática de processos naturais. Os processos naturais foram selecionados durante milhões de anos. Privilegiam o consumo mínimo de energia e matéria prima com máximo de produtividade ao longo do tempo. A produtividade natural é real e não forçada por um período desejado.

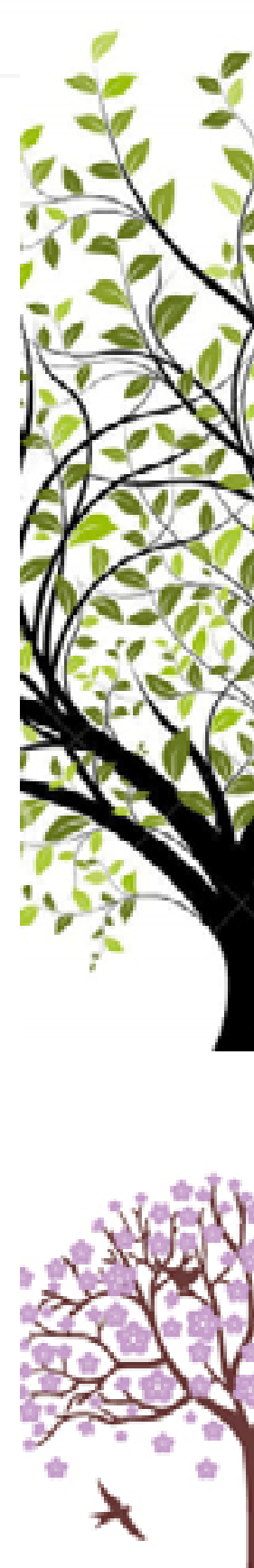




\section{Indicadores de}

\section{Sustentabilidade}

Desde fins da década de 80 os indicadores de desenvolvimento sustentável (IDS) vêm sendo construído, a partir da Rio-92, a segunda conferência das Nações Unidas sobre o Meio Ambiente e Desenvolvimento, que reconheceu sua importância por meio da Agenda 21, com objetivo de guiar as ações e monitorar o progresso em direção ao desenvolvimento sustentável (DS). Os IDS analisam as condições ambientais, sociais, econômicas e institucionais de um local, enfocando de forma multidimensional o desenvolvimento sustentável [112]. Em 1993 ocorreu encontro sobre Indicadores Ambientais e de Desenvolvimento e Sustentável, ocorrido em Genebra, organiza- do pelo United Nations Environmental Program (UNEP) e o governo holandês que possui um programa de indicadores ambientais desde 1991 permitindo um monitoramente efetivo das ações de desenvolvimento, agilizando a tomada de decisões e tendo uma importante participação popular no processo [113]. 0 capítulo 40, da agenda 21 , aborda a necessidade da construção de indicadores que contemplem a realidade de cada país para a tomada de decisões. Podemos citar três gerações, no processo de construção de indicadores de Desenvolvimento Sustentável: - Primeira geração: formado pelos indicadores ambientais clássicos que não possuíam interrelações entre os componentes de um sistema, como por

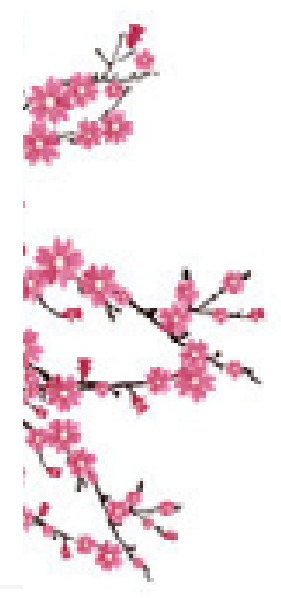




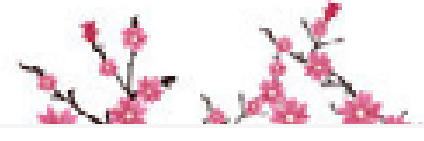

exemplo: emissões de $\mathrm{CO2}$, um meio de representar, as de- desmatamento, erosão, quali- corrências das várias atividadade das águas, entre outros; des humanas de um grupo, bem - Segunda geração: com- como as relações dessas decorpostos por quatro dimensões: rências, cujo objetivo principal econômica, social, institucional e ambiental, sem estabelecerem vinculações entre os temas;

consiste em agregar e quantificar informações ressaltando sua significância, visando melhorar :

Terceira geração: esses indicadores incorporam simulo processo de comunicação e entendimento dos fenômenos taneamente vários atributos complexos. As principais funou dimensões do desenvolvimento sustentável, as variáveis escolhidas têm que possuir correlação muito clara com os demais, pois fazem parte de um sistema como um todo [114]. Os indicadores devem ser entendidos como variáveis, ou seja, a representação operacional de um atributo (qualidade, característica, propriedade) de um sistema, a expressão indicador de sustentabilidade refere-se a ções dos indicadores são os de comparar lugares e situações, avaliar condições e tendências em relação às metas e aos objetivos, prover informações de advertência, e antecipar futuras tendências. Construir indicadores de sustentabilidade é um ato complexo porque os mesmos devem refletir a relação da sociedade com o meio ambiente numa ampla perspectiva, considerando os múltiplos fatores en-

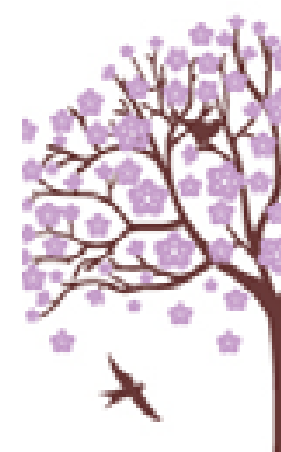


volvidos no processo $[115,116]$. humana e suas conseqüências, Os indicadores de sustentabili- pois tem a capacidade de abordade representam o futuro pre- dar os diferentes segmentos: visível a partir do conhecimento social, ambiental e econômico disponível, considerando as va- de forma conjunta [116,118]. riáveis do contexto no qual um grupo vive, as atividades desse grupo e as decorrências dessas atividades para todo o sistema. Os indicadores de sustentabilidade também têm o papel adicional de informar e orientar indivíduos, empresas, ou grupos a reconhecerem que o comportamento e escolha de cada um têm efeitos sobre o estado da sustentabilidade que se busca [117]. Estes também comunicam 0 progresso em direção a uma determinada meta de uma forma simples e objetiva, bem como objetivo retratar a realidade, enfatizando os fenômenos que tenham ligações entre a ação

\section{Sistema de Indicadores}

de Sustentabilidade

Os indicadores de sustentabilidade mais utilizados por cientistas e políticos á partir de 2000 como ferramenta para mensurar o desenvolvimento sustentável são a Pegada Ecológica (Ecological Footprint Method), o Painel da Sustentabilidade (Dashboard of Sustainability) e o Barometro da Sustentabilidade (Barometer of Sustainability). De acordo com Van Bellen esses indicadores representam informações relativas a toda a população global ou delimita grupos como nações, estados,
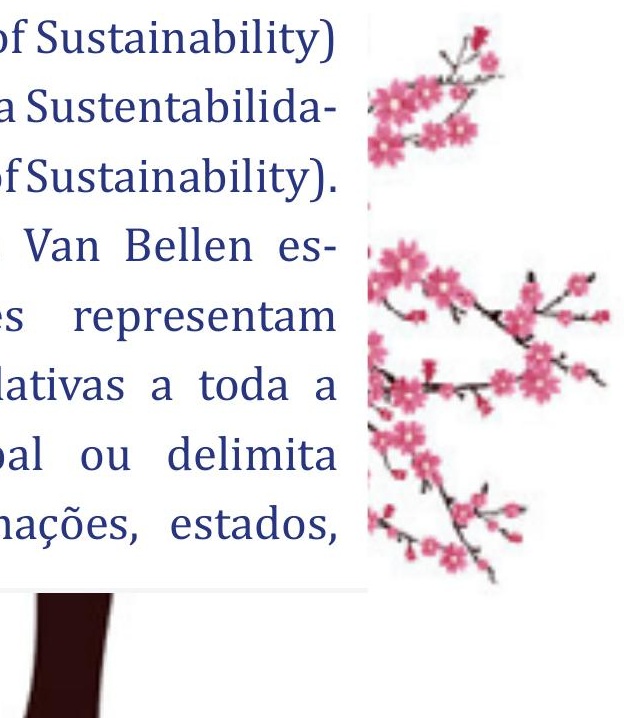


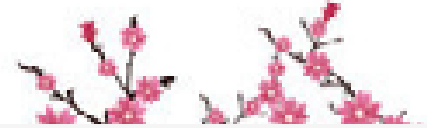

cidades, bairros, organizações

- e mesmo o comportamento de um indivíduo .No Brasil, o Instituto Brasileiro de Geografia e Estatística (IBGE) trabalha com 59 indicadores de sustentabilidade, que esta baseado nos 58 indicadores da Comission se deve adotá-los sem que os mesmos estejam contextualizados na analise a ser realizada. O indicador Pegada Ecológica nos permite ter uma visão clara das implicações transformando hectares em área biológica produtiva necessária para manter os hábitos de vida de uma população ou de um indivíduo específico. Temos hoje uma área de aproximadamente 1,9 hectares para cada habitante do planeta Terra, já no Brasil a média de consumo é de 2,39 hectares de área útil necessária em função do padrão de vida. Enquanto que nos Estados Unidos esta área hoje é de 9,57 hectares por habitante, analisando criticamente, para estas condições se todos os habitantes do planeta tivessem os mesmos padrões de vida de um americano precisaríamos

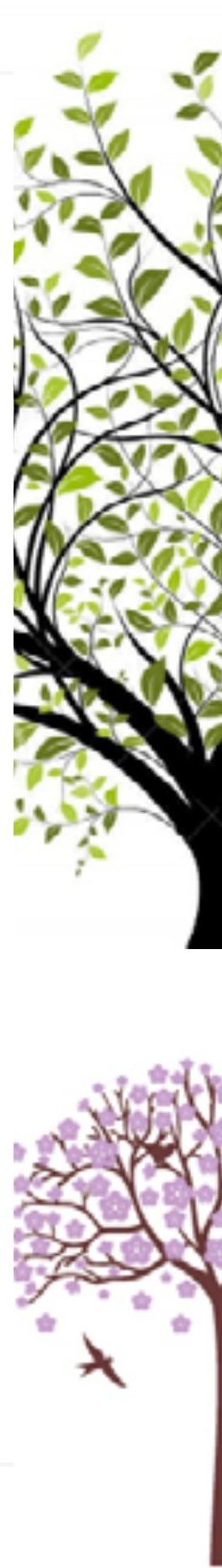


de pelo menos quatro planetas Terra para a população atual. 0 indicador Pegada Ecológica leva em consideração, para o seu cálculo da área para manter uma determinada população ou sistemaeconômico, os seguintes itens: - $\quad$ energia e recursos naturais;

a capacidade de absorção de resíduos e dejetos do sistema.

Para o cálculo da área necessária para a sustentabilidade baseia-se em:

- Cálculo da média anual de consumo em termos de terra

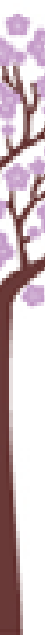

$\bullet$

A área total é obtida multiplicando a área média pelo número de habitantes da região; - As áreas representam usos exclusivos e cada hectare representa uma quantidade produtiva de biomassa, elas se somam ao total que reflete a demanda humana;

- $\quad$ A área total para a demanda humana pode ser comparada à oferta ambiental, uma vez que também é possível avaliar a área biologicamente produtiva do planeta $[114,117]$.

Para que este indicador seja padronizado são utilizadas médias nacionais de consumo e médias mundiais de produtividade da terra para que assim possamos obter padrões de consumo e produtividade que auxiliam na elaboração dos modelos de gestão. Este indicador explora

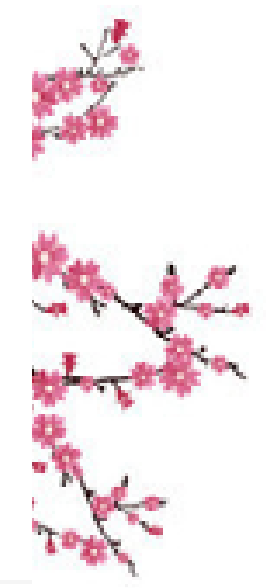




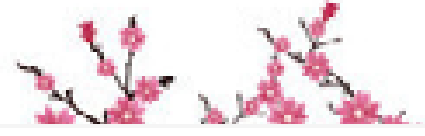

a relação sociedade e meio

ambiente e considera que para alcançar a sustentabilidade, um sistema precisa levar em consideração o tempo e a capacidade de regeneração dos ecossistemas [120].

Uma constatação da pegada eco-

* lógica é que o grau de exploração de recursos naturais e produção de resíduos dependem, em grande medida, dos padrões de consumo das sociedades. Devemos considerar que a pegada ecológica varia com relação ao tamanho da população, à média de consumo por pessoa, à intensidade de uso e recursos e também à capacidade do homem em construir artifícios para reutilizar os recursos e tratar os resíduos e dejetos do processo [144].

\section{Indicador de Controle da}

\section{Sustentabilidade}

Este indicador é constituído de medidas agregadas em três dimensões da sustentabilidade: a econômica, a social, e a ambiental de um país, cidade, município ou região. Seu conceito é o índice agregado de indicadores contidos em cada um dos mostradores, que é obtido pelo resultado final do cálculo de índices de cada mostrador. A representação gráfica do indicador é semelhante a de um painel de controle de um carro, com três mostradores, um para cada dimensão, a motivação para o seu uso foi criar uma ferramenta robusta que tivesse uma aceitação internacional [115,116, 121]. A seguir estão listados alguns indicadores constantes no pai-

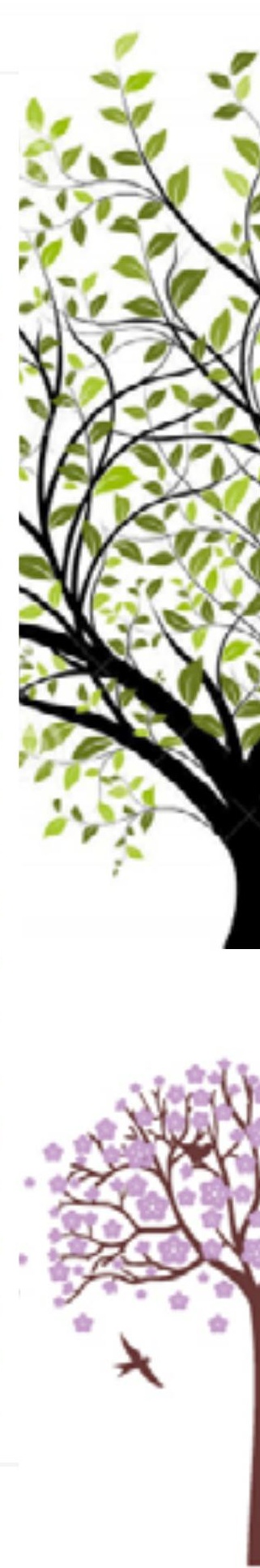


nel nas dimensões ecológica, resumem as características de econômica e social [119,116]: um sistema ou realçam algum - Dimensão Ecológi- ponto desse sistema. Este ínca: qualidade da água, do ar, dice pode ser utilizado para do solo, níveis de lixo tóxico; comparar nações como re-

Dimensão Econômica: giões e área urbanas [120]. emprego, investimento, produtividade, distribuiçõ de receitas, inflação e utilização eficiente de materiais e energia; - Dimensão Social: alfabetização, moradia, violência e população, crime, saúde, mortalidade, nutrição, condições sanit;arias, água tais, tomadores de decisões, e potável, educação, pobreza, indivíduos atuando na área do governança, gastos militares desenvolvimento sustentável e cooperação internacional. Constituídos de medidas agregadas as três dimensões: econômica, social e ambiental, este indicador é definido pelos seus idealizadores como unidade de informação que

\section{Barômetro da}

\section{Sustentabilidade}

O Barômetro da Sustentabilidade ou Barometer of Sustainability) foi desenvolvido para auxiliar agências governamentais e não governamenà nível nacional, regional, essa ferramenta tem com objetivo de avaliar sustentabilidade de um sistema econômico, foi desenvolvida pelo The World Conservation Unit (IUCN) e o International Development Re-

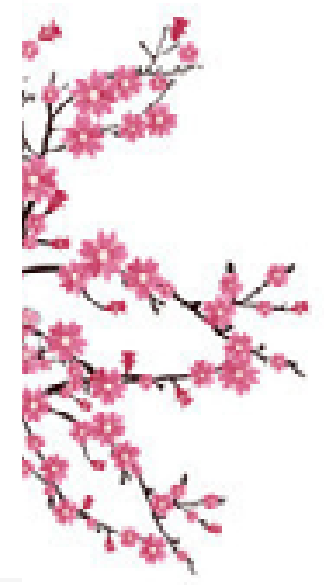




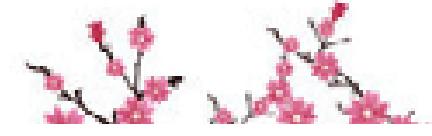

search Centre (IDRC). Este in-

dicador permite a combinação

* de indicadores e chega a seus resultados por meio de índices, mensurando os aspectos mais representativos do sistema por meio de indicadores do meio ambiente e do bem $\Rightarrow$

120 estar da sociedade [120, 121]. Uma das medidas mais utilizadas para avaliar a sustentabilidade é a monetarização, enquanto o Barômetro da Sustentabilidade integra indicadores biofísicos e da saúde social, para avaliar o progresso rumo a sustentabilidade, baseada em indicadores de grande variedade de questões ou dimensões, tais como qualidade da água, emprego, economia, educação, crime e violência. 0 Barômetro cumpre a função de avaliar, simultaneamente, as dimensões sociais e ecológicas do desenvolvimento sustentável [116, 120]. 1. Para os elaboradores do Barômetro de Sustentabilidade, o conceito do desenvolvimento sustentável pode ser entendido por meio de quatro etapa interligadas [119,120]:Globalidade: as pessoas fazem parte do ecossistema e, portanto devem ser considerados conjuntamente e ter igual importância no modelo de sustentabilidade; 2. Levantamento de Questões: Devido a falta de conhecimento sobre as relações entre as diferentes dimensões do desenvolvimento sustentável, deve-se levantar questões relevantes que possam esclarecer a natureza e a intensidade destas interações; 3. Instituições Reflexivas: 0 contexto institucional das

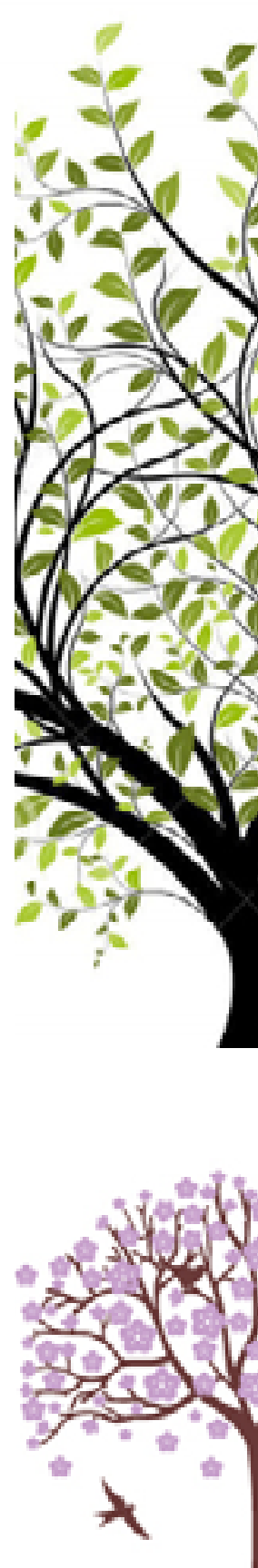


questões a serem analisadas exige uma abordagem conjunta de todas as pessoas envolvidas na elaboração do indicador; 4. Foco nas Pessoas: Ao elaborar o indicador devem-se levar em consideração que as pessoas são as fontes tanto dos problemas quanto de suas soluções. 0 indicador deve fornecer informações que possibilitem a motivação e a influência das pessoas em suas abordagens na integração do bem estar entre elas e o meio ambiente.

\section{Aplicações}

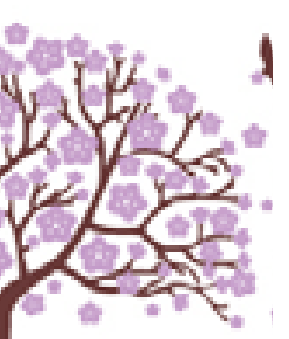

\section{Sustentáveis}

Podemos observar que hoje os mais diversos setores possuem ou buscam implantar indicadores, para que possam apresentar padrões de qualidade competitivos. Qualquer empreendimento humano para ser considerado sustentável deve de forma equilibrada atender quatro requisitos básicos como a adequação ambiental, viabilidade econômica justiça social e aceitação cultural. Baseado nessas premissas a Associação Brasileira dos Escritórios de Arquitetura - AsBEA e o Conselho Brasileiro de Construção Sustentável CBCS

e outras instituições apresentam diversos princípios básico da construção sustentável, nos quais podemos destacar [122]: Aproveitamento de condições naturais locais; Utilizar mínimo terreno e integrar-se ao meio ambiente natural; Implantação e análise do entorno; Não provocar ou reduzir impactos no entorno - paisagem, temperaturas e concentração de ca

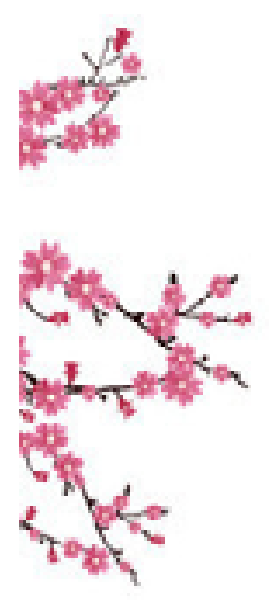




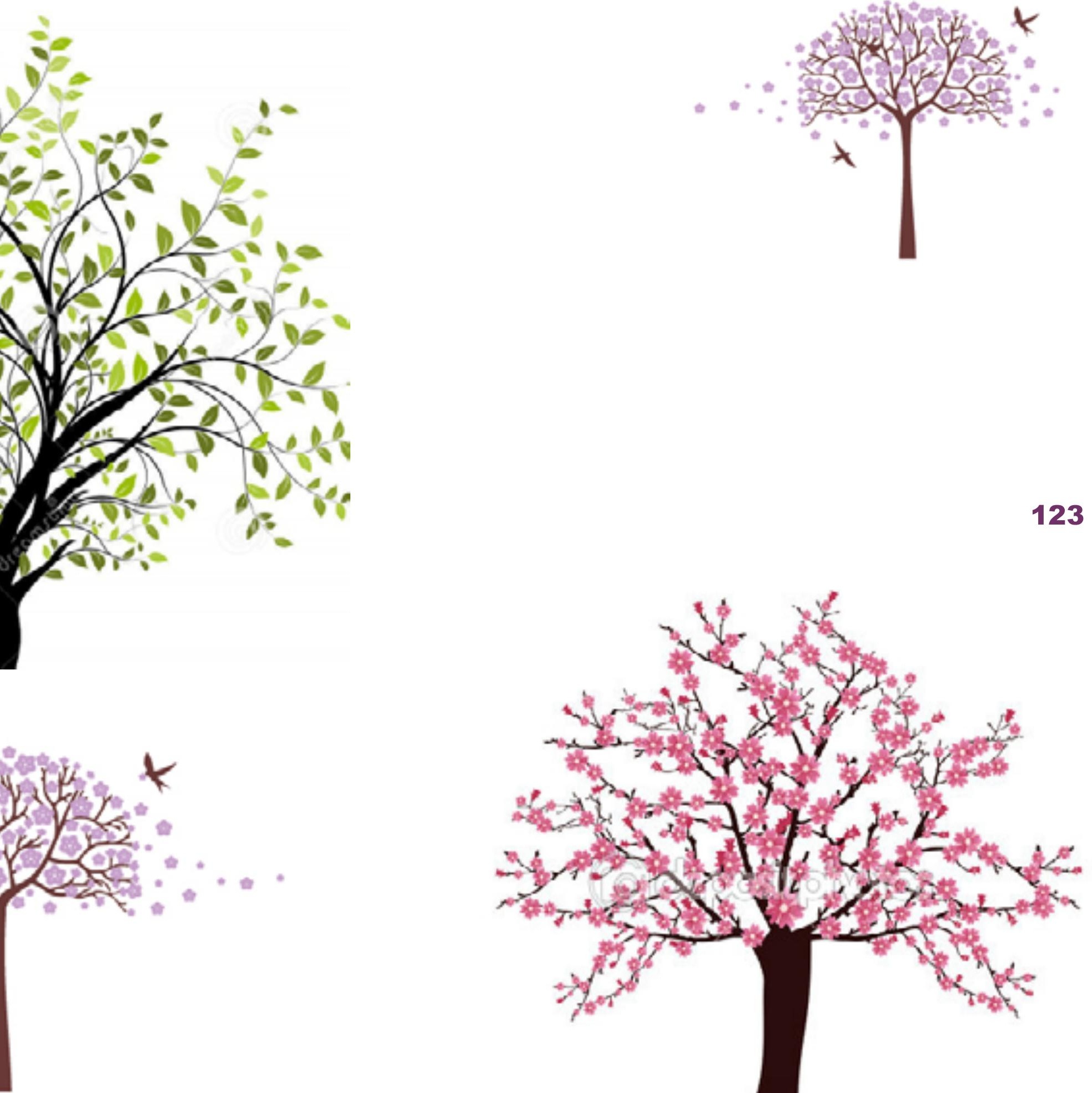




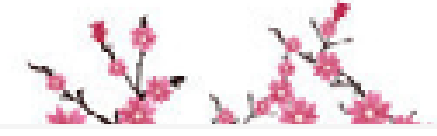

SUSTENTABILIDADE E

I EDUCAÇÃO AMBIENTAL

Em junho 1972, a Organização das Nações Unidas (ONU) promoveria a "Conferência da ONU sobre o Ambiente Humano" mais conhecido como "Conferência de Estocolmo", reunindo 113 países com a finalidade de estabelecer uma visão global e princípios comuns para a preservação e melhoria do ambiente humano. Considerada um marco histórico-político internacional, que possibilitou o surgimento de políticas de gerenciamento ambiental. A Conferência gerou a "Declaração sobre o Meio Ambiente", estabeleceu um "Plano de Ação Mundial", e ainda, propôs que deveria ser criado um Programa Internacional de Educação Ambiental. Diante das propostas feitas na Conferência de Estocolmo, em 1975, a UNESCO (Organização das Nações Unidas para a Educação, a Ciência e a Cultura) realizou em Belgrado (Iugoslávia), o "Encontro Internacional sobre Educação Ambiental”, reunindo 65 países. Foram propostos princípios e orientações a fim de se criar um Programa Internacional de Educação Ambiental, em que esta deveria ser contínua, multidisciplinar, ligada às diferenças de cada região e interesses nacionais. Neste encontro foi criada a Carta de Belgrado, voltada para a necessidade de uma nova ética global, que objetivasse o fim da pobreza, da fome, do analfabetismo, da poluição e da exploração humana.

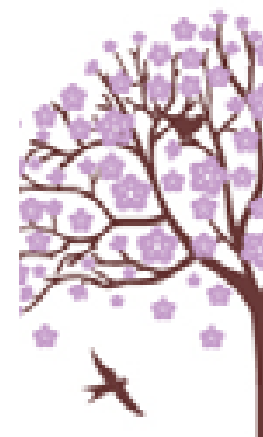


Em um trecho da carta é discutido que os recursos do mundo deveriam ser utilizados de um modo que beneficiasse toda a humanidade e proporcionasse a todos a possibilidade de aumento de qualidade de vida, este conceito viria a ser tratado mais tarde como Desenvolvimento Sustentável. Em outro trecho da carta é ressaltado um programa mundial de Educação Ambiental: “(...) devem ser lançadas as fundações para um programa mundial de Educação Ambiental, que possa tornar possível o desenvolvimento de novos conhecimentos e habilidades, valores e atitudes, visando à melhoria da qualidade ambiental e, efetivamente, à elevação da qualidade de vida para as gerações presentes e futuras" [123]. Ainda em 1975 em decorrência das discussões geradas a partir da carta de Belgrado, realizou-se em Tbilisi, na Geórgia (ex-União Soviética), a Primeira “Conferência Intergovernamental sobre Educação Ambiental", promovida pela UNESCO juntamente com o Programa das Nações Unidas para o Meio Ambiente (Pnuma). A Conferência contou com a participação de especialistas do mundo inteiro, para discutir propostas feitas em vários encontros sub-regionais, e ainda, definiu os princípios, objetivos e características da Educação Ambiental. Esta teria como finalidade promover a compreensão da existência e importância nas esferas política, econômica, social e ecológica da sociedade; dar às pessoas a possibilidade de adquirir conhecimentos, valores, interesse ativo e atitudes que
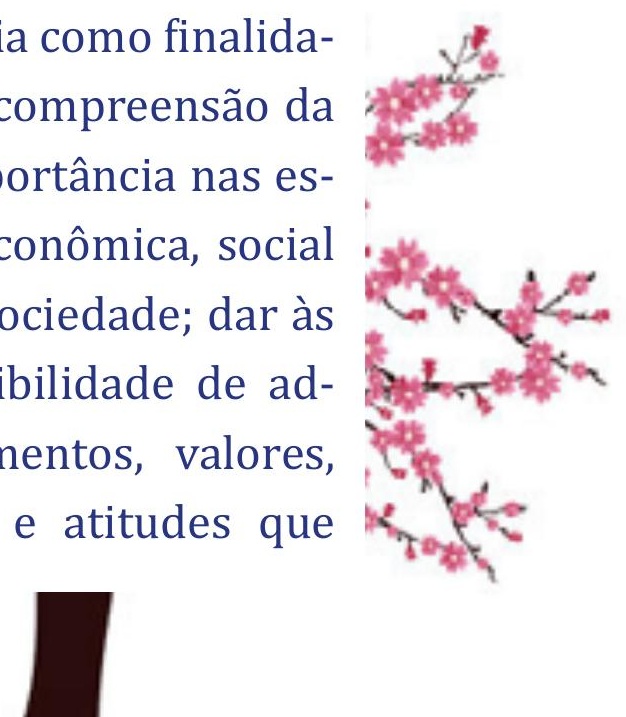


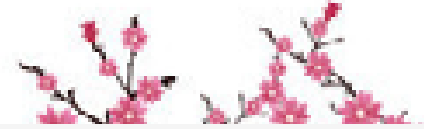

contribuiriam para proteção e

os objetivos destacados para a melhora da qualidade do meio educação ambiental, estavam: ambiente; gerar novas maneia promoção da conscientizaras de conduta dos indivíduos, ção, transmissão de informagrupos sociais e na sociedade em seu conjunto, possibilitando a ação em busca de alternativas de soluções para os seus proble-

mas ambientais, melhorando, assim, a qualidade de vida [124]. Após mais de dez anos, em 1987, realizou-se em Moscou o “Congresso Internacional sobre Educação e Formação Ambiental", promovido pela UNESCO juntamente com o Pnuma, com a finalidade de analisar o desenvolvimento da Educação Ambiental desde a Conferência Intergovernamental sobre Educação Ambiental (Tbilisi -1975), e estabelecer uma estratégia internacional de ação para a década de 90. Dentre ções, novos hábitos e habilidades, valores, estabelecimento de critérios e padrões, e direcionamento para a resolução de problemas e tomada de decisões. Em 1992, ocorreria então a "Conferência das Nações Unidas sobre o Desenvolvimento e o Meio Ambiente", realizado no Rio de Janeiro, que ficaria conhecida como RIO-92/ ECO-92. Esta contou com a participação de 175 países, e em termos de Educação Ambiental propôs esforços para a erradicação do analfabetismo ambiental e para as atividades de capacitação de recurso humanos para a área. Por meio da Agenda 21, a Rio92 corroborou com o proposto

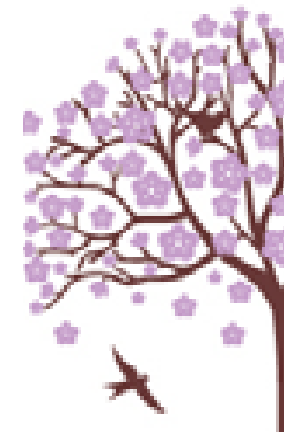


em Tbilisi, e propôs enfoque nas seguintes áreas: reorientação da educação para o desenvolvimento sustentável, aumentar os esforços para promover a conscientização popular e erradicar o analfabetismo ambiental. Durante a realização da Rio-92 foi assinada e elaborada pelos membros dos países participantes a Agenda 21 Global, um documento de 40 capítulos que teve como objetivo primordial um novo padrão de desenvolvimento para o planeta no século XXI, denominado, então, de "desenvolvimento sustentável". Documento foi elaborado baseado em mudanças na educação ambiental, conciliando proteção ambiental, justiça social e economia, a fim de garantir a sustentabilidade da vida. Segundo o próprio documento da Agen- da 21: "Agenda 21 está voltada para os problemas prementes de hoje e tem o objetivo, ainda, de preparar o mundo para os desafios do próximo século. Reflete um consenso mundial e um compromisso político no nível mais alto no que diz respeito a desenvolvimento e cooperação ambiental. A responsabilidade e o envolvimento dos Governos são fundamentais para o êxito de sua execução, para concretizá-la, são cruciais as estratégias, os planos, as políticas e os processos nacionais. A cooperação internacional deverá apoiar e complementar tais esforços nacionais. Nesse contexto, o sistema das Nações Unidas tem um papel fundamental a desempenhar. Outras organizações internacionais, regionais e subregionais também são convidadas

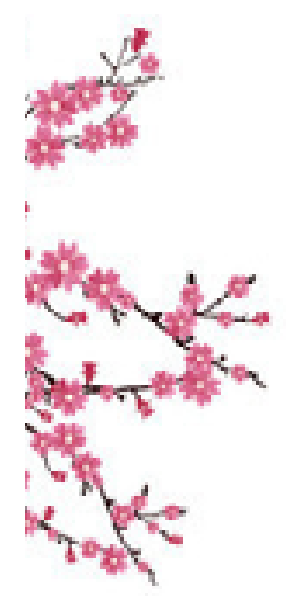




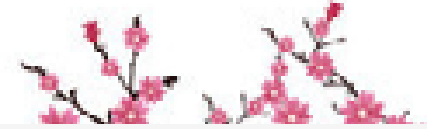

a contribuir para tal esforço. A Por ocasião da Rio-92, foi elabo\ mais ampla participação pública e o envolvimento ativo das organizações não governamentais e de outros grupos também devem ser estimulados" [125]. Ainda conforme o próprio documento: "A Agenda 21 é um pro* grama dinâmico. Ela será levada a cabo pelos diversos atores segundo as diferentes situações, capacidades e prioridades dos países e regiões e com plena observância de todos os princípios contidos na Declaração do Rio sobre Meio Ambiente e Desenvolvimento. Com o correr do tempo e a alteração de necessidades e circunstâncias, é possível que a Agenda 21 venha a evoluir. Esse processo assinala o início de uma nova associação mundial em prol do desenvolvimento sustentável" [124].

rado em junho de 1992 o "Tratado de Educação Ambiental para Sociedades Sustentáveis e Responsabilidade Global", com base nas recomendações de Tbilisi e no documento Cuidando do Planeta Terra - uma estratégia para o futuro da vida, escrito pela União Internacional para a Conservação da Natureza (UICN), Programa das Nações Unidas para o Meio Ambiente (Pnuma) e pelo Fundo Mundial para a Natureza (WWF), em 1991. Dentre os princípios apresentados destacaram-se: a Educação Ambiental como preconizadora da transformação e construção da sociedade; a Educação Ambiental deve estabelecer a relação homem, natureza e universo de forma interdisciplinar; a Educação Ambiental

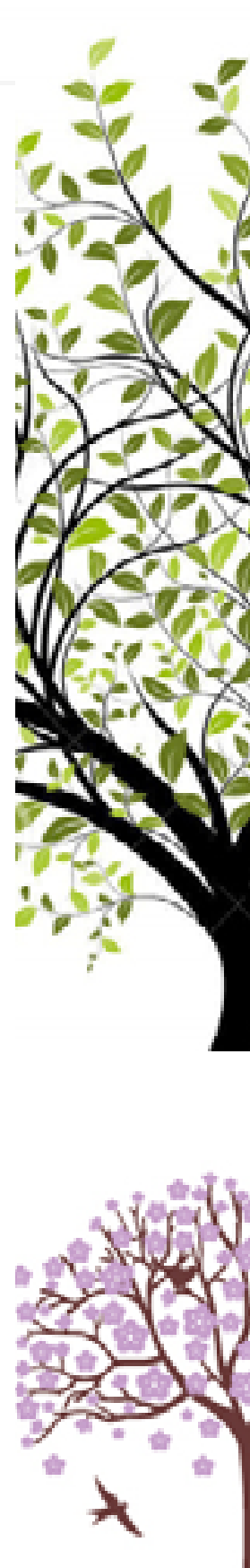


deve ajudar no desenvolvimento de uma consciência ética sobre todas as formas de vida. Após 20 anos de Tbilisi, em 1997, foi realizada a "Conferência Internacional sobre Meio Ambiente e Sociedade: Educação e Conscientização Pública para a Sustentabilidade" promovida pela UNESCO em Tessalonik (Grécia), contando com participantes de mais de 83 países. Nesta, foi proposta a reorientação da educação visando a sustentabilidade, estando relacionada não só com o meio ambiente, mas também com a pobreza, habitação, saúde, segurança alimentar, democracia, direitos humanos e paz, sendo ressaltado também o padrão de consumo adotado pelas pessoas [125]. Conforme o documento da Conferência: "A fim de atingir a sustentabilidade, uma enorme coordenação e integração de esforços é necessária em diversos setores cruciais e uma mudança rápida e radical em comportamentos e estilos de vida, incluindo mudança no padrão de consumo e produção. Para isso, uma educação apropriada e conscientização pública devem ser consideradas os pilares da sustentabilidade, juntamente com legislação, economia e tecnologia". 0 documento também afirma que a sustentabilidade é um imperativo moral e ético no qual a diversidade cultural e o conhecimento tradicional precisam ser respeitados [124].

\section{Educação Ambiental:}

um Caminho para

\section{Sustentabilidade}

A educação é um ato de

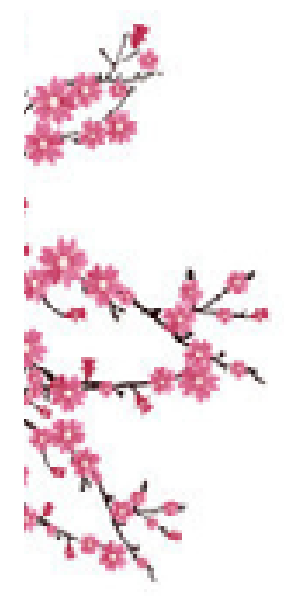




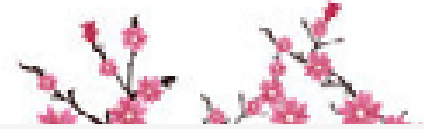

conhecimento, pois por meio te injusto e devastador [128].

- dela é possível obter uma vi- Ela se coloca numa posição consão do mundo que seja crítica trária ao modelo de desenvolvida realidade. A conscientização deve estar ligada a um processo ação-reflexão, em que o indivíduo toma conhecimento da realidade por meio da razão, mento econômico existente no sistema capitalista, em que os valores éticos, de justiça social e solidariedade não são considerados, nem a cooperação é esti* lançando um olhar mais crítico em relação à realidade [126] mulada, apenas prevalecendo o lucro a qualquer preço, a comA Educação Ambiental propõe

a reconstrução da sociedade para uma nova relação com o meio ambiente [123], assumindo um papel de transformadora, na qual a corresponsabilização dos indivíduos torna-se o objetivo principal na promoção do desenvolvimento sustentável [127], ampliando reivindicações sociais, denunciando todo um modelo e processo de desenvolvimento econômico, responsável por um contexto socialmenpetição, o egoísmo e os privilégios de poucos em detrimento da maioria da população [129]. Acerca disso Silva e Taglieber (2006) afirmam que vivemos em uma sociedade em que os valores estão ligados aos bens adquiridos, à complexa rede social contemporânea avança para a cultura do consumo, direcionada ao lucro e ao acúmulo de bens materiais [130]. As práticas voltadas para a educação ambiental garantem

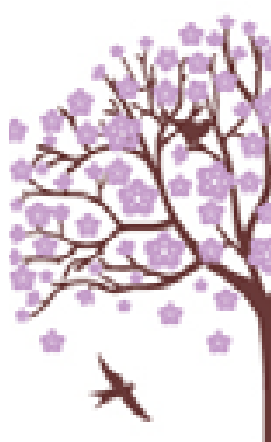


meios de criar novos estilos de vida e promovem uma consciência ética que questione o atual modelo de desenvolvimento, caracterizado pela ação predatória e pelo reforço das desigualdades sócios ambientais [127]. Segundo Dias et. al. (2004) “Educação Ambiental é um processo permanente no quais indivíduos e as comunidades tomam consciência de seu meio ambiente e adquirem conhecimentos, valores, habilidades, experiências e determinação que o tornem aptos a agir e resolver problemas ambientais, presentes e futuros." [131]. A participação, a organização, a educação e o fortalecimento das pessoas são condições necessárias para que se chegue ao desenvolvimento. Deve ser apropriado não só aos recursos e ao meio ambiente, mas também à cultura, história e sistemas sociais do local onde ocorre [132]. A educação voltada para o desenvolvimento sustentável deve voltar-se para a aprendizagem de atitudes, perspectivas e valores que orientam e impulsionam as pessoas a viverem suas vidas mais sustentavelmente. Educar para o desenvolvimento sustentável é educar para se tomar consciência da irresponsabilidade do ser humano frente à questão ambiental, a fim de superá-la [133]. 0 tema sustentabilidade confronta-se com o paradigma da transformação de um planeta, não apenas crescentemente ameaçado, mas também afetado pelos riscos socioambientais e seus danos, é cada vez mais notória, a concepção "sociedade de risco". Isto implica na necessida-
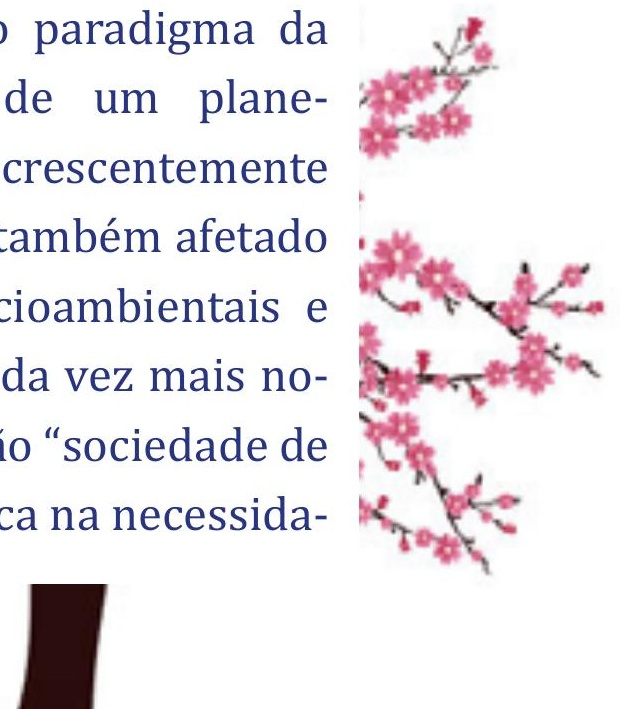


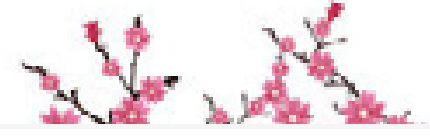

de de se multiplicarem as práti-

contribuição da educação am-

\section{- cas sociais baseadas no direito de} acesso à informação e à educação ambiental. A multiplicação dos riscos, principalmente ambientais e tecnológicos, são elementos para que se possa entender as características, os limites para a sustentabilidade [134]. Deste modo, se tornam necessárias ações que levem a promoção de sociedades mais sustentáveis, de cidadãos mais conscientes de seu papel perante a sociedade e ao ambiente, e neste aspecto a biental é de suma importância. Pedrini \& Brito (2006) analisam as possibilidades pedagógicas que podem ser criadas abordando comportamentos, atitudes e ações generalizadas direcionadas a um projeto de sociedade baseado na eficiência econômica, prudência ecológica e justiça social em uma sociedade de risco devido à modernidade [135]. O caminho para que uma sociedade se torne sustentável se fortalece na medida em que se desenvolvam práticas educativas que pautadas pelo paradigma da complexidade, tragam para a escola e os ambientes pedagógicos, uma atitude reflexiva em torno da questão dos problemas ambientais, e os efeitos causados por uma sociedade pragmática e utilitarista,

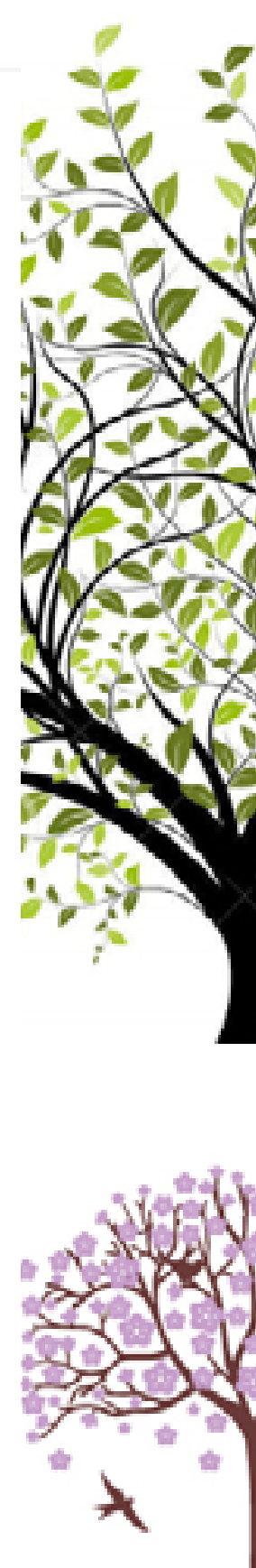


com o objetivo de formar novas mentalidades, conhecimentos e comportamentos [134]. Diante desse aspecto, pode-se analisar que a educação ambiental torna-se um elemento determinante para a formação de cidadãos, uma vez que educa para a cidadania, revendo valores e atitudes que possam contribuir para ações sustentáveis [135]. A educação ambiental surgiu com uma visão fundamentalmente política despertando o exercício da cidadania, formando pessoas que assumam seus direitos e responsabilidades sociais, formando cidadãos que adotem uma atitude participativa e crítica nas decisões da vida cotidiana, a fim de que se possa transformar a sociedade em busca de um presente e um futuro melhor [136].
A educação ambiental tida como um processo político e pedagógico deve formar para o exercício da cidadania, desenvolvendo conhecimento interdisciplinar baseado em uma visão integrada do mundo. Tal formação fornece subsídios para que cada pessoa investigue, reflita e aja sobre efeitos e causas dos problemas ambientais que afetem a sua qualidade de vida. A interdisciplinaridade é importante no sentido de superar a fragmentação das diferentes áreas do conhecimento, buscando pontos de convergência e propiciando a relação entre os vários saberes [137]. A educação voltada para a questão ambiental pode contribuir para o equilíbrio entre o homem e a natureza, construindo uma ética ambiental que assegure uma educação sistematizada, li-

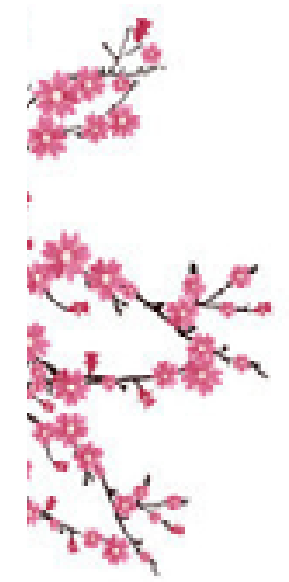

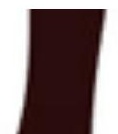




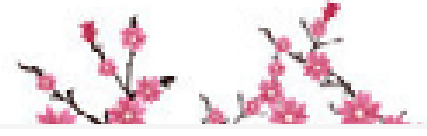

gada ao contexto cultural da comunidade, levando em conta os aspectos políticos econômicos, sócio-culturais, científicos, tecnológicos e éticos [135]. Ações que busquem o equilíbrio entre o bem estar dos homens e a preservação dos recursos naturais,

parte de um processo educativo que enfatize um pensar da educação e dos educadores voltados para a sustentabilidade [128]. 0 processo educativo deve ser ca- paz de formar um pensamento crítico e ligado com a necessidade de buscar respostas para o futuro, capaz de analisar as relações entre os processos naturais e sociais e de atuar no meio ambiente em uma perspectiva global. Neste aspecto, o papel dos educadores é de extrema importância para impulsionar as transformações de uma educação que assume um compromisso com a formação de valores de sustentabilidade, como parte de um processo coletivo na construção do conhecimento do cidadão para com suas responsabilidades ambientais [134]. É necessário priorizar a importância da qualidade de vida nas cidades e regiões, fortalecer a importância de garantir padrões ambientais adequados e estimular uma consciência ambiental

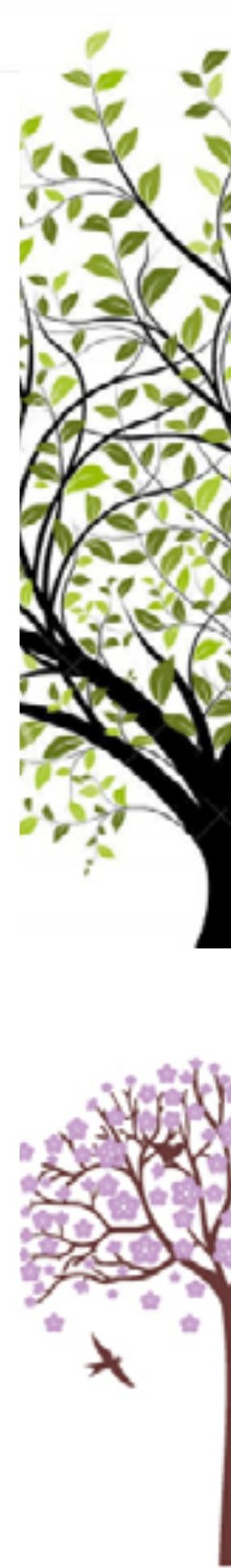


focada no exercício da cidadania

ferentes soluções, conceituar e na reformulação dos valores e executar um plano de ação, éticos e morais, individuais e coletivos, numa perspectiva voltada para a sustentabilidade [116]. A educação ambiental procura conscientizar os indivíduos para a adoção de atitudes e comportamentos mais sustentáveis, desta forma, reduzindo o consumo, reaproveitando e reciclando os materiais, economizando água, energia, recursos naturais, formando cidadãos comprometidos com a causa ambiental e capaz de intervir na vida social, pública e política [117]. Neste contexto, as estratégias educativas que auxiliam a resolução de problemas são favorecidas com frequência. 0 aprendizado essencial inclui identificar, analisar e diagnosticar um problema, pesquisar e avaliar di-

avaliar os processos e assegurar que a educação para o desenvolvimento sustentável possa promover o uso criativo e efetivo do potencial humano e todas as formas do capital para garantir um crescimento mais rápido e justo, com menor impacto sobre o meio ambiente [139]. Gadotti e et.al. (2007) afirmam que uma educação para o desenvolvimento sustentável deve ser holística, transdisciplinar, crítica, construtiva, participativa, ou seja, uma educação guiada pelo princípio da sustentabilidade [133]. Pode-se observar que a educação ambiental é um processo que pode fornecer aos cidadãos uma compreensão crítica e global do meio ambiente, demonstrando valores e atitudes que

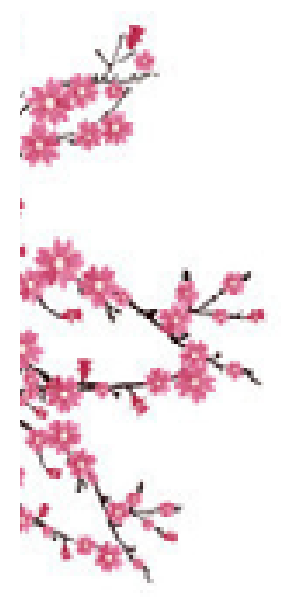




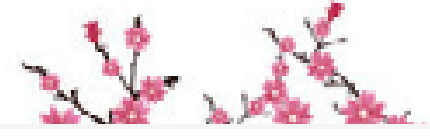

lhes proporcionem uma toma-

natureza e busca a compreensão „ da de posição consciente e pardos problemas ambientais na ticipativa no que diz respeito escola e no seu entorno [123]. às questões ligadas com a pre- Refletir sobre a complexidaservação e adequado uso dos de ambiental abre espaço para recursos naturais [140]. Desta forma, proporcionando o pleno exercício da cidadania, pela forum processo educativo articulado e compromissado com a sustentabilidade, questiona valores e premissas que norabrangente, técnica, e culturalmente capaz de permitir a superação dos obstáculos à utilização sustentada do meio [132]. A educação ambiental pressupõe a capacidade de aprender, criar e exercitar novas concepções e práticas de vida, da educação e de convivência individual, social e ambiental capazes de substituir os velhos modelos de esgotamento [141]. Baseando-se em um processo educativo voltado para a reflexão dos alunos a partir das relações com a teiam as práticas sociais hoje existentes, implicando na mudança na forma de pensar, uma transformação no conhecimento e das práticas educativas [134]. Gadotti e et. al. (2007) afirmam que para os sistemas educativos possam incorporar em seus processos pedagógicos a educação para o desenvolvimento sustentável, é necessário educar o cidadão conscientizando-o da necessidade da sustentabilidade ambiental [133]. Pensar em desenvolvimento

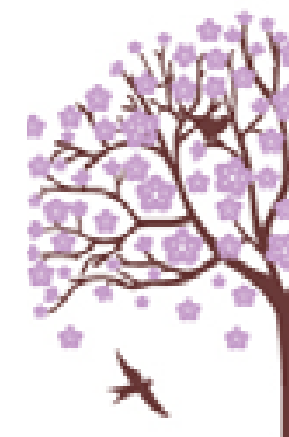


sustentável ou sustentabilidade pressupõe ações práticas e teóricas de Educação Ambiental. "educar ambientalmente" passa pela sensibilização a respeito da importância de ações ligadas à preservação e conservação do meio ambiente e do uso correto de seus recursos naturais [138]. A preservação do meio ambiente depende de uma consciência ecológica e a formação da consciência depende da educação. A educação, nas suas diversas possibilidades, cria um estimulante espaço que possibilita o repensar das práticas sociais e o papel dos educadores como mediadores de um conhecimento necessário para que os alunos possam compreender o meio ambiente global e local, a interdependência dos problemas e soluções e a impor- tância da responsabilidade de cada de construir uma sociedade mais igualitária e ambientalmente sustentável [133]. Reconhecer as questões pertinentes à temática ambiental é fundamental na visão do mundo e do ambiente, que implicam em relações sociais e culturais. Tal compreensão proporciona aos educadores uma forma consciente e responsável para planejar estratégias pedagógicas e atividades para um melhor desenvolvimento das habilidades, atitudes e valores no ambiente escolar [123]. 0 grande desafio dos educadores ambientais é, de um lado, o resgate e o desenvolvimento de valores e comportamentos e de outro, os estímulos a uma visão global e crítica da temática ambiental e a promo-

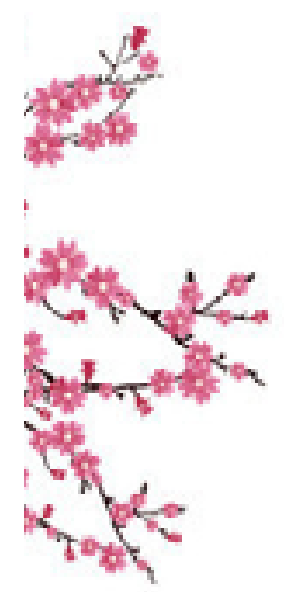




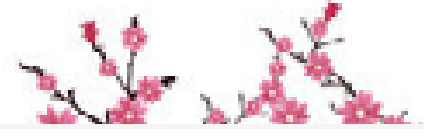

ção de uma abordagem inter- lizada por meio da educação disciplinar que possa resga- ambiental que possibilitará às tar e construir saberes [127]. pessoas a construção de conheDesta forma, a educação as- cimentos, valores, novas formas sume um papel importante de ser, dentro de uma nova étiquando associada à formação de cidadãos críticos conscientes de sua posição como agen* te transformador da sociedade, ajudando-os a conservar sua tradição cultural, novos valores éticos com o objetivo de alcançar a sustentabilidade em sua comunidade local, e ao mesmo tempo global. A educação ambiental marca uma nova função social da educação, não constitui apensa uma dimensão, nem um eixo transversal, mas é responsável pela mudança da educação com um todo, em busca de uma sociedade sustentável [125]. A construção de uma cidadania, portanto, poderá ser reaca, tornando-as aptas a estabelecer uma relação de causa e conseqüência dos problemas ambientais, discutir questões, fixar propriedades, tomar decisões, exercer sua representatividade, buscando o desenvolvimento sustentável [136]. Segundo Nunes (2009) "é preciso colocar, efetivamente, em prática, a Educação Ambiental - emancipatória, transformadora, participativa, abrangente, permanente, contextualizadora, ética e interdisciplinar". A Educação Ambiental mostra-se uma ferramenta capaz de auxiliar na mudança de comportamento e conscientização necessária para

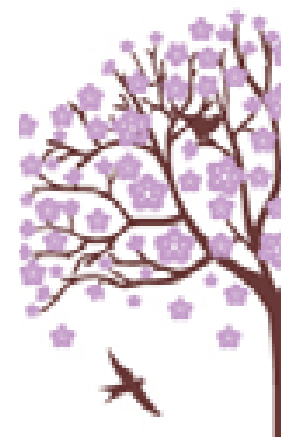


a sensibilização sobre ações e atitudes danosas da humanidade que estão comprometendo a prática da sustentabilidade [142]. A educação ambiental vem propor não apenas um papel, mas uma missão à educação: a de recriar a sociedade de uma forma mais justa e sustentável. Formando cidadãos capazes de atuar nas esferas da vida pública e política a fim de favorecer os processos de transformação social, promovendo mudanças nos modos de produção e consumo social, modificando estilos de vida e trabalhando visando a construção de uma sociedade ambientalmente mais equilibrada [128]. As práticas educativas voltadas para a temática ambiental são ferramentas, que podem contribuir na revisão da postura dos homens frente ao modelo de vida adotado no último século, caracterizado pela utilização da natureza de modo predatório e indiscriminado. 0 repensar de atitudes e valores frente a essa situação proporciona aos indivíduos a decisão por optar por ações mais sustentáveis em suas vidas.

A educação ambiental abre caminhos que possibilitam a construção de sociedades mais sustentáveis, mais compromissadas com as questões ambientais e com suas próprias vidas. Diminuindo, desta forma, o risco e a vulnerabilidade existentes nas sociedades, atualmente. A educação ambiental como prática é uma via de acesso que pode contribuir ao verdadeiro modo de vida sustentável.

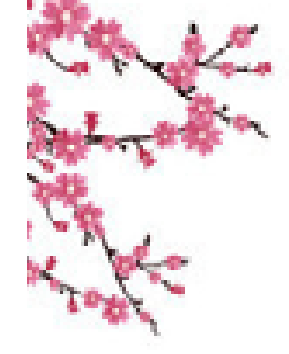


cação Ambiental, pois atuará de forma profunda nas pessoas, levando em conta aspectos culturais, regionais. Geralmente estes aspectos, não só nas questões ambientais, estão gravados na memória, nos costumes, na cultura do indivíduo ou da coletividade. A educação ambiental seria o fim e a psicologia o meio. A educação ambiental nada mais é do que a própria educação, com sua base teórica determinada historicamente e que tem como objetivo final melhorar a qualidade de vida e ambiental da coletividade e garantir a sua sustentabilidade [144]. A psicologia ambiental atuará na mudança de paradigmas para trazer a compreensão de novos conceitos de crescimento, desenvolvimento e da ligação entre a vida das pessoas e do meio ambiente como um todo. Desta forma fará a sociedade perceber-se no contexto do meio ambiente e mudar os hábitos de vida. A psicologia ambiental sugere que o ser humano precisa de uma relação de maior proximidade com o seu lugar. Sentir-se pertencendo a algum lugar possibilita a criação de um vínculo afetivo com ele [145].

\section{Pesquisas da}

\section{Associação Americana de} Psicologia - APA

A Associação Americana de Psicologia (APA) realizou um estudo para entender porque as pessoas estão demorando tanto para perceber que devem se engajar no combate às mudanças climáticas. Essa responsabilidade se dá principalmente por motivos comportamentais, como
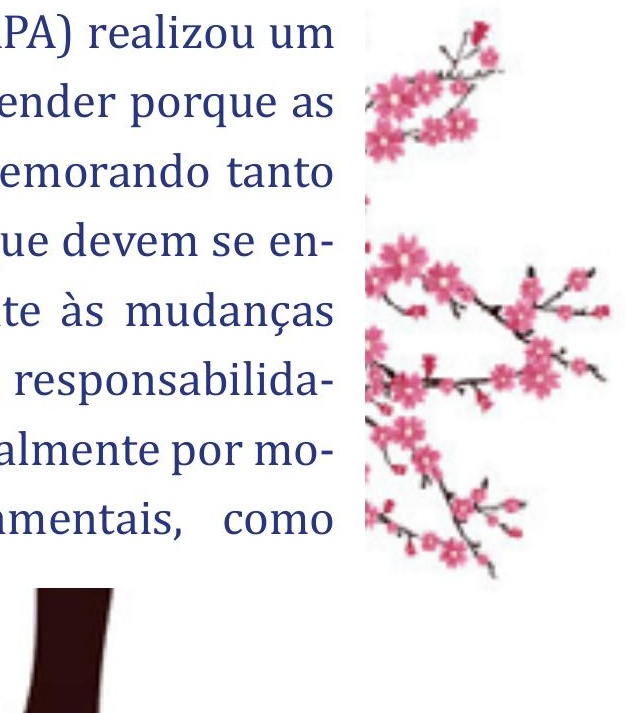


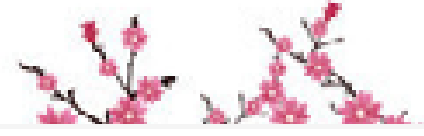

o consumo de energia e o crescimento populacional e mostra que a psicologia deveria exercer uma função maior nessa luta. 0 trabalho "Psychology and Global Climate Change: Addressing a Multi-faceted Phenomenon and Set of Challenges"

* examina décadas de pesquisas e práticas psicológicas que foram utilizadas em áreas ligadas com as mudanças climáticas, como meio ambiente conservação e desastres naturais [146]. Os cientistas e ambientalistas alertam que para minimizar os efeitos das mudanças climáticas as pessoas deveriam mudar imediatamente seus hábitos, entretanto o cidadão comum simplesmente não tem esse sentimento de urgência. Entre os fatores citados pelo estudo da APA para essa falta de vontade de querer agir estão: desconhecimento, desconfiança, negação, a sensação de que elas sozinhas não influem no cenário maior e pura e simplesmente a recusa para alterar antigos hábitos. A APA destacou algumas maneiras de como a psicologia já está trabalhando para ultrapassar essas barreiras. A entidade reconheceu, por exemplo, que as pessoas utilizam mais aparelhos com boa eficiência energética se a economia deles for clara e imediata. Os equipamentos que mostram o quanto de energia e de dinheiro estão economizando são mais procurados pelos consumidores. Outro exemplo prático que é citado pelo estudo é um programa de adoção de sistemas mais eficientes de controle de temperatura de residências, e consequen-

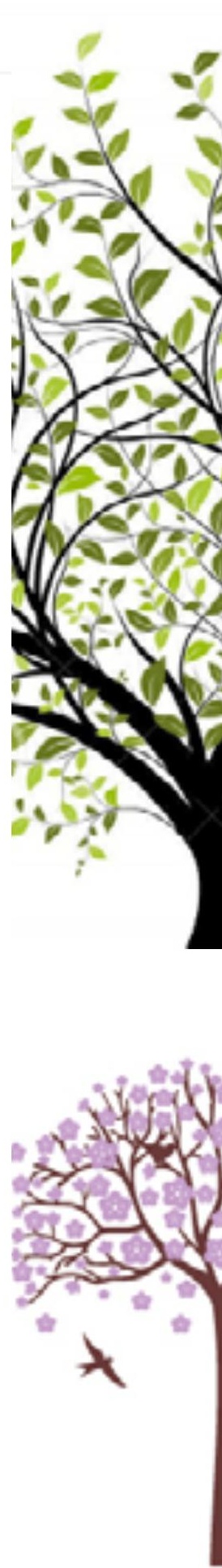


temente a redução do consumo energético, cerca de $20 \%$ das pessoas aderiu maior quantidade, do que as que contaram apenas com incentivos financeiros. Outras áreas que a psicologia poderia ajudar são no desenvolvimento de leis ambientais, programas de incentivos econômicos, tecnologias de eficiência energética e métodos de comunicação. A Educação usada junto com a Psicologia Ambiental será importante no desenvolvimento do "pensamento sustentável". Somos escravos de uma visão reducionista, que muitas vezes relega à natureza a função de apenas nos suprir de alimentos, energia, matéria-prima e belas paisagens. Viver de forma sustentável - em equilíbrio com o meio ambiente - não é uma questão de esti- lo, mas de sobrevivência [147].

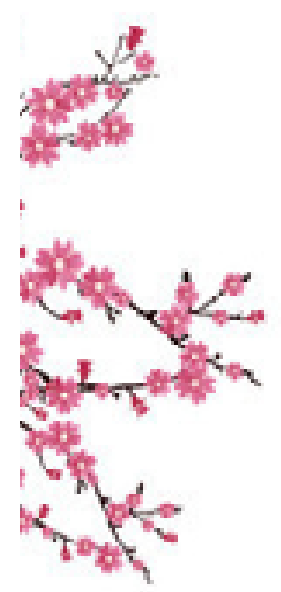




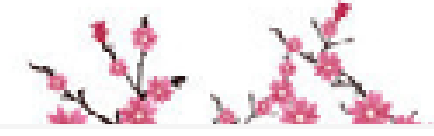

REFERÊNCIAS

3 1. MAI, L. A.; CARNEIRO, A. L. G.; SABUNDJIAN, G. Disciplina TNR 5768 Energia e Desenvolvimento, Slides utilizados em aula, IPEN/CNEN- SP, 2008

2. TESSMER, H. Uma síntese histórica do consumo de ener* gia pelo homem. consultado em abril de 2013. http://www. liberato.com.br/upload/arquivos/0131010716090416.pdf.

3. Os efeitos da tecnologia no mercado de trabalho. Consultado em abril de 2013. www.ime.usp.br/is/ddt/.../fim.../revolucoes.htm.

4. UDAETA, M. E. M.; BURANI, G. F.; GRIMONI, J. A. B.; NYIMI, D. R. S. Energia. In: GRIMONI, J. A. B.; GALVÃO, L. C. R.; UDAETA, M. E. M. (Org.) Iniciação a Conceitos de Sistemas Energéticos para o Desenvolvimento Limpo, Cap. 3, p. 69-70, EDUSP, 2004.

5. História da Energia. Consultado em abril de 2013. http: //www.iconeong.org.br/historiadaenergia.htm.
6. TERREMOTO,
L. A.
A.
Apostila
Disciplina TNR5764 Fundamentos de Tecnologia Nucle-
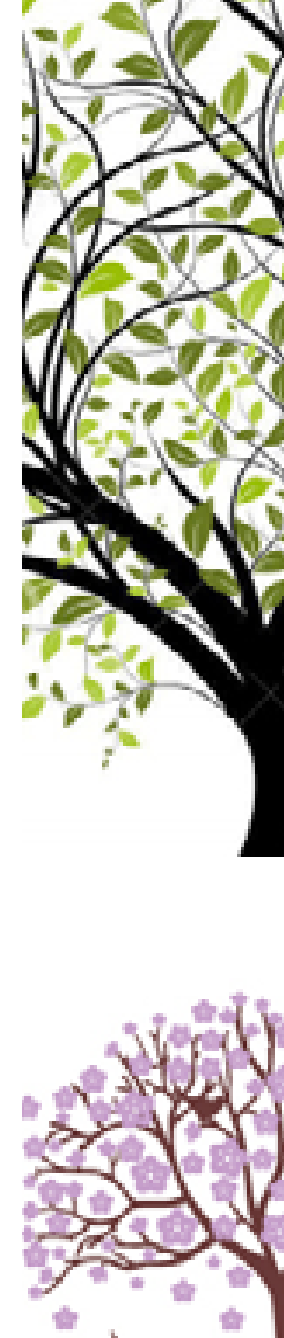
ar Reatores, Roteiro de Estudos, IPEN/CNEN- SP, 2004. 7. UDAETA, M. E. M.; BURANI, G. F.; GRIMONI, J. A. B.;NYIMI, D. R. S. Energia. In: GRIMONI, J. A. B.; GALVÃO, L. C. R.; UDAETA, M. E. M. (Org.) Iniciação a Conceitos de Sistemas Energéticos para o Desenvolvimento Limpo, Cap. 3, p. 67-96, São Paulo: EDUSP, 2004.

8. GALVÃO, L. C. R.; KANAYAMA, P. H.; BURANI, G. F.; UDAEDA, M. E. M. Aspectos Relevantes dos Sistemas Energéticos In: GRIMONI, J. A. B.; GALVÃO, L. C. R.; UDAETA, M. E. M. (Org.) Iniciação a Conceitos de Sistemas Energéticos para o Desenvolvimento Limpo, Cap. 9, p. 239-271, São Paulo: EDUSP, 2004.

9. Comitê de Energia e Sustentabilidade. Fontes de Energia. Consultado em abril de 2013. www.ufsm.br/cenergia/.

10. DREAD, G. Irradiando Luz. Sustentabilidade: Fontes de energia limpas ou renováveis? Disponível abril de 2013. http://irradiandoluz.blogspot.com/2009/10/ fontes - d e-energia-limpas - ou - renovaveis.htm l.

11. BEMELMANS, D. Energia Nuclear é sustentável? Acesso em abril de 2013. http://www.cened cursos.com.br/energia-nuclear-sustentavel.html.
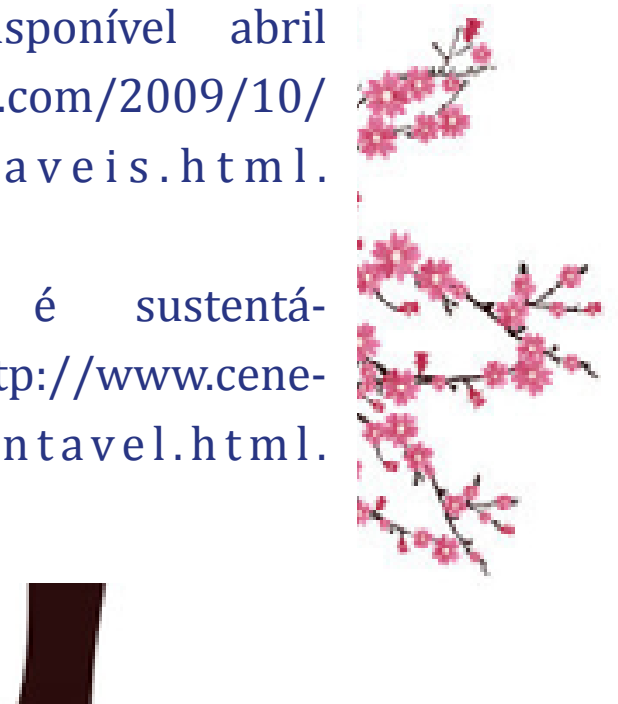


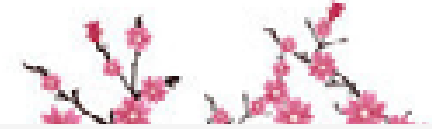

12. AFFONSO, F. O., PElegrinI, M. A.; GALVÃO, L. C. R.; UDAETA, M. E. M. Recursos Energéticos Naturais In: GRIMONI, J. A. B.; GALVÃO, L. C. R.; UDAETA, M. E. M. (Org.) Iniciação a Conceitos de Sistemas Energéticos para o Desenvolvimento Limpo, Cap. 4, p. 99-127, São Paulo: EDUSP, 2004.

13. FUJII, R.J.; GIMENES, A. L.V.; PENTEADO JUNIOR, A. A.; UDAETA, M.E.M.Produção deEnergiaIn:GRIMONI,J.A.B.; GALVÃO, L.C.R.; UDA-

ETA, M. E. M. (Org.) Iniciação a Conceitos de Sistemas Energéticos para o Desenvolvimento Limpo, Cap. 5, p.129-155,São Paulo: EDUSP, 2004.

14. SCALAMBRINI, C. Renováveis: A energia que o mundo precisa. Revista Sustentabilidade. Acesso em abril de 2013. http:// www.revistasustentabilidade.com.br/s02/artigos/renovaveis-a-energia-que-o-mundo-precisa-por-heitor-scalambrini-costa/.

15. AGENEAL - Agência Municipal de Energia de Almada. Energias Renováveis. Aceso em abril de 2013. http://www.ageneal.pt/content01.asp?BtreeID =00/01\&treeID $=00 / 01 \& a u x I D=\&$ news ID = 8\&offset $=\#$ content

16. CAVALCANTE, R. 0 vilão virou herói. Super interessante. Editora Abril. ed. 241, p. 60-69, julho 2007.

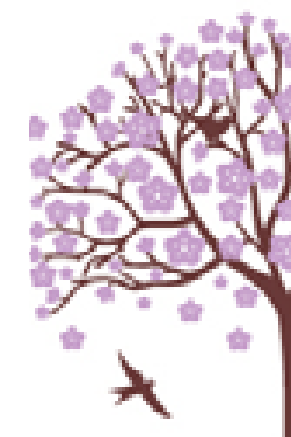




\section{Energia \\ Hidráulica \\ Consultado \\ março \\ de \\ 2013. \\ http://www.portalsaofrancisco.com.br/alfa/}

energia-hidreletrica / energia-hidreletrica-2.ph p.

18. MEDINA, B. M. O. Biocombustível - Biólogo. Disponível em abril de 2013. http://www.biologo.com.br/ecologia/ecologia8.htm. 19. Dissertação apresentada na Faculdade de Ciências e Tecnologia da Universidade Nova de Lisboa para obtenção do grau de Mestre em Bioenergia, 2009. Consultada março 2013. http://hdl.handle.net/10362/3363.

20. BAITELO, R. L.; AFFONSO, O. F.; GIMENES, A. L. V.; UDAETA, M. E. M. Transporte de Energia In: GRIMONI, J. A. B.; GALVÃO, L. C. R.; UDAETA, M.E. M. (Org.) Iniciaçãoa Conceitos deSistemas Energéticos para o Desenvolvimento Limpo, Cap. 6, p. 159-189, São Paulo: EDUSP, 2004.

21. VEJA, Perguntas e Resposta Aquecimento Global, Junho de 2007. http://www.painelsolartermico.com/sistemas-solares-termicos/. Consultado março de 2013.

22. Alexandre Daniel Sousa Santos. Avaliação de Sistemas Solares Térmicos de Produção de Água QuenteSanitária em Edifícios de Habitação Multifamiliar, Dissertação para obtenção do Grau de Mestre em Engenharia Mecânica,Universidade Técnica de Lisboa, cap. 2, 2012.
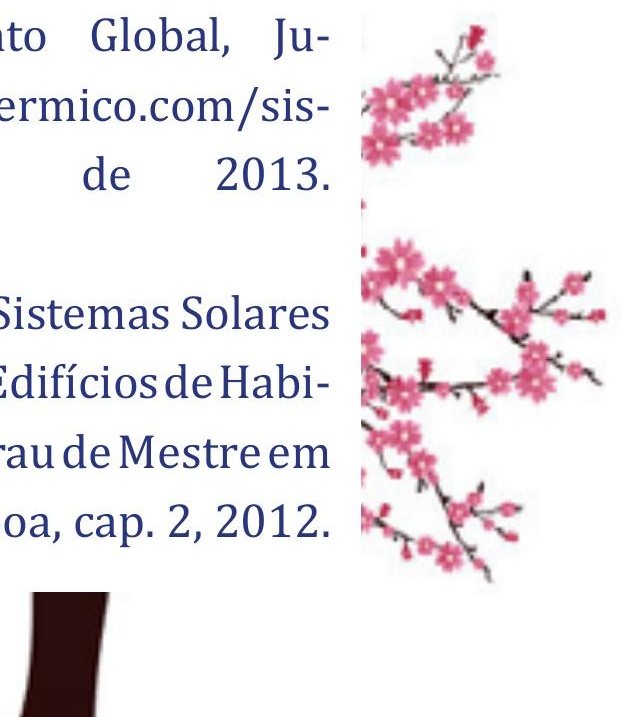


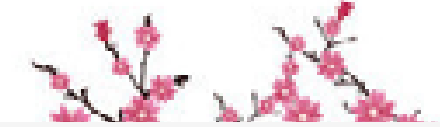

23. A Energia Solar. Principio de funcionamento. Acesso em abril de 2013. http://educar.sc.usp.br/licenciatura/1999/princ.html.

24. WALD, M. L. O Charme e o Poder das Renováveis. Scientific American, n 32, p. 8-13, 2009.

25. http://wwwnovas.blogspot.com.br/2009/02/ energia-geotermica.html. Consultado março

2013.

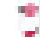

26. NISHIZ, M. H. et. al, Influencia dos Créditos de Carbono na Viabilidade de Financeira de Três Projetos Florestais, Viçosa-MG, v. 29, p. 263-270, 2005.

27. Tecnologia de Energia das Ondas Consultado março 2013. http://www.energiasealternativas.com/energia-ondas.html.

28. GONÇALVES, O. D. A promissora potencialidade nuclear do Brasil. Scientific American, n 32, p. 22- 27, 2009.

29. Água I: Escassez de Água Potável para Consumo Humano. Consultado em abril de 2013. http:// pt.shvoong.com/exact-sciences / 1923016 -\%C3\%A1 gua-escassez-\%C 3\%A 1gua-pot\%C 3\%A1vel-para /

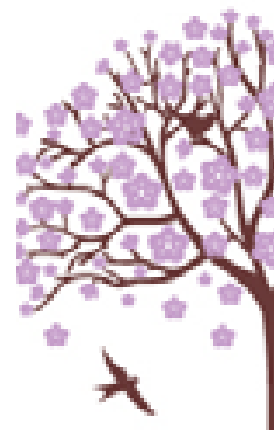


30. NASCIMENTO, K. O fator nuclear: caminho para a sustentabilidade energética. Consultado em abril de 2013. http://www.pm.al.gov.br/bpa/publicacoes/fator_nuclear.pdf.
31. CAPOZZOLI,
U.
Energia
e
Civiliza-
ção. Scientific
American,
$\mathrm{n}$
32 ,
p.
3 , 2009.

32. Rumbo_port.pdf. Disponível em 19/10/2009. http://www. stephanschmidheiny.net/files/file/books/P-6-Mudando\%20.

33. SILVA, C. L.; MENDES, J. T. G. Reflexões Sobre o Desenvolvimento Sustentável. Agentes e Interações sob a Ótica Multidisciplinar. Editora Vozes, Petrópolis, 2005.

34. GUELBER,T.T.F.etal.AEmbalagemPETeaReciclagem:umaVisão Econômica Sustentável para o Planeta, Foz do Iguaçu, PR-Brasil,2007.

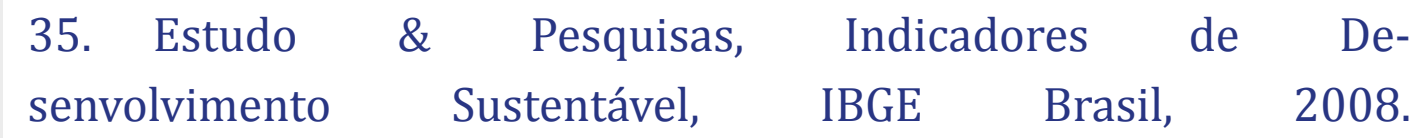

36. Indicadores de Desenvolvimento Sustentável - Brasil 2010 Consultado março 2013. http://www.ibge.gov.br/ home/geociencias/recursosnaturais/ids/default_2010.shtm.
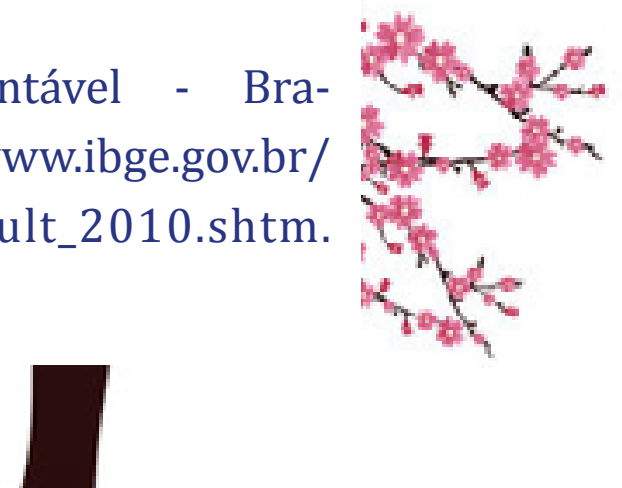


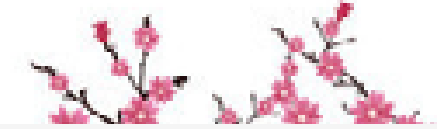

37. Plano Brasil participação e inclusão. Consultado março de 2013. http://www.planobrasil.gov.br/texto_base.asp?cod=5.

38. Sustentabilidade empresarial, econômica-social-ambiental Consultado março de 2013. http://www.responsabilidadesocial.com/article/article_view.php?id=1377

39. Propostas para um Sistema de Indicadores de Sustentabili: dade de Desenvolvimento Sustentável, ISBN 972-8419-48-1, 2000.

40. Indicadores de Desenvolvimento Sustentável, IBGE Brasil,2008.

41. Efeito Estufa - Brasil Escola. Consultado en abril ade 2013. http://www.brasilescola.com/geografia/efeito-estufa.htm.

42. Metano na atmosfera. Consultado em abril de 2013. http://www.biotecnologia.com.br/revista/bio07/metano.pdf. 43. Entenda o Protocolo de Kyoto. Consultado em abril de 2013. http://revistaepoca.globo.com/Epoca/0,6993,EPT 908417 -1655,00.html.

44. Conferência de Bali busca acordo climático global em 2009. Consultado em abril de 2013. ww w.c ardioprime.med.br/noticias.php?id $=45$.

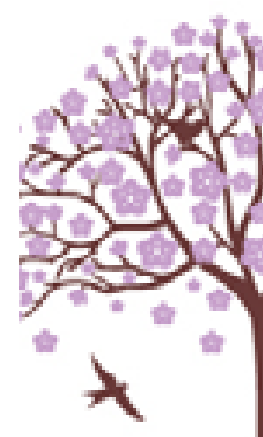


45. Conferência de Bali chega a um acordo. Consultado em abril de 2013. http://g1.globo.com/Noticias/Ciencia.

46. Decisão de Diretoria no 254/2012/V/I, de 228-2012. Consultado março 2013. http://www.cetesb.sp.gov.br/proclima/inventario-de-gee empreendimentos/384

-inventario-de-gee-empreendimentos.

47. CASTARANELI, E. H. Créditos de Carbono. Consultado em abril de 2013. www.unisalesiano.edu.br/encontro2007/.../P032103279808.pdf.

48. Brasil fecha maior contrato de crédito de carbono com alemão KFW 06/04/2006. Consultado em abril de 2013. http:// noticias.uol.com.br/ultnot/2006/04/06/ult29u47126.jhtm

49. MARENGO, J. A. Água e mudanças climáticas, Estudos avançados. v. 22 n 63, 2008.

50. MILLER, T. G. JR. Ciência Ambiental, Tradução 11 $11^{a}$ edição norte-americana, 2006.

51. Os recursos de água doce no mundo - situação, normatização e perspectiva. Consultado em mar-

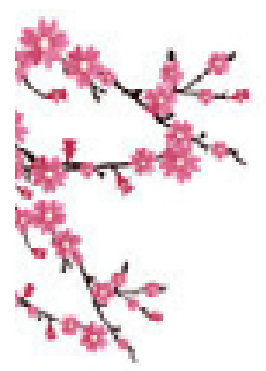


59. Meio Ambiente - Legislação. Consultado em abril de 2013.

http://www.antaq.gov.br/portal/MeioAmbiente_Legislacao.asp

60. John Evans. Monóxido de carbo-

no, Química Nova na Escola, n. 9, 1999.

61. Efeitos da Poluição do Ar. consultado em outubro de 2011 e em março de 2013. http://www.universoambiental.com.br/AR/Ar_Controle 7.htm.

62. Qualidade do ar Companhia Ambiental do Estado de São Paulo CETESB Consultado março de 2013. http://www.cetesb.sp.gov.br/ar/Informa??es-B?sicas/21Poluentes\#ozonio.

63. McLeod Ferreira, Tratamento de Efluentes de Laboratórios, Consultoria Técnica e Comercial S/C Ltda. Consultado em abril de 2013. http://www.cnpsa.embrapa.br/met/ images/arquivos/08MET/Palestras/tratamentoefluentes.pdf.

64. BARCELLOS, F. C. Indicadores ambientais: Modelo propositivo para o complexo industrial de Camaçari. Dissertação de Mestrado em Gestão Ambiental, Universidade Estácio de Sá, Rio de Janeiro 2000.

65. NBR 9.800/1987 - Critérios para lançamento de efluentes lí-

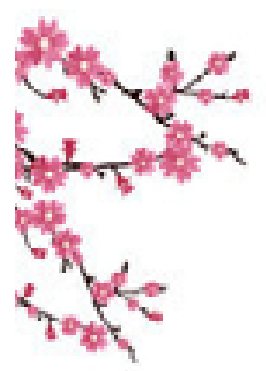




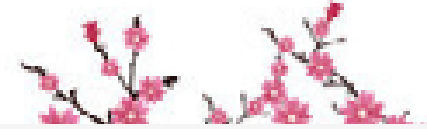

quidos industriais no sisteาma coletor público de esgoto sanitário.

66. CMMD. Comissão Mundial sobre Meio Amase biente e Desenvolvimento. Nosso Futuro Comum. ed. 2. Rio de Janeiro. Fundação Getúlio Vargas, 1991.

67. PINTO, T. P. De Volta à Questão do Desperdício. Construção. n. 2491, p. 18-19, 1995.

68. Efluentes Industriais, Consultado em abril de 2013. http://www.cimm.com.br/portal/material_didatico/3669-efluentes industriais \#.UWJCg1eRc7o.

69. Tipos de Tratamento de esgotos. Consultados em abril de 2013. www.casan.com.br/.../ete- es tacao-de-tratamento-de-esgotos-sanitarios

70. JORDÃO, E. P., PESSÔA, C. A. Tratamento de esgotos domésticos. 3. ed. Rio de Janeiro: ABES, p. 720, 1995.

71. MILANEZ, K. W. et al. Caracterização de pigmentos inorgânicos à base de $\mathrm{Fe}, \mathrm{Zn}$ e $\mathrm{Cr}$ utilizando resíduo de galvanoplastia como matéria-prima. Cerâmica, v.51, p. 107-110. 2005. 72. TORRES, D. P. C. Aspectos do tratamento biológico de es-

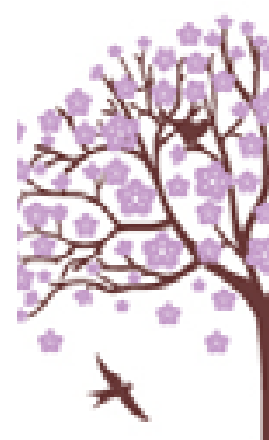


gotos domésticos. Revista Científica de IMAPES, p. 68-70, 2004.

73. CETESB Influência de agentes tóxicos no tratamento de esgotos por via biológica - Processo de lodo ativado. São Paulo, p. 31, 1986.

74. LEME, F. P. Engenharia do saneamento ambiental. ed. 2. LTC - Livros Técnicos e Científicos, 1984.

75. BRESAOLA, J. R.; CARRARA, S. M. C. M. Reuso de águas residuárias geradas em processos de galvanoplastia. XXVII Congresso Interamericano de Engenharia Sanitária e Ambiental, 1999.

76. PHILIPPI, J. A.; BRUNA, G. C.; ROMÉRO, M. A. Curso de Gestão Ambiental, Editora Manole, São Paulo, 2004.

77. ABNT (Associação Brasileira de Normas Técnicas) NBR 10004/87 - Classificação de Resíduos Sólidos. 1987.

78. Indicadores

to Sustentável

de

Brasileiro

DesenvolvimenIBGE,

2010.

79. MOURA, L. A. A. Qualidade e Gestão Ambiental - Sugestões para implantação das normas ISO 14.000 nas Empresas. Editora Oliveira Mendes, São Paulo,1998.

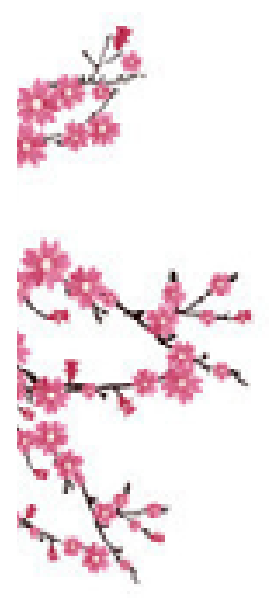




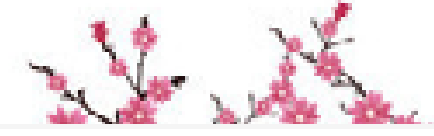

80. Programa de Coleta Seletiva do Instituto de Biociências da

1 Universidade de São Paulo, Consultado em abril de 2013. http:// www.ib.usp.br/coletaseletiva/saudecoletiva/reciclaveis.htm

81. SISINNO, C.L. S. e OLIVEIRA, R. M. Resíduos Sólidos, Ambiente e Saúde: uma visão multidisciplinar, São Paulo, Editora Fiocruz, 2000.

82. Suzaquim Indústrias Químicas Ltda, Acesso em \% abril de 2013. http://suzaquim.com.br/Processo.htm

83. ATIVA - Reciclagem de Materiais Ltda. Consultado em abril de 2013. http://www.ativareciclagem.com.br/.

84. Plano de gerenciamento integrado de resíduos pilhas, baterias, Consultado em abril de 2013. http:// www.minasmenosresiduos.com.br/doc/infoteca/Cadernos\%20Tecnicos/Cartilha-residuos-lampadas.pdf

85. ANNELISE E. G.; CAMILA R. O. Reciclagem do lixo de informática: uma oportunidade para a química, Química Nova, v. 35, p. 1486-1492, 2012.

86. Reciclagem de Computares - e-lixo - Sucata eletrônica. Consultado em abrila de 2013. http://www.inovacaotec-

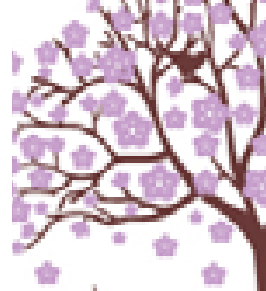


nologica.com.br/noticias/noticia.php?artigo=010125070309.

87. JACOBI,P.;BESEN, R.G.R.Gestão deresíduos sólidosemSãoPaulo: desafios da sustentabilidade, Estudos avançados, v. .25 n 71, 2011.

88. TRAMPPO RECICLA LÂMPADAS. Consultado em abril de 2013. http://www.tramppo.com.br/empresa.html.

89. Seminário Energia NuclearConsultado emabril de2013.http:// www.biofisica.ufsc.br/index.jsp?page=arquivos/rejeitos.html.

90. COMISSÃO NACIONAL DE ENERGIA NUCLEAR .

CNEN: Norma CNEN 6.05 - Gerencia de Rejeitos Radioativos em Istalações Radiotaivas - Rio de janeiro, p. 361985.

91. Compromisso Empresarial Para a Reciclagem - CEMPRE. Consultado em abril de 2013. http://www.cempre.org.br/.

92. Implantando um aterro sanitário. Consultado em abril de 2013. http://www.hfc.com.br/aterro2.htm\#Implantand o\% 20 um \% 20 Aterro\%20 Sanit \% C $\%$ A 1 rio.

93. A Busca de uma Agricultura Sustentável. Consultado em abril de 2013. http://www.cultivando.com.br/saude_meio_am-

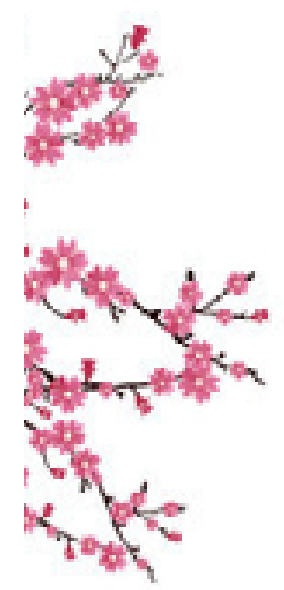




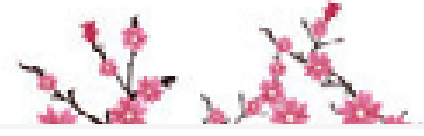

biente_agricultura_sustentavel_busca_da_sustentabilidade.html.

94. MARCATTO, C. Agricultura Sustentável: Conceitos e Princípios. Consultado em abril de 2013. www. ufpe.br/biofisica/images/Economia/aula23.doc.

95. A agricultura e o desafio da sustentabilidade, EMBRAPA. Consultado em abril de 2013. http://www.embrapa.br/ : imprensa/artigos/2007/artigo.2007-02-14.

96. ALMEIDA, J. R.; et al: AQUINO, A. R. et al. Gestão Ambiental Para o Desenvolvimento Sustentável. Rio de Janeiro: Thex Ed., 2006.

97. Mateus, E. F. et al. Aspectos Sócio Econômico e Ambientais das Agroindústiraias Familiares do Vale do Rio dos Sinos, RS, II Fórum Ambiental da Alta Paulista, 2006.

98. AlMEIDA, J. R.; et al AQUINO, A. R. et al. Perícia Ambiental judicial e securitária:impacto, dano e passivo ambiental - Rio de janeiro: Ed. Thex. 2006.

99. GALVÃO, A. S. Biodigestor Caseiro-Limpo-Prático-Eficiente, 1ạ Ed, Editora Biblioteca, 2009.

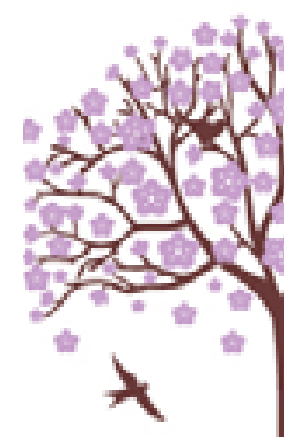




\section{Sustentabilidade}

e Agricultura.

Consulta-

da em abrila de 2013. http://www.webartigos.com/articles/5114/1/sustentabilidade-e-agricultura/pagina1.html.

101. PATERNIANI, E. Agricultura Sustentável nos Trópicos.Consultado em abril de 2013. http:// www.scielo.br/pdf/ea/v 15 n 43 / 15 n 43 a 23 .pdf.

102. ALTENFELDER, mento sustentável.
Ruy.

Gazeta
DesenvolviMercantil, 2004.

103. PHILIPPI, L. S. A Construção do Desenvolvimento Sustentável. In: LEITE, A. L. Tostes de Aquino; MININNI-MEDINA, Naná. Educação Ambiental (Curso básico à distância) Questões Ambientais - Conceitos, História, Problemas e Alternativa. ed. 2, v. 5. Brasília: Ministério do Meio Ambiente, 2001.

104. BRASIL. Ministerio do Meio Ambiente. Secretaria de Biodiversidade e Florestas. Brasília, DF, Junho de 2001.

105. ROCHA,

JN, H. GONTIJO, J. M.(org.)

106. PEREIRA, V. M. et al. Estudo da sustentabilidade e em-
DORRESTEIVolume $5, \quad 2006$.

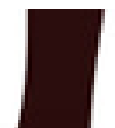




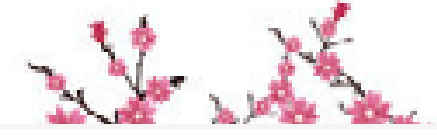

preendimento agroindustrial aplicando métodos e otimiza- ção, IV Simpósio sob recursos naturais e sócio-econômico de Pontal Carumbá/MS, 23 de nov. 2004. Consultado em abril de 2013. http://www.cpap.embrapa.br/agencia/simpan/sumario/artigos/asperctos/pdf/socio/313SC-RIGHI-OKVisto.pdf.

107. BELIK, W. Agroindústria e reestruturação industrial no brasil: elementos para uma avaliação. Consultado em abril de 2013. " http://seer.sct.embrapa.br/index.php/cct/article/view/9026.

108. Uma concepção de agroindústria rural de pequeno porte, Consultado em abril de 2013. http://www.journal.ufsc.br/index.php/revistacfh/article/view/25195

109. ALMEIDA, F. 0 bom negócio da sustentabilidade. Rio de Janeiro. Nova Fronteira, 2002. 110. Fernando Almeida. Experiencias Empresariais e Sustentabilidadem Elsevier Campus, 2012.

111. RODRIGUES,M.A.et.al.Sustainable developmentand sustainability of competitive advantage: a dynamic and sustainable view of the firm. Creativity E Innovation Management Journal, Setembro/2002.

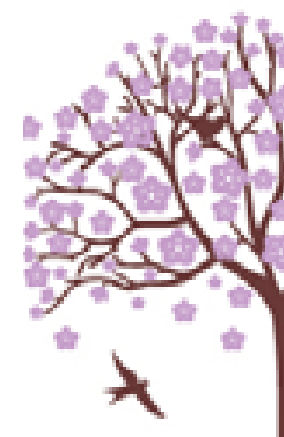


112. VASCONCELOS, M. A. S.; GARCIA, M. E. Fundamentos de Economia, 1a edição 8 ${ }^{\underline{a}}$ tiragem, Conceito de Economia p. 1-2, Saraiva, 2001.

113. KRONEMBERGER, D. M. P, CARVALHO, C. N. JUNIOR J.C. Indicador de Sustentabilidade em Pequenas Bacias Hodrográficas: Uma aplicação do "Barômetro da Sustentabilidade" A Bacia do Jurumirim (Angra dos Reis/RJ), Geochim Brasil, v. 18, p. 86-98, 2004.

114. Marzall, K. Almeida, J. Indicadores de Sustentabilidade para Agroecossistemas: Estado da arte, limites e potencialidades de uma nova ferramenta $\mathrm{p} \backslash \backslash \backslash \backslash \backslash$ ara avaliar o desenvolvimento sustentável. Cadernos de Ciencia \& Tenologia, Brasilia v.17 p. 41-59 - 2003.

115. TAYARA, F. RIBEIRO H. Modelos de Indicadores de Sustentabilidade: síntese e avaliação crítica das principais experiências, Saúde e Sociedade, v.15, p. 84-85, 2006.

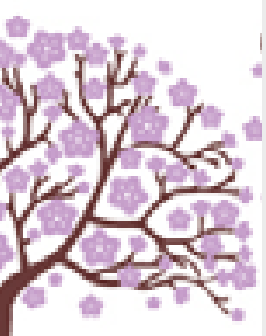

116. XXVIII ENCONTRO NACIONAL DE ENGENHARIA DE PRODUÇÃO - A integração de cadeias produtivas com a abordagem da manufatura sustentável Rio de Janeiro, RJ, Brasil, 2008.

117. VAN, B. H. M. - Indicadores de Sustentabilidade: Uma Análise Comparativa. 1ํ Edição. Rio de Janeiro. Editora FGV - 2005.
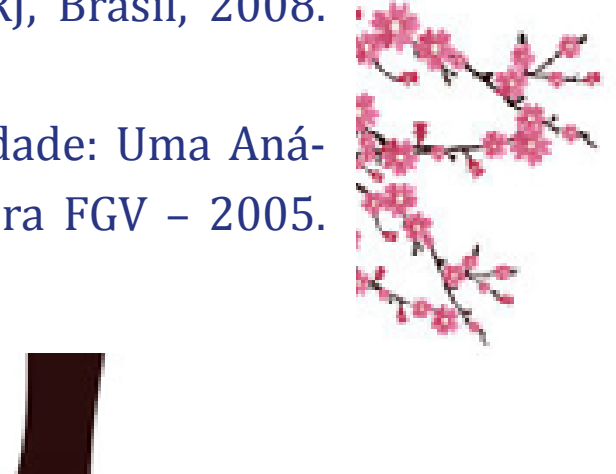


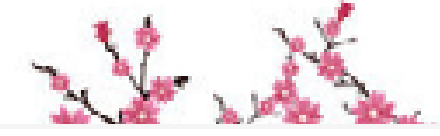

118. XV Encontro Anual da Associação Brasileira de Psicologia e - Medicina Comportamental, Indicadores de Sustentabilidade e Desenvolvimento; Contribuições da Análise do Comportamento, 2007.

119. RABELO, L. S.; LIMA, P. V. P. S. Indicadores de Sustentabilidade: a possibilidade da mensuração do desenvolvimento sustentável, REDE Revista eletrônica do Prodema, Fortaleza, v.1, p. 55-76, 2007.

* 120. Lourenço, M. S. Questões Técnicas na elaboração de Indicadores de Sustentabilidade. Consultado em abril de 2013. http://www. unifae.br/publicacoes/pdf/sustentabilidade/marcus_lorenco.pdf

162

121. Paulista, G.; Varvakis, G. Filho, G. M. Espaço Emocional e Indicadores de Sustentabilidade, Ambiente \& Sociedade, Campinas, v. 11, p. 185-200, 2008.

122. VAN, B.; HANS, M. Indicadores de sustentabilidade: uma análise comparativa,1ed.RiodeJaneiro FundaçãoGetúlioVargas,p.156,2005.

123. CÂMARA DA INDÚSTRIA DA CONSTRUÇÃO - Guia da Sustentabilidade na Construção - Belo Horizonte - FIEMG - p. 60, 2008.

124. DIAS, G. F. Educação Ambiental - princípios e práticas, Gaia, São Paulo, 9 ed, 2004.

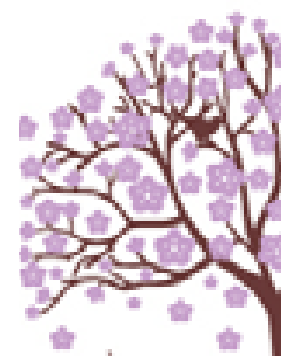


125. BARATA, M. M. L. A gestão ambiental no setor público: uma questão de relevância social e econômica. Consultado em abril de 2013. http://www.scielosp.org/pdf/csc/v12n1/15.pdf.

126. IBAMA/UNESCO, Instituto Brasileiro do Meio Ambiente e dos Recursos Naturais Renováveis. Organização das Nações Unidas. Educação para um futuro sustentável: uma visão transdisciplinar para uma ação compartilhada. Disertação de Mestrado. Brasília, 1999. Consultado em abril de 2013.http://homologa. ambiente.sp.gov.br/EA/adm/admarqs/FuturoSustentavel.pdf.

127. FREIRE, P. Conscientização.,São Paulo, Cortez \& Moraes, 1992.

128. JACOBI, P. Educação ambiental, cidadania e sustentabilidade. Cadernos de Pesquisa, v. 118, p. 189-205, 2003.

129. MARTIRANI, L. A. Comunicação, Educação e Sustentabilidade: o novo campo da Educomunicação Sociomabiental. Sociedade Brasileira de Estudos Interdisciplinares da Comunicação - XXXI Congresso Brasileiro de Ciências da Comunicação, 2008.

130. PhILIPPI, J.R. A.; PELICIONI, M. C. F. Bases Políticas, Conceituais, Filosóficas e Ideológicas da Educação Ambiental, Educação Ambiental e Sustentabilidade, Manole, p. 3-14, 2005.

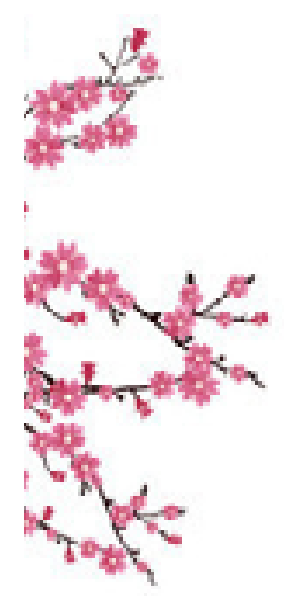




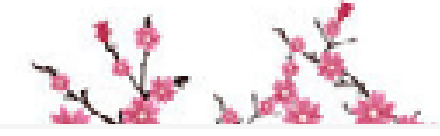

131. SILVA, A. M.; TAGLIEBER, J. E. A escola como cen* tro irradiador da Educação Ambiental. Encontro de Pesquisa em Educação Ambiental em Práticas de Pesquisa em Educação Ambiental, Ribeirão Preto: FFCLRP/USP, v. 3, 2005.

132. DIAS, G. F. Educação ambiental - princípios e práticas, Gaia, ed. 9, São Paulo, 2004.

* 133. TAGlieber, J. E.; SILVA, A. M. A escola como centro irradiador da Educação Ambiental. In: GUERRA, A. F. S.; TAGLIEBER, J. E. (org.) Educação Ambiental: fundamentos, práticas e desafios. 1 ed.,Univali, p. 197- 213, 2007.

134. GADOTTI, M. Educação para o Desenvolvimento Sustentável: o que precisamos aprender para salvar o planeta. Revista da FAEEBAN - Educação e contemporaneidade, v. 16, p. 69-90, 2007.

135. JACOBI, P. Educação Ambiental e o desafio da sustentabilidade sócio ambiental. Revista Mundo da Sáude, v. 30, 2006.

136. PEDRINI, A. G.; BRITO, M. I. M. S. Educação Ambiental para o desenvolvimento ou sociedade sustentável? Uma breve reflexão para a América Latina, Educação Ambiental em Ação, v.17, 2006.

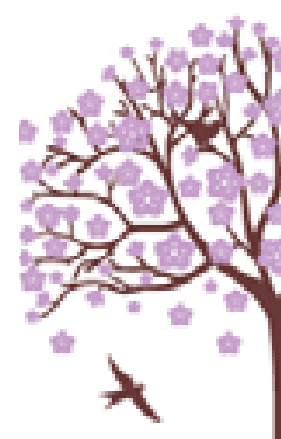


137. LUZZI, D. Educação Ambiental: Pedagogia, Política e Sociedade. In: PHILIPPI, J. R, A.; PELICIONI, M. C. F. (editors). Educação Ambiental e Sustentabilidade, São Paulo: Manole, p. 381-400, 2005.

138. CASTRO, M. L.; CANHEDO, J. R, S. G. Educação Ambiental como Instrumento de Participação. In: PHILIPPI, J. R. A.; PELICIONI, M. C. F. (editores). Educação Ambiental e Sustentabilidade. São Paulo: Manole, p. 401-412, 2005.

139. TEIXEIRA, A. C. Educação Ambiental: Caminho para a sustentabilidade. Revista Brasileira de Educação Ambiental, v. 2, p. 23-31, 2007. 140. LEFF, E. Epistemologia Ambiental, São Paulo, Editora Cortez, 2001. 141. SUAVÉ, L. Educação Ambiental e Desenvolvimento Sustentável: uma análise complexa, Revista de Educação Pública, v.10, 1997.

142. HERNÁNDEZ, M. C. P.; POCHIROLLI, O. 0 papel da educação para o desenvolvimento sustentável. Terceiro Seminário sobre Sustentabilidade da UNIFAE. As dimensões humanas das mudanças ambientais, so o ponto-de-vista do pensamento complexo, 2008.

143. LIMA,G.F.C.O discurso dasustentabilidade esuas implicações

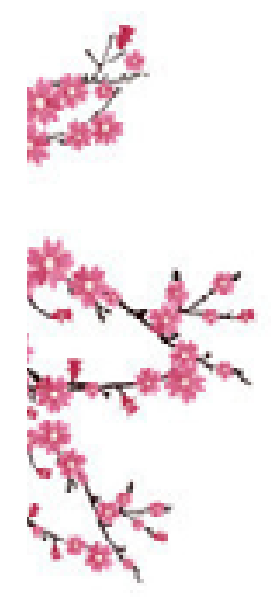




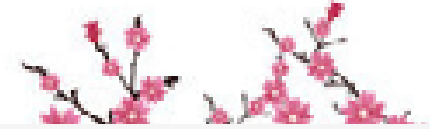

para a educação, Ambiente \& Sociedade, NEPAM/UNICAMP, v. 6, 2003.

144. NUNES, I. R. A avaliação do ciclo de vida como ferramenta para a educação ambiental: o uso da redução do desperdício e do aumento da produtividade como indicadores. (Dissertação de mestrado em Tecnologia Nuclear). Instituto de Pesquisas Energéticas e Nucleares (IPEN), Universidade de São Paulo, São Paulo, 2009.

145. AMBIENTE BRASIL entrevista com a organizadora do I Simpósio Brasileiro de Psicologia Ambiental, psicóloga Luana Cristina Beal, Consultado em abril de 2013. http://portal.cefet-rj. br/files/extensao/outros/livro_sem_ext_2011.pdf\#page $=44$.

146. CAPRA, F. Alfabetização Ecológica. Editora Cultrix, 2007.

147. http://mercadoetico.terra.com.br/arquivo/psicologia-e-fundamental-na-queso-climatica/. Consultado em março de 2013.

148. TRIGUEIRO, A. Mundo Sustentável: abrindo espaço na mídia para um planeta em transformação, Editora Globo, p. 264, 2005.

149. Efeitos da Poluição do Ar. consultado em outubro 2011 e março de 2013. http://www.universoambiental.com.br/AR/Ar_Controle7.htm.

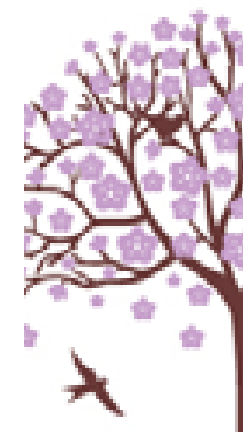


150. Annelise Engel Gerbase e Camila Reis de Oliveira. Reciclagem do Lixo de Informática: Uma Oportunidade para a Química, Química Nova, Vol. 35, p.1486-1492, 2012.

151. AMBIENTE BRASIL. Energia Geotérmica. Consultado em abril de 2013. http://books.google.com.br/ books?hl=ptPT\&lr=\&id=brw6Px76Zf8C\&oi=fnd\&pg=PA66\&d$q=158 . \% 09 A M B I E N T E+B R A S I L .+E n e r g i a+G e o t e ́ r m i c a \& o t s$.

152. Sobrinho, L. L. P.; SILVA, R. Consumo e sustentabilidade. Consulado em abril de 2013. http://www.balcaodoconsumidor.com. $\mathrm{br} /$ upload/conteudo_dinamico_arq/13_arq-13.pdf\#page $=30$.

153. WELSH, C. N.; HERREMANS, I. M. Tread softly: adopting environmental management in the start-up phase. Journal of Organizational Change Management. v. 11, p. 145-155, 1998.

154. STROBEL.JS. E. SELIG, P. M.; CORAL, E. Indicadores de sustentabilidade: umaanalise corporativa. Anais doXXVIIIEnANPAD, v.1,p.1-6,2004.

155. SUSTENTABILIDADE, São Paulo, ed. Abril, 10a edi. 2009. Consultado e abril de 2013. http://scholar.google.com.br/scholar?q=\%09SUSTENTABILIDADE\%2C+S\%C3\%A3o+Paulo\%2C+ed.+Abril.
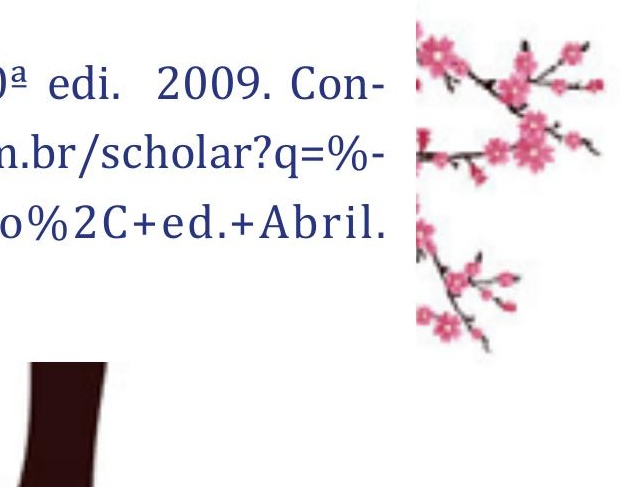